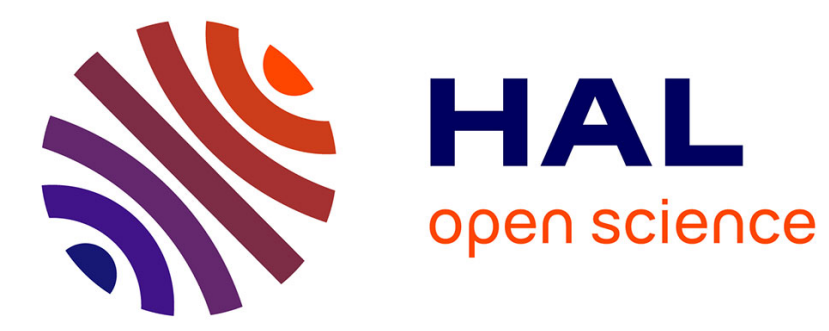

\title{
Metal and metalloid determination in biodiesel and bioethanol
}

Raquel Sánchez, Carlos Sánchez, Charles-Philippe Lienemann, José-Luis Todolí

\section{- To cite this version:}

Raquel Sánchez, Carlos Sánchez, Charles-Philippe Lienemann, José-Luis Todolí. Metal and metalloid determination in biodiesel and bioethanol. Journal of Analytical Atomic Spectrometry, 2015, 30 (1), pp.64 - 101. 10.1039/C4JA00202D . hal-01105222

\section{HAL Id: hal-01105222 \\ https://hal.science/hal-01105222}

Submitted on 20 Jan 2015

HAL is a multi-disciplinary open access archive for the deposit and dissemination of scientific research documents, whether they are published or not. The documents may come from teaching and research institutions in France or abroad, or from public or private research centers.
L'archive ouverte pluridisciplinaire HAL, est destinée au dépôt et à la diffusion de documents scientifiques de niveau recherche, publiés ou non, émanant des établissements d'enseignement et de recherche français ou étrangers, des laboratoires publics ou privés. 


\section{Metal and metalloid determination in biodiesel and bioethanol}

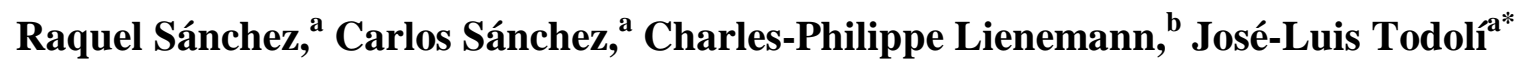

${ }^{a}$ Department of Analytical Chemistry, Nutrition and Food Sciences, P.O. Box 99, 03080, Alicante, Spain

b IFP Energies Nouvelles, Rond-point de l'échangeur de Solaize, BP 3, F-69360 Solaize France 


\begin{abstract}
Biofuels quality control involves the determination of metal and metalloid content. These species play a very important role because they may modify the efficiency of the biofuel production as well as the stability of these products. Furthermore, some metals are toxic and generate environmental concerns whereas others are used as additives. Normally, products such as biodiesel and bioethanol are mixed with fosil conventional fuels (diesel and gasoline, respectively). Therefore, metals come from the raw product employed for biofuel production (seeds, sugars...) as well as from the production and stocking process or even from the added fuels. The determination of the final metal and metalloid concentration in biofuels is a challenging subject because of several reasons. On the one hand, their content is usually low (i.e., from several $\mathrm{ng} / \mathrm{ml}$ to $\mu \mathrm{g} / \mathrm{ml}$ ) and, hence, sensitive techniques should be used. Besides all this, organic complex matrices make the calibration to be more difficult and degrade the accuracy of the determination. Several approaches have been evaluated to carry out this kind of analysis going from spectrochemical to electroanalytical techniques. Within the first group, Inductively Coupled Plasma Optical Emission Spectroscopy (ICP-OES) and Mass Spectrometry (ICP-MS) are often employed together with Atomic Absoption methods. The different procedures applied will be discussed in the present review emphasizing the most widely employed ones. On this subject fundamental as well as applied studies related with the biofuels analysis through ICP-OES and ICP-MS will be shown to illustrate the current difficulties associated to these determinations. Comments regarding to the possible solutions proposed to overcome the drawbacks encountered will be made.
\end{abstract}


1. General Introduction

2. Fundamental studies

2.1. Drop size distribution

2.2. Aerosol transport

2.3. Plasma effects

3. Biodiesel

3.1. Synthesis and importance of metal determination

3.2. Analysis by ICP techniques

3.2.1. Conventional sample introduction systems and electrothermal vaporization

3.2.2. Spectral and non spectral interferences

3.2.3. Isotopic analysis

3.3. Analysis by additional techniques

3.4. Comparison among techniques

4. Bioethanol

4.1.Synthesis and importance of metal determination

4.2.Analysis by ICP techniques

4.2.1. Conventional sample introduction systems and electrothermal vaporization

4.2.2. Spectral and non spectral interferences

4.2.3. Speciation

4.3.Analysis by other techniques

4.4.Comparison among techniques.

5. Conclusions

6. Literature 


\section{General Introduction}

Nowadays, the interest in the development of energy sources alternative to fossil fuels has increased significantly. This demand has driven in international directives promoting the use of renewable energy sources with environmental benefits. The most used promising and developed biofuels are bioethanol and biodiesel. Considerable research focused in new raw material and procedure has been developed. Moreover, the demand of new biofuel is strongly associated with the development of new methods to assure the quality of the final products. In this sense, the determination of metals and metalloids plays a fundamental role.

The quantification of metals and metalloids in bioethanol and biodiesel shows many difficulties: (i) they are present at very low concentrations $\left(\mu \mathrm{g} \mathrm{L}^{-1}\right)$; (ii) there are limited certified reference materials; (iii) normally, the bioethanol commercially available has up to $4 \%$ of water so it exists in a large variety of matrices; (iv) different sources of raw material can be employed affecting the characteristics of the final product; and, (v) bioethanol and biodiesel contain around 300 different organic compounds depending on its origin and treatment $^{1,2}$. For these reasons, a sensitive and accurate technique is required to carry out the determination of metals and metalloids in this type of samples. In addition, it is necessary to develop analytical techniques to remove matrix effects due to the high number of matrices that we can found marketed under the name biodiesel and bioethanol.

From the above mentioned, it is obvious that sensitive techniques are required to carry out the determination of metals and metalloids in this type of samples. In addition, it is necessary to develop analytical methods able to compensate for matrix effects due to large variety of matrices found in bioethanol and biodiesel samples. Inductively Coupled Plasma Optical Emission Spectrometry (ICP-OES) and Mass Spectrometry (ICP-MS) appear as the most appropriate techniques to perform elemental determinations in biofuels, although 
alternative techniques have also been applied for this purpose. The fundamentals, applications and latter developments of biodiesel and bioethanol products analysis are revisited in the present work.

\section{Fundamental studies}

In order to understand the phenomena occurring when organic samples such as biodiesel and bioethanol are introduced into an ICP-OES, fundamental studies are required. This kind of samples may interfere on each step of the sample analysis from the aerosol production to the signal recording. However, biofuels also present some particular problems that difficult their analysis through ICP techniques. Thus, for example, due to the high viscosity of biodiesel samples, a pretreatment step of the sample is usually required. The dilution with a proper solvent is the most extended procedure. The solvents generally

employed are ethanol, kerosene and xylene. ${ }^{3-5}$ As a result, a complex mixture is obtained. Bioethanol, in turn, may contain variable proportions of water, propanol, butanol and other low molecular weight alcohols ${ }^{1}$. Therefore, the physico-chemical properties of the sample will change thus causing an intensification of the matrix effects.

\subsection{Aerosol generation}

When a pneumatic nebulizer is used to generate the aerosol, the solution physical properties affect the characteristics of the produced mist. For this kind of nebulization devices, the most important properties are the surface tension and the viscosity. Organic samples, such as those included in the terms bioethanol and biodiesel, have a quite wide range of viscosities and surface tension values. Table 1 summarizes the density and viscosity for four representative 
FAME and biodiesel samples. Moreover, two synthetic samples usually prepared to simulate a blank solution are also included. In this case, the portion of biodiesel sample was replaced by an Element Stock Oil (75 Viscosity, Conostan, Ponca City, Oklahoma, USA). As it may be observed, viscosity is different according to the particular solution considered.

Table 1. Density and viscosity for the different samples.

\begin{tabular}{|c|c|c|}
\hline Sample & Viscosity (cP) & Density $\left(\mathrm{g} \mathrm{cm}^{-3}\right)$ \\
\hline FAME - Xylene 1:1 & 2.5 & 0.83 \\
\hline Stock oil - Xylene 1:1 & 1.5 & 0.84 \\
\hline FAME -Kerosene 1:1 & 3.2 & 0.84 \\
\hline Stock oil - Kerosene 1:1 & 1.9 & 0.84 \\
\hline Xylene & 0.6 & 0.85 \\
\hline Biodiesel & 5.1 & 0.84 \\
\hline Xylene : Biodiesel 1:10 & 0.7 & 0.85 \\
\hline
\end{tabular}

In order to evaluate the influence of solution physical properties on the nebulizer performance, the aerosols produced in a first instance (i.e., primary aerosols) can be measured. Farino and Browner ${ }^{6}$ studied the effect of the sample surface tension on the aerosol 
properties. As this physical property decreases, the energy required to generate a droplet from the solution bulk goes down. In addition, in solvents with low surface tension, the waves generated on the liquid surface have a short wavelength and the gas penetrates easily into the liquid bulk. As a result, the liquid and gas interaction becomes highly efficient, thus favouring aerosols with low droplet diameters. For example, when a pneumatic concentric nebulizer is operated under typical conditions (i.e., $1 \mathrm{~mL} \mathrm{~min}^{-1}$ liquid flow rate and $0.7 \mathrm{~L} \mathrm{~min}^{-1}$ nebulizer gas flow rate) the median of the aerosol volume drop size distribution $\left(\mathrm{D}_{50}\right)$ for primary aerosols are 17 and $11 \mu \mathrm{m}$ for water and ethanol, respectively. It is worth to mention that surface tension for ethanol $\left(21.4 \mathrm{dyn}^{-1}\right)$ is approximately three times lower than for water, whereas both solvents present similar viscosity values. ${ }^{7}$

Regarding viscosity, as Sharp studied, the instabilities generated on the liquid surface during the nebulization event are attenuated for liquids with high values of this physical property, ${ }^{8}$ thus promoting the generation of coarse aerosols. The primary aerosol characteristics differ according to the samples viscosity that, as Table 1 reveals, is a function of the solvent employed to dilute the sample. Thus, for instance, for a pneumatic concentric nebulizer, when xylene is used to dilute the samples, all the primary aerosol liquid volume is contained in droplets with diameters below $13 \mu \mathrm{m}$, whereas this maximum diameter increases up to $17 \mu \mathrm{m}$ when the employed solvent is kerosene.

In the case of biodiesel, the $\mathrm{D}_{50}$ takes values of 11,63 and $23 \mu \mathrm{m}$ for xylene, biodiesel and the 1:10 diluted biodiesel, respectively. As expected, compounds with low viscosity favor the production of fine aerosols. ${ }^{8,9}$ It is also worth to notice the poor nebulization yield observed for a pure biodiesel sample. Due to the high $\mathrm{D}_{50}$ value, the sensitivity finally obtained will be extremely low. For this reason, the solution often proposed to carry out the analysis is to dilute the sample. 
In the case of bioethanol, the final sample composition may vary as a function of several factors among them the water content or the additives present. This fact is illustrated in Figure 1 in which the Sauter mean diameter, $\mathrm{D}_{3,2}$, significantly changes as a function of the sample considered.

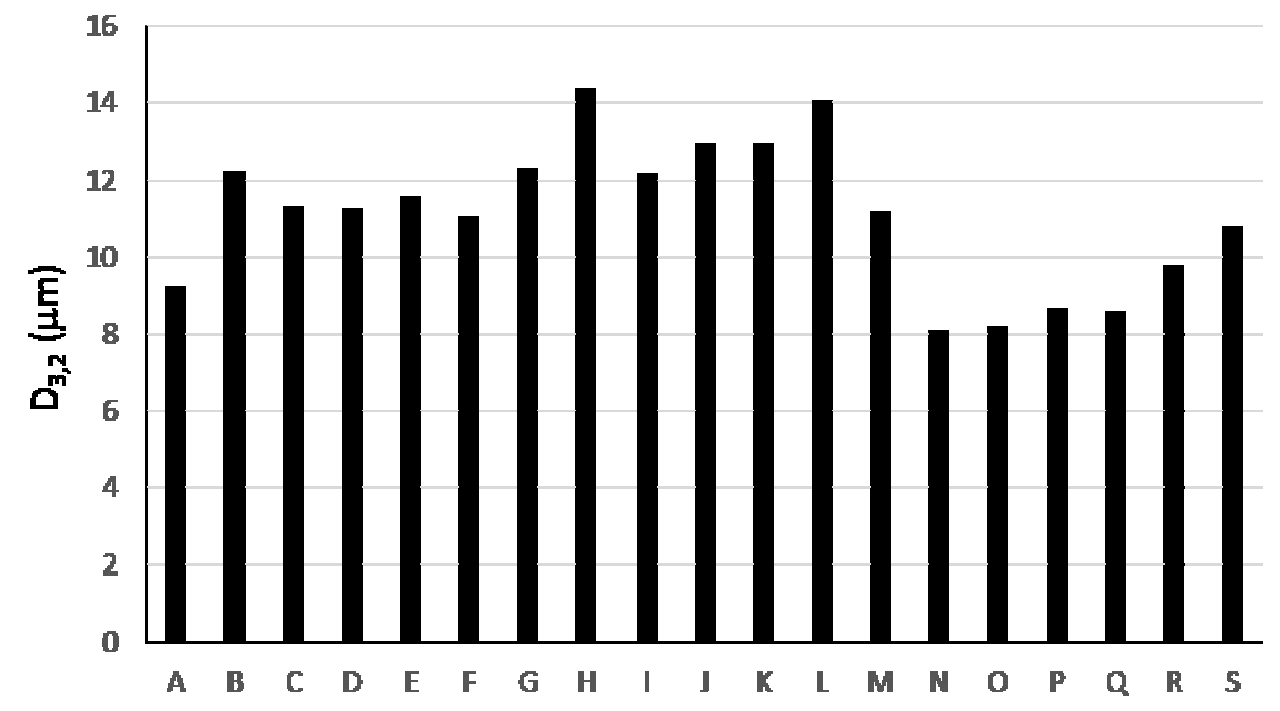

Figure 1. Sauter mean diameter $\left(D_{3,2}\right)$ for primary aerosols generated by a conventional pneumatic concentric nebulizer working with several bioethanol samples.

\subsection{Aerosol transport}

Once the aerosol is generated, several phenomena take place inside the spray chamber that lead to a modification in its characteristics. These are the so-called aerosol transport phenomena and they are responsible for analyte losses inside the spray chamber. The most influencing events are: (i) solvent evaporation; (ii) droplet coalescence, and; (iii) droplet inertial impacts. The major changes in the primary aerosol characteristics are caused by the nebulizer gas flow rate and the design of the spray chamber. ${ }^{10}$ However, the primary aerosol 
characteristics together with sample physical properties, mainly density and volatility, affect the extent of all these processes.

In the case of organic saamples, the solvent volatility is the most relevant property precluding the mass of solution delivered to the plasma. The solvent evaporation takes place mostly just after the aerosol generation until the gas becomes saturated in solvent. The high solvent volatility together with the fineness of the organic aerosols contribute to an enhancement in the mass of analyte and solvent reaching the plasma. ${ }^{11,12}$ Under these circumstances, nebulization conditions (liquid and gas flow rates) have a more determining effect for organic solvents than for aqueous solutions. Thus, for volatile solvents, the solvent transport efficiency may reach values close to $100 \%$. Therefore, the selection of the appropriate experimental conditions is a more challenging issue for the formers. ${ }^{13}$

The fineness of the aerosol leaving the spray chamber (tertiary aerosol) and the mass of solvent and analyte transported to the plasma are indicators of the quality of the primary aerosol transport. In fact, the drop size distribution of the tertiary aerosol is proposed by several authors as the property that plays a major role in terms of plasma thermal state because it determines the amount of energy required to vaporize the matrix. ${ }^{14}$ On this subject, finer aerosols are found when working with $50 \%(\mathrm{v} / \mathrm{v})$ ethanol - water mixtures than for water alone. These results are independent of the spray chamber considered. ${ }^{15} \mathrm{~A}$ stirred tank methodology has been used to thoroughly study the effect on increasing the ethanol concentration on the characteristics of the aerosols leaving the spray chamber. ${ }^{16}$ The results proved that the median of the tertiary aerosol volume drop size distribution decreased significantly as the concentration of this alcohol went up to $5 \%$. Then the decrease in this statistical parameter with the ethanol content became less pronounced. The intensification of the solvent evaporation inside the spray chamber and the fineness of the generated aerosols as the ethanol proportion grows appear to be the dominating phenomena. 
The evolution of drop diameter versus time as a result of the solvent evaporation is a function of the so-called evaporation factor ${ }^{12}$ which depends directly on the vapor diffusion coefficient, solvent surface tension, the saturated vapor pressure and the molecular weight and inversely on the solvent density, the gas constant and the temperature. As Boorn et al ${ }^{17}$ reported, the solvent evaporation factor for ethanol is about three times higher than evaporation factor for water $\left(E_{\text {ethanol }}=45.6 \mu \mathrm{m}^{3} / \mathrm{s}\right.$ vs $\left.E_{\text {water }}=13.1 \mu \mathrm{m}^{3} / \mathrm{s}\right)$.

As a result of the finer aerosols and the higher evaporation factor, for a pneumatic nebulizer adapted to a double pass spray chamber, the total mass of solvent transport rate leaving the chamber was 6 times higher for ethanol as compared to water. Note that the relative volatility values were 0.1 and 0.7 for water and ethanol, respectively. ${ }^{7}$ As the solvent evaporation becomes more significant and finer aerosols are generated, droplets decrease their diameters and they have more chance to be transported through the spray chamber. The net result is an increase in the analyte transport rate. In the particular case of ethanol samples, this parameter was about five times higher than for water.

\subsection{Plasma effects.}

As for organic solvents, when carrying out the analysis of bioethanol or biodiesel samples, plasma effects should be carefully considered. These effects are related with the plasma energy consumed for the solvent vaporization and dissociation. Obviously, the operating nebulization conditions (i.e., the liquid flow rate and nebulizer gas flow rate) play a fundamental role, because they dictate the aerosol mass reaching the plasma. For instance, it is sometimes advisable to lower both variables so as to reduce the solvent plasma load thus increasing the residence time of the analyte in the plasma. ${ }^{18}$ Nevertheless, if these variables (especially the nebulizer gas flow rate) are excessively low, the analyte mass transported 
towards the plasma may be too low thus resulting detrimental from the point of view of sensitivity. Plasma degradation caused by the presence of bioethanol or biodiesel also become less pronounced at high R.F. power values. Under these conditions, sensitivities may be higher for organic samples than for aqueous matrices. In contrast, if plasma effects are not taken into consideration, organic solvents may cause a decrease in the sensitivity. ${ }^{19}$ Note that all these phenomena are indeed drawbacks, because the main goal of the ICP determination is to render sensitivity unchanged irrespectively of the sample nature. Only in this way, good accuracy is achieved.

Several studies have been conducted in order to try to understand the effects caused by the presence of an organic matrix on the plasma performance. When an organic sample (e.g. ethanol, biodiesel) is introduced into the ICP, specific effects take place such as: (i) molecular emission of solvent pyrolysis products; (ii) modifications in the plasma geometry; (iii) generation of vortex in the plasma; (iv) changes in electron number density, hydrogen density and excitation temperature; and, $(v)$ formation of carbon or soot deposits somewhere in the spectrometer.

\section{Molecular emission of solvent pyrolysis products}

The incomplete combustion of organic solvents yields some molecular species, not observed in the case of aqueous solutions, that are excited in the plasma. The molecular emission bands can spectrally interfere on the analytical emission. In ICP-OES, Boorn et al. ${ }^{17}$ observed a green $\mathrm{C}_{2}$ emission zone around the outside of the plasma. The instability of the plasma when ethanol and other alcohols reached it resulted from a gradual quenching of the luminous plasma core from beneath the coil, which finally reached the core region causing the plasma extinction. ${ }^{17}$ Cyanide, carbon monoxide and diatomic carbon are also frequently generated. Cyanide radical $(410-430 \mathrm{~nm})$ and diatomic carbon $(450-520 \mathrm{~nm})$ emissions are produced in 
the boundary regions of the discharge whereas atomic carbon emission is observed in the plasma region. ${ }^{20}$ These emissions contribute to increase the background level. Weir et al. ${ }^{21}$ observed that cyanide emission was very important in the case of methanol and they concluded that these results could be extrapolated to ethanol. In the same study, they observed that diatomic carbon emission for alcohols was lower than for other organic solvents. This was because of the competition existing between diatomic carbon and monoxide carbon formation. Note that the $\mathrm{O} / \mathrm{C}$ ratio in short alcohols is higher than for other solvents and that the bond energy for $\mathrm{CO}$ is higher than for $\mathrm{C}_{2}$. The intensity of these emissions depends on the plasma observation height. ${ }^{10,14,17,22}$ Thus, atomic line from carbon decreased with observation height whereas cyanide emission showed an opposite behavior. Emission from diatomic carbon shows more complex behavior. $^{21}$

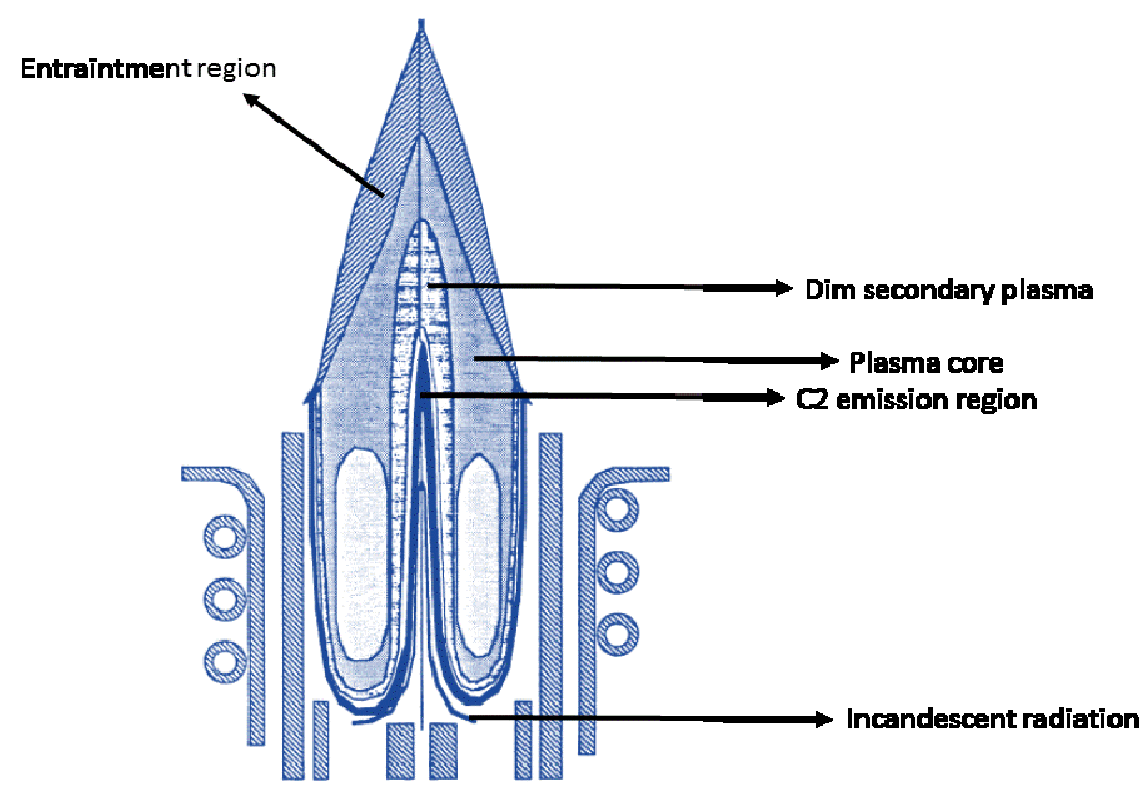

Figure 2. Scheme of a plasma loaded with an organic solvent highlighting the zones of production of pyrolysis products (adapted from ref. ${ }^{21}$ ). 
The plasma geometry may undergo modifications when an organic solvent reaches it. Weir and Blades ${ }^{21}$ verified that in presence of organic solvents the plasma moved downstream and its central channel dilated. They also observed that these effects became more significant as the solvent load increased. This fact revealed that ethanol loading could drastically modify the energy available at the plasma central channel. As a consequence, aerosol desolvation, vaporization, analyte atomization, ionization and excitation were severely affected.

The introduction of an organic solvent may increase the thermal conductivity hence accelerating the heat conduction away from the plasma. As a result, the peripheral zones of the plasma cool rapidly thus causing a reduction in the plasma volume. This is the so-called plasma thermal pinch and it can cause a change in the plasma temperature profile. A significant thermal pinch effect was observed when introducing methanol in the plasma that could be extrapolated to ethanol ${ }^{21}$ and ethanol-water solutions. ${ }^{14,23}$

\section{Vortex generation in the plasma}

One of the most important plasma fluctuations is a result of vortex shedding beyond the exit of the torch. Weir and Blades ${ }^{24}$ proved that vortex are present in ICP and this phenomenon causes modulation of emission. They observed that the vortex shedding frequency depended on the solvent and the solvent plasma load. ${ }^{21,24}$

\section{Changes in electron number density, hydrogen density and excitation temperature}

Studies dealing with plasma effects reveal that the presence of an organic solvent causes a decrease in excitation temperature ${ }^{25,19,17}$ as well as in the electron number density. ${ }^{26}$ Thus, for the analysis of organic samples the R.F. power must be increased by approximately $0.5 \mathrm{~kW}$ to simulate the temperatures reached in an aqueous matrix. ${ }^{26}$ Moreover, the sample introduction 
system plays a role of capital importance conditioning the effect caused by the organic compounds on the characteristics of the atomization and/or ionization cell. . $^{25,19,24,27}$

However, it was found that when ethanol reached the plasma, hydrogen concentration increased. Mc Crindle et al. ${ }^{10}$ proposed the following mechanism for the thermal decomposition of ethanol in the plasma:

$$
\begin{aligned}
2 \mathrm{C}_{2} \mathrm{H}_{5} \mathrm{OH}+7 \mathrm{O}_{2} & \rightarrow 4 \mathrm{CO}+12 \mathrm{OH} \\
\mathrm{CO}+\mathrm{OH} & \rightarrow \mathrm{CO}_{2}+\mathrm{H}
\end{aligned}
$$

As a result of the breakdown of hydrogen coming from ethanol free electrons were generated thus giving rise to an increase in the electron number density $\left(\mathrm{n}_{\mathrm{e}}\right)$. The consumption of the $\mathrm{OH}$ radical in the second step of this mechanism explained why when alcohols were aspirated, the $\mathrm{OH}$ band became weak. ${ }^{17}$

McCrindle et al. ${ }^{10}$ reported a $\mathrm{n}_{\mathrm{e}}$ increase when ethanol concentration went from $0 \%$ to $25 \%$. The last content was the maximum concentration tolerated by the plasma before its extinction. In agreement with this, for $25 \%$ ethanol concentration the $\mathrm{H}_{\alpha}$ emission was four times higher than for pure water. These authors also reported that when pure water reached the plasma $\mathrm{n}_{\mathrm{e}}$ was maximum at $5 \mathrm{~mm}$ from the center of the torch but for a $25 \%$ ethanol solution this radial maximum was located at the center of the torch. ${ }^{10}$ In another study, the same authors indicated that the electron number density in the plasma central channel increased almost three times for ethanol, while at $\mathrm{z}=5 \mathrm{~mm} \mathrm{n} \mathrm{n}_{\mathrm{e}}$ was two times higher than for pure water. ${ }^{22}$ Working with a more robust plasma the maximum value of electron density was also obtained for $25 \%$ of ethanol although the maximum intensity for $\mathrm{H}_{\alpha}$ line was obtained for $60 \%$ of ethanol. ${ }^{14}$

Of course, hydrogen emission and electron density depended on the operating conditions. As it has been reported, the effect of ethanol concentration on $\mathrm{H}$ emission intensity is more pronounced at low than at high RF power. At $1.02 \mathrm{~kW}$ the emission signal of 
hydrogen $(434.05 \mathrm{~nm})$ for $10 \%$ of ethanol was around 3 times higher than that obtained for water while at $1.36 \mathrm{~kW}$ this improvement factor was only 2 times. $^{23}$

The viewing position also affects the hydrogen intensity and, hence, $\mathrm{n}_{\mathrm{e}}$. In general terms when viewing height is increased the hydrogen intensity decreases due to the short live of atomic or ionic hydrogen in the plasma. A 5 times decrease in the $\mathrm{H}_{\alpha}$ emission intensity has been reported when the viewing height changed from 2 to $10 \mathrm{~mm}$ above the load coil aspirating $15 \%$ ethanol solution. ${ }^{14}$

Besides electron number density, plasma excitation temperature modifies when an organic solvent is delivered to the excitation cell. Several authors reported decreases in this parameter as compared to aqueous solutions..$^{17,19,22,23,26,28-30}$ By a proper selection of the plasma operating conditions, it was found that pure ethanol solutions only caused a $300 \mathrm{~K}$ decrease in the plasma temperature with respect to plain water standards. ${ }^{7}$ However, Benli ${ }^{31}$ reported a maximum pattern in the excitation temperature as the ethanol content went up. In agreement with all these studies, McCrindle et al. found that an increase in ethanol concentration caused an initial increase in the excitation temperature reaching a maximum at $15 \%(\mathrm{v} / \mathrm{v})$, then it decreased with further increases in ethanol concentration. The difference in temperature at $15 \mathrm{~mm}$ above the load coil between pure water and 5\% ethanol was $600 \mathrm{~K}$. For $25 \%$ ethanol the temperature was similar to that obtained for pure water. ${ }^{23}$

A change in the hydrogen content can be claimed in order to try to explain the eventual increases in plasma fundamental parameters found when introducing ethanol. The effect of adding molecular hydrogen to the plasma has been previously described and its beneficial role on both $n_{e}$ and excitation temperature has been demonstrated..$^{23,26,32-35}$ Walters et $a l .{ }^{34}$ reported that ionization temperature increased by $400 \mathrm{~K}$ upon the addition of $2 \%$ of hydrogen. On the other hand, Ebdon et al. ${ }^{36}$ found a $1700 \mathrm{~K}$ increase in the rotational temperature and Murillo et al. ${ }^{35}$ observed an increase of $1000 \mathrm{~K}$ in the "soft" excitation 
temperature. Visser et $a l .{ }^{32}$ also obtained a high excitation temperature (c.a., 14,700 K) adding to the plasma $4 \%$ of hydrogen. In the case of ethanol increases in 600 and $1160 \mathrm{~K}$ have been reported for $5 \%$ and $15 \%$ of this alcohol, respectively. ${ }^{23}$ The increase in hydrogen generation and, hence, the rise in the plasma thermal conductivity, in presence of ethanol with respect to water are based on the fact that the energy requirements to induce its dissociation are very low in comparison with those for water.

A parameter widely studied to monitor the plasma thermal state and its robustness is the magnesium ionic to atomic net emission intensity ratio ( $\mathrm{MgII} / \mathrm{MgI})$. According to some previous studies it has been indicated that this ratio increased with ethanol concentration as the concentration was increased up to $25 \% .^{14}$ This trend was confirmed by the experiments done with a stirred tank setup. For a less robust plasma, it was found that the $\mathrm{MgII} / \mathrm{MgI}$ ratio peaked at about $8 \%$ ethanol and then decreased. ${ }^{16}$ Possible explanations could be based on the increased plasma thermal conductivity and/or thermal pinch. Once the ethanol plasma load becomes too high, a degradation in its excitation conditions is produced.

\section{Formation of carbon or soot deposits somewhere in the spectrometer}

Finally, the formation of carbon deposits in some parts of the spectrometer, such as injector or the torch walls may degrade the plasma stability., ${ }^{4,37}$ Solvent evaporation factor can be connected with the limiting aspiration rate defined as that the maximum liquid flow allowing a stable plasma operation, with no appreciable carbon deposition on the inner torch surfaces. ${ }^{17}$ Normally, the tolerance to solvents decreases when evaporation factor increases. In these terms, ethanol shows different behavior because it has moderate evaporation rates but it causes a quick quenching in the plasma due to other effects such as solvent pyrolysis products emission effect. Similar results have been observed for several ethanol/water mixtures. In order to avoid this problem, oxygen can be added to the carrier argon stream. Oxygen can also 
added in order to prevent the carbon (soot) deposition in the sampling cone thus causing its partial blocking and reducing sensitivity. ${ }^{38,39}$ However, if too much oxygen is added in ICPMS, the cones can deteriorate and the polyatomic interferences can become more severe.

\subsection{Spectral interferences}

Spectral interferences caused by organic samples in ICP-OES are due to the solvent pyrolysis products. In presence of an organic solvent, the most abundant species in plasma are $\mathrm{C}_{2}, \mathrm{CN}$, and C. Furthermore, depending on the solvent nature, other molecules may be present such as $\mathrm{CS}, \mathrm{CH}, \mathrm{NO}$ and $\mathrm{CO}$. Thus, the spatial distribution of these molecules in the plasma precludes the measurement zone of the emission of the analyte. Figure 3 shows the evolution of the background spectrum versus the plasma observation height revealing that when an alcohol is introduced into the plasma, spectral interferences are strongest at its base. Note that the plasma operating conditions can alter the distribution of the pyrolysis products. ${ }^{40}$ Moreover, it is very important to take into account the physical form in which the solvent reaches the plasma because a large fraction of it is in vapor form. ${ }^{19}$ Pan et al. ${ }^{19}$ demonstrated that the main impact of desolvation with organic solvents is to reduce the $C_{2}$ species population in the plasma, which in turn strongly influences plasma temperatures. 


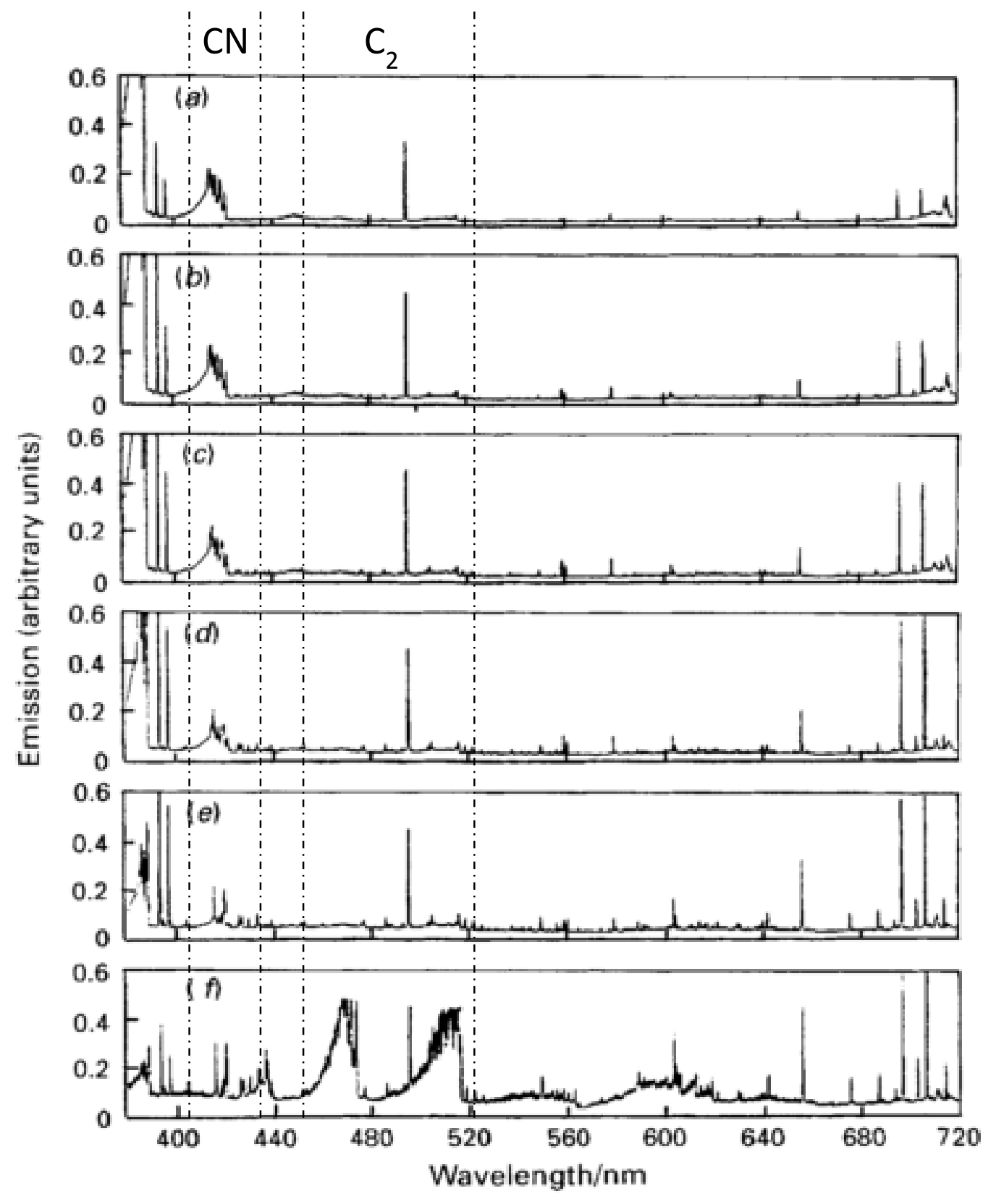

Figure 3. Spectral survey of the visible emission from de ICP loaded with methanol for several observations heights: (a) $21 \mathrm{~mm}$; (b) $18 \mathrm{~mm}$; (c) $15 \mathrm{~mm}$; (d) $12 \mathrm{~mm}$; (e) $9 \mathrm{~mm}$; (f) 6 mm. Cyanide radical (410-430 nm) and diatomic carbon $(450-520 \mathrm{~nm})$ Taken from ref. ${ }^{21}$

On the other hand, alcohols also induce ICP-MS spectral interferences. ${ }^{41-43}$ They can be explained in terms of: $(i)$ charge transfer reactions from $\mathrm{C}$ species to the analyte ions; ${ }^{44}$ (ii) enhancement of the aerosol transport efficiency through the sample introduction system; ${ }^{45}$ and (iii) shifts in the plasma zone of maximum ion density. ${ }^{46,47}$ The presence of ethanol ${ }^{48}$ can lead 
to increases in the sensitivity for some isotopes because of polyatomic interferences. Also, for this technique, the interferences could be due to the formation of pyrolysis products. ${ }^{49}$ These interferences have been extensively studied and mentioned. In order to avoid these phenomena, collision and reaction cells can be employed. Woods et.al. ${ }^{50}$ applied an ICP-MS fitted with an octopole reaction system (ORS) to the direct determination of the inorganic elements of several biodiesel samples. The ORS was used predominantly in collision mode, to eliminate polyatomic interferences. He was added to the cell as a collision gas for polyatomic interferences. The lower energy polyatomic ions were prevented from entering the quadrupole by energy discrimination. Intense plasma-based species such as ${ }^{14} \mathrm{~N}_{2}$ on ${ }^{28} \mathrm{Si},{ }^{38} \mathrm{Ar}^{1} \mathrm{H}$ on ${ }^{39} \mathrm{~K}$ and ${ }^{40} \mathrm{Ar}$ on ${ }^{40} \mathrm{Ca}$ were removed by reaction mode; in this case with $\mathrm{H}_{2}$ cell gas. Sulfur was measured removing the $\mathrm{O}_{2}$ interference by reaction with $\mathrm{Xe}$ cell gas.

\section{Biodiesel}

Nowadays, there is an increasing demand of biodiesel production. In fact, the European Directive RED 2009/28/EC ${ }^{51}$ promotes the use of substitute fuels coming from renewable, non edible origin. Among biodiesel, Fatty Acid Methyl Ester (FAME) is today one the major fuel of renewable origin available in EU 27 directly blended with diesel from fossil origin. Biodiesel is today seen as a larger term than FAME, as it is only one of the route to turn biomass to diesel fuels In the last decade, the number of papers focused on biodiesel production has increased from 31, in 2003, to 1296 in 2013.

Generally speaking, biodiesel comprises a mix of mono-alkyl esters of long chain fatty acids produced mainly by transesterification. ${ }^{52}$ However, there are four primary ways to produce biodiesel: direct use and blending, microemulsions, thermal cracking (pyrolysis) and transesterification (Table 2). ${ }^{53-58}$ 
Table 2. Main characteristics of the four primary methods for biodiesel products.

\begin{tabular}{|c|c|c|c|c|}
\hline & $\begin{array}{l}\text { Direct use with } \\
\text { or without } \\
\text { hydrogenation } \\
\text { and/or blending }\end{array}$ & Microemulsion & $\begin{array}{l}\text { Thermal } \\
\text { cracking } \\
\text { (Pyrolysis) }\end{array}$ & Transesterification \\
\hline Definition & $\begin{array}{l}\text { Direct use as } \\
\text { fuel or diesel } \\
\text { mixed with } \\
\text { biodiesel }\end{array}$ & $\begin{array}{l}\text { Microemulsions of } \\
\text { oil and ethyl } \\
\text { alcohol that } \\
\text { replace diesel. } \\
\text { Microstructures } \\
\text { with dimensions } \\
\text { generally in the } \\
\text { range 1-150 nm, } \\
\text { formed } \\
\text { spontaneously } \\
\text { from two } \\
\text { immiscible liquids }\end{array}$ & $\begin{array}{l}\text { Conversion of } \\
\text { long chain } \\
\text { saturated and } \\
\text { substances } \\
\text { (based on the } \\
\text { biomass) by } \\
\text { heat into } \\
\text { biodiesel }\end{array}$ & $\begin{array}{l}\text { Reacting an oil or fat } \\
\text { with an alcohol in } \\
\text { the presence of a } \\
\text { catalyst to form } \\
\text { esters and glycerin }\end{array}$ \\
\hline Advantages & $\begin{array}{l}\text { Liquid nature } \\
\text { High calorific } \\
\text { capacity ( } 80 \% \text { of } \\
\text { the diesel fuel) }\end{array}$ & $\begin{array}{l}\text { Good spraying } \\
\text { during } \\
\text { combustion. } \\
\text { Lower fuel }\end{array}$ & $\begin{array}{l}\text { Chemically } \\
\text { similar to } \\
\text { petroleum, } \\
\text { gasoline and }\end{array}$ & $\begin{array}{l}\text { Renewable } \\
\text { Higher cetane } \\
\text { number } \\
\text { High combustion }\end{array}$ \\
\hline
\end{tabular}




\begin{tabular}{|c|c|c|c|c|}
\hline & Renewable & viscosity & diesel & efficiency \\
\hline Drawbacks & $\begin{array}{l}\text { Higher viscosity } \\
\text { Low volatility } \\
\text { Reactivity of the } \\
\text { unsaturated } \\
\text { hydrocarbon } \\
\text { chains in the } \\
\text { absence of } \\
\text { hydrogenation }\end{array}$ & $\begin{array}{l}\text { Low cetane } \\
\text { number } \\
\text { Low-energy } \\
\text { capacity }\end{array}$ & $\begin{array}{l}\text { High energy } \\
\text { consumption } \\
\text { during } \\
\text { cracking, thus } \\
\text { increasing } \\
\text { costs }\end{array}$ & $\begin{array}{l}\text { Formation of sub- } \\
\text { product in the } \\
\text { reaction (glycerol } \\
\text { and wastewater) }\end{array}$ \\
\hline
\end{tabular}

Some others process are actually competing these four primary methods for biodiesel products, such as hydrogenation of fat toward kerosene /diesel, as well as FT synthesis. The more widespread process is actually based on transesterfication.

The production of FAME comprises three steps: (i) transesterification; (ii) separation of glycerin; and, (iii) purification of the final product.

\subsection{Synthesis and presence of metals. Importance of their determination.}

Most of the metals present in biofuel come from the raw material (e.g., seeds) or are introduced during the processing or storage of the final product. Several inorganic contaminants may occur in the raw materials, mainly due to the absorption of some minerals from the soil where the plant was grown, other sources such as pesticides and fertilizers could be considered. Seeds, commonly employed for biodiesel production, with different origin were analyzed: castor bean, cotton seed, curcas bean, fodder turnip, sunflower, soybean and 
tung. After digestion of the seed, element concentrations were determined by ICP OES $(\mathrm{Ca}$, $\mathrm{K}, \mathrm{Mg}, \mathrm{Na}$ and $\mathrm{P}$ ) and by ICP-MS, using external calibration with aqueous standard solutions. ${ }^{59}$ As it was expected the elements, whose concentration limit is regulated by international organization presented the highest concentration in the seeds. Regarding to the minor elements, $\mathrm{Al}, \mathrm{Fe}, \mathrm{Mn}$ and $\mathrm{Zn}$ concentration was strongly related to the the soil characteristics. The concentration of $\mathrm{Al}$ in the tung sample, about $200 \mu \mathrm{g} \mathrm{g}^{-1}$, was at least 4 times higher than in the other seed samples. The maximum Fe concentration was found in the fodder turnip, about $130 \mu \mathrm{g} \mathrm{g}^{-1}$. Zinc was more concentrated in the sunflower and in the castor bean samples, around $45 \mu \mathrm{g} \mathrm{g}^{-1}$. The concentrations of Mn varied from about $7 \mu \mathrm{g} \mathrm{g}^{-1}$ in tung seeds to about $27 \mu \mathrm{g} \mathrm{g}^{-1}$ for curcas bean. ${ }^{59}$ Paredes et al. has recently proposed the use of normalized ratios of mass fractions found for $\mathrm{B}, \mathrm{Fe}, \mathrm{Cu}, \mathrm{Zn}, \mathrm{P}$ and $\mathrm{S}$ as markers of the biological origin of raw materials of biodiesels of the 1 st generation. ${ }^{60}$ However, for biodiesel, a clear relation between metal fingerprint and sample origin has not been established. Pillay et $a l .{ }^{61}$ demonstrated that sharp differences could exist due to the nature of the feedstock ensuing from differences in cultivation techniques, soil conditions and plant parts used for abstracting the biofuel.

Generally speaking, transesterification compromises the reaction between fats or oils, triglycerides and an alcohol, usually methanol or ethanol, in the presence of a catalyst to produce glycerine and methyl esters or biodiesel. ${ }^{62}$ When methanol is employed the biodiesel is called FAME (fatty acid methyl esters), whereas for ethanol it is called FAEE (fatty acid ethyl ester). The catalysts employed could be classified mainly in four groups: (i) basic homogeneous; (ii) acid homogeneous; (iii) heterogeneous; and (iv) lipases. Basic catalyst are the most widely employed as they provide better reaction efficiencies. Among the basic catalysts sodium and potassium hydroxides, carbonates and sodium and potassium alkoxides, such as methoxide, epoxide, and nitrous dioxide are included. Sodium and potassium 
hydroxides are the most common basic catalysts in the industry. ${ }^{63,64}$ However, in order to be able to use these catalysts, the raw material to obtain biodiesel, must be purified so as to remove free acids. This is because the basic catalyst neutralizes free fatty acids, which may cause the formation of soaps thus promoting the formation of stable emulsions. These emulsions do not allow separation of biodiesel and glycerine affecting the purification of esters. $^{65}$ Moreover, the separation of the catalysts from the reaction products in the purification steps is technically difficult precluding the quality of the final product. ${ }^{66,4}$ The use of a suitable heterogeneous catalyst has been suggested by several research groups. The main advantage incorporated by heterogeneous catalysts is that they can be separated from the reaction products by filtration. ${ }^{62,67-88}$

In addition, it is important to note that the commercial biodiesel is a blend of the pure biodiesel (e.g. FAME, FAEE) and diesel. The European Union legislation established the maximum blend ratio in B7.5 (7.5\% biodiesel, $92.5 \%$ diesel) for technical reasons. ${ }^{89}$ Whereas, in certain non-european countries a percentage blend is mandatory. In Brazil, which has the world's most developed biofuels industry, a $25 \%$ blend is mandatory. On the other side, blends of $20 \%$ biodiesel and lower can be used in diesel equipment with no, or only minor modifications

For "pure biodiesel", metal content determination is important to ensure the quality of the final product. Some metals, especially sodium and potassium, could be incorporated to the final product during the transesterification reaction. Sodium and potassium compounds promote the formation of insoluble and abrasive solids contributing to the degradation of the engine parts or to the deposit formation in the vehicles filters. ${ }^{90-92}$ Moreover, "pure biodiesel" may contain other inorganic elements. For example some elements such as $\mathrm{Cu}, \mathrm{Cd}, \mathrm{Ni}$, etc. could be absorbed from the soil by the the plant itself. In addition, the fingerprint in terms of metal in the "industrial biodiesel" gives an indication of the environmental risk. Moreover, 
some metallic species are incorporated to the product as additives: anti-knock agents, antioxidants, burn improver, metal deactivators, anti-rust agents, anti-icing agents, upper-cylinder lubricants, and detergents. In some instances, inorganic elements could be incorporated into the product during transportation and/or production or storage. ${ }^{91,93-95}$

Finally, the presence of some metals can affect the stability of the biodiesel. ${ }^{96-98}$ Sarin et $a{ }^{99}$ studied the influence of metal contaminants on oxidation stability of Jatropha biodiesel. The induction period of the biodiesel decreased drastically with small concentrations $\left(\mathrm{mg} \mathrm{kg}^{-1}\right)$ of metal contaminants. The biodiesel exhibited oxidation stability of $3.95 \mathrm{~h}$ in Rancimat test, according to the EN $14112 .^{100}$ The biodiesel standard EN14214 ${ }^{101}$ required the oxidation stability determination at $110^{\circ} \mathrm{C}$ with a minimum induction time of $6 \mathrm{~h}$ by the Rancimat method ${ }^{100}$ whereas the ASTM standard D- $6751^{102}$ recently introduced a limit of $3 \mathrm{~h}$. The stability of biodiesel is critical to ensure fuel quality at all points along the distribution chain. Among the metals investigated, copper appears to have the strongest detrimental effect. Additional elements such as $\mathrm{Co}, \mathrm{Cu}, \mathrm{Fe}, \mathrm{Mn}$, and $\mathrm{Ni}$ can promote oxidative degradation, whereas some elements such as $\mathrm{Pb}$, and $\mathrm{Zn}$ can also catalyze the biodiesel oxidation. ${ }^{103,104}$

\subsection{Analysis by ICP techniques}

Because the metal concentration in biodiesel is usually low; the selection of the determination technique should be strongly related to the target metal and to its concentration. ${ }^{105}$ The main techniques employed are flame atomic absorption spectrometry (FAAS), graphite furnace atomic absorption spectrometry (ETAAS), inductively coupled plasma atomic emission spectroscopy (ICP-OES) and inductively coupled plasma mass spectrometry (ICP-MS). ${ }^{4,50,90-}$ $93,104-111$ 
The European Standard EN $14214^{101}$ describes the requirements and test methods for FAME analysis, the most common type of biodiesel, whereas, the ASTM D6751-08 ${ }^{102}$ details specifications for biodiesels blended with middle distillate fuels. Both standards establish the

determination of Ca, Mg, K, Na, S and P. The European Standard EN $14538^{112}$ is focused on the determination of $\mathrm{Ca}, \mathrm{Mg}, \mathrm{K}$ and $\mathrm{Na}$, and $\mathrm{EN} 14107^{113}$ on the determination of $\mathrm{P}$ by inductively coupled plasma optical emission spectroscopy (ICP-OES). The effect of the presence of biodiesel in the plasma performances as well as modified sample introduction systems to reduce the impact of biodiesel on the plasma characteristics has been described.

\subsubsection{Conventional sample introduction systems and electrothermal vaporization}

\section{Conventional sample introduction systems}

The first work devoted to the use of ICP-OES for the determination of metals in biodiesel was conducted by Edlund et ll. $^{4}$ The work was focused on the development of a method for the determination of six analytes: $\mathrm{Ca}, \mathrm{K}, \mathrm{Mg}, \mathrm{Na}, \mathrm{Cl}$ and $\mathrm{P}$. The novelty of this work was the use of an argon-oxygen mixed-gas to reduce the background emission of the spectral lines of carbon and carbon compounds when oxygen was added. In fact, for $\mathrm{Na}$ and $\mathrm{K}$, an increase of the signal to background ratios was observed thus lowering the limits of detection. LODs obtained with the argon-oxygen mixed gas were $7.1,1.6$ and $1.4 \mathrm{mg} \mathrm{kg}^{-1}$ for $\mathrm{K} 766.490, \mathrm{Na}$ 588.995 and $\mathrm{Na} 589.592 \mathrm{~nm}$, respectively; whereas operating in the conventional mode, the respective LODs were 220, 59 and $74 \mathrm{mg} \mathrm{kg}^{-1}$. However, it was found that the LODs for Ca, $\mathrm{Mg}, \mathrm{P}$ and $\mathrm{Cl}$ were not improved upon the addition of oxygen to the plasma. The determination of organic chlorine at low $\mathrm{mg} \mathrm{kg}^{-1}$ levels was possible using the intense spectral lines at 134.724 or $135.166 \mathrm{~nm}$. 
The selection of the solvent could influence the quality of the analytical results. Xylene and kerosene were widely used to perform routine analysis of this kind of samples. ${ }^{112-}$ 119 The effect of the solvent selection on the analytical results in the determination of phosphorus by ICP-OES was evaluated by Sánchez et al. ${ }^{120}$ Two sample introduction systems were employed: (i) a concentric micronebulizer fitted to a glass cyclonic spray chamber; and, (ii) the same nebulizer coupled to a glass single pass spray chamber (Torch Integrated Sample Introduction System, TISIS). For a given phosphorous concentration, for the conventional cyclonic spray chamber, the signal enhancement factor observed for xylene with respect to kerosene ranged from 2.9 to 3.9. Similar trends were found for the single pass spray chamber although the influence of the solvent was less marked than that observed for the Cyclonic spray chamber.

Ethanol was proposed as an alternative solvent by dos Santos et al. ${ }^{3}$ for simultaneous determination of $\mathrm{Ca}, \mathrm{P}, \mathrm{Mg}, \mathrm{K}$ and $\mathrm{Na}$ in biodiesel by ICP-OES. Dilution with ethanol enabled the use of aqueous standards, leading to accurate and precise results. An oxygen flow was used to decrease the background and non-spectral interferences were compensated for by employing yttrium as internal standard. The concentration limit established by the standard was higher than the limits of detection obtained with this procedure. The obtained LODs, considering $2.5 \mathrm{~g}$ of sample in a final volume of $25 \mathrm{~mL}$, were: $0.03,0.5,0.005,0.3$ and $0.1 \mu \mathrm{g}$ $\mathrm{g}^{-1}$, for $\mathrm{Ca}, \mathrm{P}, \mathrm{Mg}, \mathrm{K}$ and $\mathrm{Na}$, respectively. Moreover, the validity of the method was evaluated throughout the analysis of four biodiesel samples produced from different raw materials. The samples were spiked with $5 \mu \mathrm{g} \mathrm{g}^{-1}$ of the analytes. Calibration was carried out with standard solutions in ethanol, allowing the use of stock aqueous standard solutions. All recoveries were in the 82 to $114 \%$ range for all analytes, demonstrating the accuracy of the proposed procedure. Moreover, Chaves et al. ${ }^{5}$ evaluated alternative solvents, as ethanol and 1propanol, for the determination of $\mathrm{Ca}, \mathrm{Cu}, \mathrm{Fe}, \mathrm{K}, \mathrm{Mg}, \mathrm{Na}, \mathrm{P}, \mathrm{S}$ and $\mathrm{Zn}$ in biodiesel and 
vegetable oils by ICP-OES. Calibration was carried out against inorganic standards diluted in ethanol or 1-propanol, while yttrium was used as an internal standard, correcting for nonspectral interference and sensitivity drift. Recovery tests yielded figures included within the 87 to $116 \%$ range. The measured precision expressed as relative standard deviation $(n=3)$ was lower than $5 \%$ and limits of detection were at the low $\mu \mathrm{g} \mathrm{g}^{-1}$ level.

While dilution of samples is one of the most widespread approaches, other alternatives have been explored, such as the preparation of the emulsions, to reduce the mass of organic solvent that reaches the plasma. ${ }^{121}$ The emulsification involves the addition of an aqueous phase containing an acid and/or surfactant in an appropriate proportion. ${ }^{122}$ De Souza et al. ${ }^{123}$ developed a simple and rapid method for the simultaneous determination of seven trace elements in biodiesel by axial and radial viewed ICP OES. The sample was emulsified with Triton X-100 and water, yttrium being employed as internal standard. One of the advantages of the emulsification was that aqueous standards could be used. Good recoveries, in the range of 90 to $109 \%$, were achieved for all the studied analytes. Moreover, the LODs obtained in the axial mode went from 0.007 to $0.660 \mu \mathrm{g} \mathrm{g}^{-1}$. Young et al. ${ }^{124}$ developed a method for the determination of sulphur in biodiesel samples based on the sample micro-emulsification. Microemulsions were prepared using $0.5 \mathrm{~mL}$ of $20 \% \mathrm{v} / \mathrm{v} \mathrm{HNO}_{3}, 0.5 \mathrm{~mL}$ of Triton $\mathrm{X}-100,2-3$ $\mathrm{mL}$ of biodiesel sample, and diluted with n-propanol to a final volume of $10 \mathrm{~mL}$. The novelty of the method was the summation of the emission intensities of multiple sulphur lines to increase accuracy and sensitivity. The recoveries obtained ranged from 72 to $119 \%$. Recently, the same emulsifier was used by Lisboa et al. ${ }^{125}$ and, as in the previous work, external calibration with inorganic aqueous standard solutions in the emulsion were used. LOD were in the sub-mg kg-1 range and recoveries went from 91 to $107 \%$.

Moreover, the sample digestion was explored as alternative sample preparation method by Korn et al. ${ }^{126}$ Two digestion procedures were evaluated for the determination of 
$\mathrm{Ca}, \mathrm{P}, \mathrm{Mg}, \mathrm{K}$ and $\mathrm{Na}$ in biodiesel by ICP OES: $(i)$ an open system with conventional heating using concentrated nitric and sulfuric acids and the addition of hydrogen peroxide to complete the digestion; and, (ii) a microwave-assisted closed system using concentrated nitric acid and hydrogen peroxide. The analytical performances were evaluated through the residual carbon contents. These contents were $0.358 \pm 0.012 \%$ with the open system with conventional heating and $0.614 \pm 0.023 \%$ with the microwave-assisted closed vessel system, demonstrating the high efficiency of both proposed procedures. The closed system was preferred because the process was faster and safer. Moreover, the accuracy determined by a recovery test was better than for the open systems. In both cases the LOD were in the sub- $\mu \mathrm{g} \mathrm{g}^{-1}$ range. Inductively Coupled Plasma Mass Spectrometry (ICP-MS) can be an alternative approach for the determination of trace elements in biodiesel. Woods and Fryer ${ }^{50}$ explored the use of an ICPMS instrument fitted with an octopole reaction system (ORS) for the determination of the inorganic elements of several biofuel materials. As a sample preparation procedure the dilution with kerosene was used. The ORS removed matrix- and plasma-based spectral interferences reducing the LOD. In fact the LOD found were $0.0109 \mu \mathrm{g} \mathrm{kg}^{-1}$ and $0.0293 \mathrm{mg}$ $\mathrm{kg}^{-1}$ for Be and $\mathrm{S}$, respectively. Moreover, rapeseed FAME sample was spiked with a multielemental solution and recoveries for all elements went from 90 to $120 \%$, although the majority fell within $5 \%$ of the target value, indicating reliable interference removal for the spiked matrices and the applicability of the technique to trace and ultratrace determination of metallic impurities.

As in ICP-OES, microemulsions have been explored as an alternative sample preparation method. Amais et al. ${ }^{111}$ developed a method for the determination of $\mathrm{Cd}, \mathrm{Co}, \mathrm{Cu}$, $\mathrm{Mn}, \mathrm{Ni}, \mathrm{Pb}, \mathrm{Ti}$, and $\mathrm{Zn}$ in biodiesel microemulsified samples by ICP-MS. Microemulsions were prepared using $0.25 \mathrm{~mL}$ Triton $\mathrm{X}-100,0.25 \mathrm{~mL} 20 \% \mathrm{v} \mathrm{v}-1 \mathrm{HNO}_{3}, 0.50 \mathrm{~mL}$ biodiesel sample and $4.0 \mathrm{~mL}$ n-propanol. The accuracy of the method was evaluated by recovery 
experiments. Recoveries found were in the range 76.5 to $116.2 \%$ for all analytes and LODs were in the $9.6310^{-3}$ to $19.5 \mu \mathrm{g} \mathrm{L}^{-1}$ range. It is important to note, that an oxygen gas flow was additionally incorporated, and as consequence, the background signal increased. In fact, LODs without the additional oxygen gas flow were lower.

\section{Total sample consumption introduction systems}

The sample introduction systems employed in the studies mentioned so far consisted of a nebulizer adapted to a spray chamber. Therefore, a big fraction of the solution initially nebulized did not reach the plasma. Total sample consumption systems have been considered as suitable devices for the analysis or organic samples through ICP techniques. The main advantages of these devices are: (i) low sample volume required to perform the analysis; (ii) high analyte transport efficiency; (iii) low plasma solvent load; (iv) reduction in the volume of waste generated; and, (v) reasonable memory effects. ${ }^{127}$ De Souza et al. $^{128}$ compared the performance of a parallel flow with that of a concentric micronebulizer in terms of their suitability for the elemental determination in biodiesel and other oils by ICP-OES. The main advantage of the parallel path micronebulizers over the conventional ones is the low risk of blockage, thus allowing the introduction of samples with high contents of dissolved solids. Moreover, limits of detection for the parallel flow nebulizer were lower than for the concentric one.

Additional systems have been used to carry out biodiesel analysis. Thus, cross-flow micronebulizers have been modified with an additional channel for the introduction of an

extra liquid flow. ${ }^{129,130}$ In this way, the organic sample is continuously introduced through one channel of the nebulizer, while aqueous calibration standards are sequentially nebulized through the other one. Aerosol droplets generated by both channels are mixed in the spray chamber and the resulting mixture reaches the ICP, thus allowing the analysis of organic 
samples by on-line standard addition calibration using aqueous calibration solutions. Concentric nebulizers were also used for this purpose. ${ }^{131}$ The accuracy of the system was tested by recovery test, for all the analytes, the results were included in the range of 96-101\%.

On the other hand, the spray chamber has been modified to promote the complete transport of the sample to the plasma. In this sense, Sánchez et al. ${ }^{132}$ employed a $350^{\circ} \mathrm{C}$ heated low inner volume single pass spray chamber to mitigate the matrix effects in the analysis of biofuel samples by ICP-OES. The results have proved that the higher the chamber walls temperature, the higher the sensitivity. As a result, limits of detection decreased below $7 \mu \mathrm{g}$ $\mathrm{L}^{-1}$ for elements such as manganese, vanadium and silicon. Furthermore, memory effects were less severe as the temperature raised. Another benefit of increasing the TISIS chamber walls temperature was that matrix effects became less pronounced as compared to a Cyclonic chamber. Thus, at $350^{\circ} \mathrm{C}$ non-spectral interferences were eliminated likely because the analyte transport efficiency to the plasma was close to $100 \%$ irrespective of the sample analyzed. The developed procedure was applied to the analysis of biodiesel with recoveries close to $100 \%$ for four biodiesel samples. The TISIS spray chamber and flow injection was used for the determination of nickel, vanadium and manganese in fuel and biofuel samples by ICP-MS. ${ }^{133}$ In this case, the amount of sample injected was only $2.5 \mu \mathrm{L}$. Moreover, the chamber temperature was optimized in terms of sensitivity and mitigation of matrix effects. It was found that sensitivity peaked at $110^{\circ} \mathrm{C}$ heating temperature. However, non-spectral interferences caused by differences in the matrix composition became less severe as this variable was increased and they were virtually eliminated at $200{ }^{\circ} \mathrm{C}$. As a consequence, a single xylene based standard could be used as a universal standard. ${ }^{134,135}$

\section{Desolvation systems}


Another approach explored for the minimization of the main problems related with the analysis of biodiesel has been to decrease the temperature of the spray chamber, thus reducing the amount of organic sample reaching the plasma. Chaves et al. ${ }^{5}$ demonstrated that cooling a cyclonic spray chamber at $-5^{\circ} \mathrm{C}$ reduced sufficiently the amount of organic solvent introduced into the plasma. Therefore, it was not necessary to introduce oxygen using ethanol and 1propanol as a solvents. For this device, the relative standard deviation was lower than $5 \%$ and limits of detection were at the low $\mu \mathrm{g} \mathrm{g}^{-1}$ level (Table 3).

Electrothermal vaportization (ETV) can be used as an alternative approach to minimize the problems related to the use of conventional sample introduction systems. ${ }^{136,137}$ The main advantage of this device is the separation of the analyte from the matrix sample. This could be explained because the matrix pyrolysis can be produced prior to the analyte vaporization hence mitigating the carbon deposits formation and some polyatomic interferences. ${ }^{138}$ Moreover, due to the low amount of sample introduced (c.a., $20 \mu \mathrm{L}$ ) the problems related to the plasma ionization or excitation capability are avoided. Besides, this sample introduction system allows performing a preconcentration procedure from several consecutive sample injections on the surface of the vaporizer and therefore higher analyte signals are measured. Chaves et al..$^{93}$ developed a methodology for the determination of Co, $\mathrm{Cu}, \mathrm{Fe}, \mathrm{Mn}, \mathrm{Ni}$ and $\mathrm{V}$ in emulsions of diesel and biodiesel samples by ETV-ICP-MS. Pd played two main roles; as a chemical modifier it stabilized the analytes and as a carrier this element improved the transport of the analytes from the ETV to the plasma. The LODs were, in $\mathrm{ng} \mathrm{g}^{-1}, 0.5$ for $\mathrm{Co}, 1.5$ for $\mathrm{Cu} 3$ for $\mathrm{Fe}, 0.3$ for $\mathrm{Mn}, 0.5 \mathrm{Ni}$, and 1 for $\mathrm{V}$. Moreover, recovery tests were carried out to evaluate the accuracy of the method. This parameter was in the 80$120 \%$ range, which covered the expected RSD that for an emulsification sample preparation. Recently, the conventional graphite oven of the ETV has been changed by a tungsten filament. ${ }^{139}$ Advantages of this approach over conventional graphite ovens are: $(i)$ it is simpler 
and less expensive, since it requires a single low power source; and, (ii) minimization of carbides formation, what is highly interesting for the determination of some elements such as silicon. In fact, this element, together with phosphorous were accurately determined following a method based on the use of the heating tungsten coil. Limits of detection of 0.4 and $0.1 \mathrm{mg}$ $\mathrm{kg}^{-1}$ were obtained for $\mathrm{P}$ and $\mathrm{Si}$, respectively. The main drawback of this approach is the transient nature of the signal, which reduces the amounts of elements determined simultaneously. ${ }^{140}$

\subsubsection{Isotopic Dilution Mass Spectrometry (IDMS)}

One of the most challenging issues of the application of isotopic dilution is the mixture between sample and spike isotopes. The ideal scenario is a complete isotopic equilibrium between both, sample and spike isotopes. If the analyte and the isotopically-enriched spike are in the same species a complete mixing is sufficient to guarantee that both are being ionized with the same efficiency. This situation becomes more complicated in biofuels samples which have a very demanding matrix.

To overcome problems related with isotopic equilibration, a pre-treatment step as the digestion of the sample is be required. Recently, Amais et al. ${ }^{141}$ developed a method for the determination of trace sulphur in biodiesel by sector field inductively coupled plasma mass spectrometry (SF-ICP-MS) after sample digestion. The applied procedure involved predigestion and spiking of approximately $0.25 \mathrm{~g}$ aliquots of the samples with ${ }^{34} \mathrm{~S}$ (approximately $0.25 \mathrm{~g}$ of a nominal $10 \mu \mathrm{g} \mathrm{g}^{-1}{ }^{34} \mathrm{~S}$ solution). For the digestion of the sample, a diluted nitric acid and hydrogen peroxide decomposition medium was used. Furthermore, medium

resolution mode was employed to eliminate isobaric interferences at ${ }^{32} \mathrm{~S}$ and ${ }^{34} \mathrm{~S}$ caused by polyatomic phosphorus and oxygen species, as well as sulfur hydride ions. The accuracy and 
the precision of the method were tested by analysing a diesel certified reference material. Despite the favourable accuracy and precision of the proposed method, it did not have a limit of detection low enough to conduct $S$ determination whith an approximate $S$ mass fraction lower than $0.6 \mathrm{mg} \mathrm{kg}^{-1}$. This was due to the magnitude of the instrument background.

One of the main drawbacks of the SF-ICP-MS is 10 -fold reduction in ion transmission efficiency and hence, in signal intensity. Moreover, the cost of this type of instruments is higher than for a quadrupole-based ICP-MS. This is why Balcaen et.al. ${ }^{142}$ used a triple quadrupole (ICP-QQQ) instrument for the determination of S by isotope dilution. This system consisted in an octopole-based collision/reaction cell located between two quadrupole analyzers. The major advantage of the ICP-QQQ is the enhanced control over the chemical resolution of spectral overlap owing to the double mass selection in MS/MS mode, allowing the determination of $\mathrm{S}$ after the conversion of $\mathrm{S}^{+}$ions into $\mathrm{SO}^{+}$ions by means of oxygen as a reaction gas. However, in biodiesel matrix, containing $\mathrm{Ca}$, $\mathrm{Ti}$ or $\mathrm{Cr}$, it is expected that this approach does not provide accurate results for isotope dilution. This problem was solved by using ICP-MS/MS. As a proof-of-concept, the technique was successfully applied to the S determination in a biodiesel reference material. Moreover, LOD for this approach were in the range of $\mu \mathrm{g} \mathrm{kg}^{-1}$.

\subsection{Analysis by additional techniques}

Alternative techniques have been proposed for the determination of trace elements in biodiesel samples. In this way, FAES, ${ }^{101,106,143,144}$ FAAS, ${ }^{90,109,145-149}$ and ETAAS $^{91,93,105,107,108,110,113,150-158}$ have been used to quantify some alkaline metals in these samples. Other alternative techniques have been MIP-OES, ${ }^{159}$ ionic chromatography, ${ }^{160,161}$ capillary electrophoresis ${ }^{162,163}$ and voltammetry. ${ }^{164-169}$ 
Flame Atomic Emission Spectrometry (FAES) could be considered as a low cost alternative for the determination of the four major elements $(\mathrm{Ca}, \mathrm{Na}, \mathrm{K}$ and $\mathrm{Mg}$ ) in biodiesel samples. Alkalines are easily and efficiently atomized in flames. ${ }^{143}$ A method for the determination of $\mathrm{Na}$ and $\mathrm{K}$ in biodiesel, from different vegetable oils, was proposed by Chaves et al. ${ }^{144}$. Microemulsions were prepared by mixing biodiesel samples with n-propanol and aqueous acid solution, which allowed the use of inorganic aqueous standards for the calibration. Sample introduction through discrete aspiration or by continuous aspiration (CA) were compared, moreover, the results obtained with ICP-OES were taken as a reference. Na and $\mathrm{K}$ concentrations were determined and for the employed methods, the values obtained were not significantly different for a 95\% confidence level. Furthermore, by comparing LOD for discrete and continuous aspiration modes, values lower than $0.1 \mu \mathrm{g} \mathrm{g}^{-1}$ were obtained. The direct dissolution of the sample into ethanol was proposed by Barros et al. ${ }^{106}$. The main advantage of the use of ethanol as a sovent is that aqueous standards can be employed for calibration. Two different sample:solvent proportions were evaluated, 1:10 and 1:20. The limits of quantification (LOQ) in biodiesel/ethanol solution (1:20, w/v) were 4.00 and 3.60 $\mathrm{mg} \mathrm{kg}^{-1}$ for $\mathrm{Na}$ and $\mathrm{K}$, respectively. In 1:10 (w/v) biodiesel/ethanol solutions the LOQ were 2.16 and $2.00 \mathrm{mg} \mathrm{kg}^{-1}$ for $\mathrm{Na}$ and $\mathrm{K}$, respectively. In both cases LOQs were lower than the limit established in the EN $14214\left(5 \mathrm{mg} \mathrm{kg}^{-1}\right) .{ }^{101}$ Moreover, the feasibility of the use of aqueous standards was studied by recoveries test. For both metals, the recoveries were in the range $91-108 \%$, which indicates that the accuracy of the method is sufficient to meet the legislative requirements for quality control of biodiesel.

Flame Atomic Absorption Spectrometry (FAAS) has been explored as an alternative to ICP techniques for the determination of $\mathrm{K}, \mathrm{Na}, \mathrm{Ca}$ and $\mathrm{Mg}$ in biodiesel samples. The advantage of this technique is that it is simpler, cheaper and more tolerant to organic matrices than ICP. The dilution of biodiesel sample in xylene or n-hexane is widely used as 
pretreatment sample step. In fact, it has been recommend by international legislation. ${ }^{145-147}$ However, the main drawback of this technique is that organometallic standards are required, which have a low stability in solution and are expensive. Ethanol ${ }^{148}$ was compared with xylene as solvent for the determination of $\mathrm{Ca}, \mathrm{K}, \mathrm{Na}$ and $\mathrm{Mg}$ in biodiesel. It was observed that the ethanolic medium provided greater sensitivity for $\mathrm{K}$ and $\mathrm{Mg}$; whereas, for $\mathrm{Ca}$ and $\mathrm{Na}$, similar sensitivities were obtained using both media. Because the surface tension of ethanol is lower than for xylene, the nebulization process is favored, thus increasing the mass of analyte reaching the flame. Moreover, since a higher proportion of ethanol reached the flame, compared to xylene, the flame temperature increased. In the case of $\mathrm{Ca}$, a different flame was used $\left(\mathrm{N}_{2} \mathrm{O} / \mathrm{C}_{2} \mathrm{H}_{2}\right)$, and the temperature increase due to the presence of the organic solvents became less significant.

As in ICP techniques, microemulsification of the sample has been applied allowing the use of aqueous standards. De Jesus et.al. ${ }^{90}$ used n-pentanol, Triton X-100 and water for the microemulsion preparation. Microemulsified aqueous standards were employed. The flame composition was optimized in terms of sensitivity and the optimal $\mathrm{C}_{2} \mathrm{H}_{2}$ /air ratio was 0.131 . For these experimental conditions the limits of detection obtained were $0.1 \mu \mathrm{g} \mathrm{g}^{-1}$ and $0.06 \mu \mathrm{g}$ $\mathrm{g}^{-1}$ for sodium and potassium, respectively. The LODs obtained were compared with those obtained following the European Standards ${ }^{146,147}$ and higher values were found for the dilution procedure $\left(0.2 \mu \mathrm{g} \mathrm{g}^{-1}\right.$ and $0.1 \mu \mathrm{g} \mathrm{g}^{-1}$ for sodium and potassium, respectively). The same emulsifier was used by Amais et al. ${ }^{149}$,whereas a different flame composition was employed. LODs were in the same range as in the previous work. Additional emulsifiers have been applied for the alkaline metals in this kind of samples. Lyra et al. ${ }^{109}$ prepared the microemulsification by using $\mathrm{HNO}_{3}, \mathrm{CsCl}$, for sodium and potassium determination, $\mathrm{KCl}$, for calcium and magnesium determination, and n-propanol. 
Electrothermal atomic absortion spectrometry (ETAAS) sensitivity could be 2-3 orders of magnitude higher than that of FAAS. For this reason it has been used for the analysis of some metals in petroleum samples. ${ }^{105,150}$ The field of application of this determination technique has been extended to biodiesel samples by several research groups. Lobo et al. ${ }^{91}$ developed a method for the $\mathrm{Ni}$ and $\mathrm{Cd}$ analysis using microemulsion as a sample preparation. Tungsten was employed as a chemical modifier. In a previous work, two chemical modifiers $(\mathrm{Pd}+\mathrm{Mg}$ and $\mathrm{W})$ and two distinct sample preparation procedures (microemulsion and wet digestion in a focused microwave system) were investigated ${ }^{108}$ and the optimum experimental conditions corresponded to microemulsion preparation and use of W. Recoveries were measured varying from $93 \%$ to $108 \%$ for $\mathrm{Ni}$ and from $98 \%$ to $116 \%$ for Cd. Therefore, the accuracy was good enough for the routine analysis of these samples. The improvement of the sensitivity attainable by ETAAS and the advantages of the emulsion sample preparation, were taken for the determination of $\mathrm{Cd}$ and $\mathrm{Hg}$ in this kind of samples at $\mu \mathrm{g} \mathrm{kg}^{-1}$ level. ${ }^{151}$ Ghisi et al. ${ }^{107}$ developed a method for the determination of $\mathrm{Cu}$ and $\mathrm{Fe}$. The procedure for the sample preparation was its treatment with tetramethylammonium hydroxide (TMAH) as an alternative to sample dilution and emulsification. The main advantage was that the analyte was not diluted therefore an improvement of the limits of detection was expected. Moreover, this treatment of the sample allowed the use of higher pyrolysis temperature eliminating the majority of the matrix before atomization thus mitigating interferences.

In order to improve LODs, de Jesus et al. ${ }^{152}$ proposed direct sampling graphite furnace atomic absorption spectrometry for the determination of As and $\mathrm{Cd}$. The samples were weighed directly on the solid sampling platforms and introduced into the graphite tube for analysis, thus reducing the contamination problems and increasing the sensitivity. The chemical modifier used was a mixture of $0.1 \% \mathrm{Pd}+0.06 \% \mathrm{Mg}+0.06 \%$ Triton $\mathrm{X}-100$. The suitability of Pd and $\mathrm{Mg}$ as modifier, was previously established for petroleum sample. ${ }^{153-155}$ 
However, the main drawback of this technique was its relatively high uncertainty, which was typically around 5-20\% RSD. This result was explained in terms of the heterogeneity of natural samples and the small amount of sample (8 and $10 \mathrm{mg}$ for As and Cd, respectively) which was introduced into the atomizer. ${ }^{152}$

Phosphorous determination is not commonly carried out by AAS, since its three resonance lines are in the ultraviolet vacuum (UV). Therefore, non-resonance lines $(213.6 \mathrm{~nm}$ and $214.9 \mathrm{~nm}$ ) should be used. As a result, poor limits of detection may be found. In order to reduce LOD, phosphorous was stabilized by adding chemical modifiers thus avoiding the formation of volatile molecular species. ${ }^{156}$ Several modifiers were evaluated: $\mathrm{Pd}, \mathrm{Pd}+\mathrm{Ca}$ and $\mathrm{Pd}+\mathrm{Mg}$. The results showed that Pd was the best option in terms of sensitivity $(213.6 \mathrm{~nm})$. The suitability of the method was evaluated by comparison with the EN $14107 .{ }^{113}$ No significant differences were observed between the results afforded by the proposed and the standard procedures. Another important issue in the $\mathrm{P}$ determination affecting the LOD is that the P hollow cathode lamps are among the least intense ones. This problem could be solved by means of high-resolution continuum source graphite furnace atomic absorption spectrometry (HR-CS AAS). Moreover, HR-CS AAS allowed the simultaneous observation of the $\mathrm{P}$ atomic lines and PO molecular bands. Therefore, the selection of the chemical modifier plays a critical role. Again Pd-based modifiers enhanced the formation of P atoms, whereas inhibited the formation of PO molecules. ${ }^{157}$ The advantages of this technique were demonstrated by the decrease of the LOD $\left(0.5 \mu \mathrm{g} \mathrm{g}^{-1}\right)$ in comparison with the conventional ETAAS. ${ }^{158}$ The unsurpassed background correction systems, the visualization of the entire analytical spectrum and the improvement on the LODs due to the HR-CS AAS were advantageous for the determination of $\mathrm{Al}, \mathrm{Cu}, \mathrm{Fe}$ and $\mathrm{Mn} .{ }^{110}$ For the improvement of the $\mathrm{Al}$ analytical figures of merit, a platform pre-treated with $\mathrm{Zr}$ as a permanent chemical modifier was employed to prevent the formation of aluminium carbide. Furthermore, different 
calibration approaches were used depending on the analyte. For $\mathrm{Cu}, \mathrm{Fe}$ and $\mathrm{Mn}$, the calibration was carried out using aqueous standards, whereas, ethanolic ones were used for Al. LODs for $\mathrm{Cu}, \mathrm{Fe}$ and $\mathrm{Mn}$ obtained with this approach were similar to those found for ETV-ICP-MS. ${ }^{93}$

A procedure for total and inorganic mercury determination in biodiesel by CV-AFS was developed by Aranda et $a .{ }^{95}$ The samples were introduced directly as oil-in-water emulsions in a flow injection manifold. Mercury vapour was generated using an acidic $\mathrm{SnCl}_{2}$ solution in a continuous flow system what gave a $0.2 \mu \mathrm{g} \mathrm{kg}^{-1} \mathrm{LOD}$.

Dancsak et al. ${ }^{170}$ have recently employed tungsten filaments extracted from microscope light bulbs to decompose biodiesel matrix, and atomize and excite the analytes to determine sodium, potassium, chromium and vanadium by tungsten coil atomic emission spectrometry (WCAES). The accuracy was checked by determining $\mathrm{Na}$ and $\mathrm{K}$ in a biodiesel reference sample and carrying out spike experiments for $\mathrm{Cr}$ and $\mathrm{V}$. No statistically significant differences were observed between reference and determined values for all analytes at a 95\% confidence level.

Microwave-induced plasma optical emission spectrometry (MIP-OES) and a flow blurring nebulizer were used to determine silicon in diesel and biodiesel samples by Amais et $a l .{ }^{159}$ A simple dilution with ethanol was used as sample preparation procedure. Two additional sample preparation methods were also evaluated for comparison: closed-vessel microwave-assisted acid digestion and microemulsification. Limits of detection (LOD) vary from 5 to $20 \mu \mathrm{g} \mathrm{L}^{-1}$ and relative standard deviations (RSD) were lower than $2 \%$ in all cases.

Ion chromatography has been employed for the determination of elements such as $\mathrm{Na}$, $\mathrm{Ca}, \mathrm{K}, \mathrm{Mg}^{160}$ and $\mathrm{P} .{ }^{161}$ De Caland et.al. ${ }^{160}$ developed a method for the quantitative determination of $\mathrm{Na}^{+}, \mathrm{K}^{+}, \mathrm{Mg}^{2+}$ and $\mathrm{Ca}^{2+}$. The proposed method employed water extraction, heating and ultrasound as a pre-treatment sample procedure. For comparison, the samples 
were also analyzed using ICP-OES with similar accuracy and precision results. Zhang et al. ${ }^{161}$ developed a method to measure the content of inorganic phosphate in oil samples, by direct injection of solvent extracted oil into ion chromatography. Biodiesel oils were dissolved in acetone and an ion chromatography system with sample matrix elimination function was applied to directly determine their phosphate content against acetone based standards.

Capillary electrophoresis equipped with a diode array detector was used for the determination of $\mathrm{Na}^{+}, \mathrm{K}^{+}, \mathrm{Ca}^{2+}, \mathrm{Mg}^{2}$, using barium $\left(\mathrm{Ba}^{2+}\right)$ as internal standard. ${ }^{162}$ Separation was conducted in a fused-silica capillary column with indirect UV detection at $214 \mathrm{~nm}$. The method presented a good linearity in the concentration range of $0.5-20 \mathrm{mg} \mathrm{kg}^{-1}$. The same separation technique coupled to a conductivity detector was used for the determination of the four main cations among other species (i.e. sulfate, phosphate, formate, acetate, propionate and glycerol). ${ }^{163}$

Moreover, voltammetry has been used for the determination of metal contents in biodiesel samples. A method for $\mathrm{P}$ quantification in the form of phosphate using a 1:12 phosphomolybdic film modified glassy carbon electrode in cyclic voltammetry was developed by Zezza et al. ${ }^{164}$ Anodic stripping voltammetry has been also applied for biodiesel analysis. Pinto et al. ${ }^{166}$ optimized the determination of trace levels of $\mathrm{Cd}^{+2}, \mathrm{Cu}^{+2}, \mathrm{~Pb}^{+2}$ and $\mathrm{Zn}^{+2}$ via ASV using a bismuth film electrode. Deposition time and voltage step were the most important factors identified. The optimized method was applied to the determination of these elements in biodiesel samples after microwave digestion with diluted acid, presenting satisfactory values for accuracy and precision. A mercury film electrode was used by Martiniano et al. ${ }^{165}$ to determine direct and simultaneously $\mathrm{Pb}^{+2}$ and $\mathrm{Cu}^{+2}$. De Souza et al. ${ }^{115}$ used a nickel hexacyanoferrate-modified electrode $\mathrm{K}^{+}$. The modified electrodes exhibited a linear response in the concentration range of $4.0 \times 10^{-5}$ to $1.0 \times 10^{-2} \mathrm{~mol} \mathrm{~L}^{-1}$, with a detection limit of $1.9 \times 10^{-5} \mathrm{~mol} \mathrm{~L}^{-1}$. A chemically modified electrode with nanoparticles of nickel 
hexacyanoferrate was employed for the determination of potassium ions in a microemulsion of biodiesel. ${ }^{114}$ An alternative method for the determination of calcium in biodiesel samples using square-wave voltammetry and a glassy carbon electrode in a solution containing EDTA was proposed by Almeida et al. ${ }^{169}$ A microwave assisted acid digestion of the biodiesel samples was carried out before analysis. In addition, good reproducibility (CV maximum of $0.70 \%$ ) and accuracy (recovery around 102\%) were obtained making the method suitable for the determination of $\mathrm{Ca}^{2+}$ in biodiesel samples.

Table 3. Summary of the limits of detection obtained in biodiesel samples by several authors.

\begin{tabular}{|c|c|c|c|c|c|}
\hline $\begin{array}{l}\text { Elemen } \\
\qquad \mathbf{t}\end{array}$ & Technique & Conditions & LOD & $\begin{array}{c}\text { Range } \\
\text { concentratio } \\
\text { n (min-max) }\end{array}$ & $\begin{array}{c}\text { Referenc } \\
\text { e }\end{array}$ \\
\hline $\mathrm{Ag}$ & ICP-MS & EC (Kerosene,1:3) & $\begin{array}{c}0.149 \mu \mathrm{g} \\
\mathrm{kg}^{-1}\end{array}$ & $\begin{array}{c}0.257-3.15 \\
\mu g \mathrm{~kg}^{-1}\end{array}$ & 50 \\
\hline Al & ETAAS & $\begin{array}{c}\mathrm{EC}(\text { Ethanol, } 1: 5 \mathrm{~m}: \mathrm{v}) \\
\mathrm{Pd}\left(\mathrm{NO}_{3}\right)_{2}+\mathrm{Mg}\left(\mathrm{NO}_{3}\right)_{2} \\
\text { as modifier }\end{array}$ & $0.013 \mu \mathrm{g} \mathrm{g}^{-1}$ & $\begin{array}{c}0.038-0.443 \\
\mu g g^{-1}\end{array}$ & 110 \\
\hline \multirow[t]{2}{*}{ As } & ICP-MS & EC (Kerosene,1:3) & $\begin{array}{c}0.066 \mu g \\
\mathrm{~kg}^{-1}\end{array}$ & $\begin{array}{c}1.02-1.29 \\
\mu g \mathrm{~kg}^{-1}\end{array}$ & 50 \\
\hline & ETAAS & $\begin{array}{l}\text { EC (Direct sampling) } \\
\text { Pd + Mg + Triton X- } \\
100 \text { as modifier }\end{array}$ & $5.1 \mu \mathrm{g} \mathrm{kg}^{-1}$ & n.d. & 152 \\
\hline B & ICP-MS & EC (Kerosene,1:3) & $6.57 \mu \mathrm{kg}^{-1}$ & $40.3-334 \mu g$ & 50 \\
\hline
\end{tabular}




\begin{tabular}{|c|c|c|c|c|c|}
\hline & & & & $\mathrm{kg}^{-1}$ & \\
\hline $\mathrm{Ba}$ & ICP-MS & EC (Kerosene,1:3) & $\begin{array}{c}0.0990 \mu g \\
k g^{-1}\end{array}$ & $\begin{array}{c}4.64-55.8 \\
\mu g \mathrm{~kg}^{-1}\end{array}$ & 50 \\
\hline $\mathrm{Be}$ & ICP-MS & EC (Kerosene,1:3) & $\begin{array}{c}0.0109 \mu \mathrm{g} \\
\mathrm{kg}^{-1}\end{array}$ & $\begin{array}{c}0.0202- \\
0.0609 \mu \mathrm{g} \\
\mathrm{kg}^{-1}\end{array}$ & 50 \\
\hline \multirow[t]{7}{*}{$\mathrm{Ca}$} & ICP-OES & EC (Kerosene, 1:4) & $\begin{array}{c}0.4-9 \mu g \\
k^{-1}\end{array}$ & $\begin{array}{c}2-10 \mathrm{mg} \mathrm{kg}^{-} \\
1\end{array}$ & 4 \\
\hline & ICP-OES & EC (Kerosene, 1:10) & $\begin{array}{c}0.003 \mathrm{mg} \\
\mathrm{kg}^{-1}\end{array}$ & $\begin{array}{c}0.603-401.2 \\
\mathrm{mg} \mathrm{kg}^{-1}\end{array}$ & 114 \\
\hline & ICP-OES & EC (Kerosene, 1:10) & $\begin{array}{c}0.05 \mathrm{mg} \\
\mathrm{kg}^{-1}\end{array}$ & $\begin{array}{c}0.06-7.4 \mathrm{mg} \\
\mathrm{kg}^{-1}\end{array}$ & 116 \\
\hline & ICP-OES & EC (Kerosene, 1:10) & $\begin{array}{c}0.04 \mathrm{mg} \\
\mathrm{kg}^{-1}\end{array}$ & $\begin{array}{c}0.17-36.3 \\
\mathrm{mg} \mathrm{kg}^{-1}\end{array}$ & 118 \\
\hline & ICP-OES & $\begin{array}{c}\text { EC (Ethanol, 1:10) } \\
\text { IS: Y }\end{array}$ & $0.03 \mu \mathrm{g} \mathrm{g}^{-1}$ & $\begin{array}{c}0.38-0.56 \\
\mu g g^{-1}\end{array}$ & 3 \\
\hline & ICP-OES & $\begin{array}{c}\text { EC (Ethanol, 1:10 for } \\
\text { vegetable oil and 1:20 } \\
\text { biodiesel) } \\
\text { IS: Y }\end{array}$ & $0.08 \mu \mathrm{g} \mathrm{g}^{-1}$ & $\begin{array}{c}0.4-28.5 \mu g \\
g^{-1}\end{array}$ & 5 \\
\hline & ICP-OES & $\begin{array}{l}\text { EC (1-Propanol, 1:10 } \\
\text { for vegetable oil and } \\
\text { 1:20 biodiesel) }\end{array}$ & $0.05 \mu g^{-1}$ & $\begin{array}{c}0.4-28.5 \mu g \\
g^{-1}\end{array}$ & 5 \\
\hline
\end{tabular}




\begin{tabular}{|c|c|c|c|c|}
\hline & IS: Y & & & \\
\hline ICP-OES & $\begin{array}{l}\text { EC (Aqueous } \\
\text { standards) } \\
\text { Emulsification }\end{array}$ & $0.05 \mu \mathrm{g} \mathrm{g}^{-1}$ & $\begin{array}{c}0.19-1.09 \\
\mu g^{-1}\end{array}$ & 123 \\
\hline ICP-OES & $\begin{array}{l}\text { EC (Aqueous } \\
\text { standards) } \\
\text { Emulsification } \\
\text { IS: Y }\end{array}$ & $\begin{array}{c}0.121 \mathrm{mg} \\
\mathrm{kg}^{-1}\end{array}$ & $\begin{array}{c}0.27-0.32 \\
\mathrm{mg} \mathrm{kg}^{-1}\end{array}$ & 125 \\
\hline ICP-OES & $\begin{array}{c}\text { EC (Open digestion) } \\
\text { IS: Y }\end{array}$ & $0.78 \mu g^{-1}$ & n.d. & 126 \\
\hline ICP-OES & $\begin{array}{c}\text { EC (Microwave close } \\
\text { digestion) } \\
\text { IS: Y }\end{array}$ & $0.40 \mu g^{-1}$ & n.d. & 126 \\
\hline ICP-MS & EC (Kerosene,1:3) & $6.40 \mu \mathrm{g} \mathrm{kg}^{-1}$ & $\begin{array}{c}20.8-135 \mu g \\
\mathrm{~kg}^{-1}\end{array}$ & 50 \\
\hline FAAS & $\begin{array}{c}\text { EC (Ethanol, 1:10 } \\
\text { m:v)) }\end{array}$ & $\begin{array}{c}0.31 \mathrm{mg} \\
\mathrm{kg}^{-1}\end{array}$ & $\begin{array}{c}0.37-1.30 \\
\mathrm{mg} \mathrm{kg}^{-1}\end{array}$ & 148 \\
\hline FAAS & $\begin{array}{c}\text { EC } \\
\text { Microemulsification }\end{array}$ & $0.11 \mathrm{mg} \mathrm{L}^{-1}$ & n.d. & 149 \\
\hline FAAS & $\begin{array}{c}\text { EC } \\
\text { Microemulsification }\end{array}$ & $0.1 \mu \mathrm{g} \mathrm{g}^{-1}$ & $\begin{array}{c}0.10-5.34 \\
\mu g g^{-1}\end{array}$ & 109 \\
\hline IC & $\mathrm{EC}\left(\mathrm{Ca}^{2+}\right)$ & $0.23 \mathrm{mg} \mathrm{kg}^{-1}$ & $\begin{array}{c}0.42-6.64 \\
m g ~ k g\end{array}$ & 160 \\
\hline
\end{tabular}




\begin{tabular}{|c|c|c|c|c|c|}
\hline & $\begin{array}{l}\text { CE + Diode } \\
\text { array detector }\end{array}$ & $\begin{array}{c}\text { IS } \\
\text { Liquid-liquid } \\
\text { extraction } \\
\left(\mathrm{Ca}^{2+}\right)\end{array}$ & $0.3 \mathrm{mg} \mathrm{kg}^{-1}$ & $\begin{array}{c}1.9-3.4 \mathrm{mg} \\
\mathrm{kg}^{-1}\end{array}$ & 162 \\
\hline & $\begin{array}{l}\text { CE + Coupled } \\
\text { contactless } \\
\text { conductivity } \\
\text { detector }\end{array}$ & $\begin{array}{l}\text { Liquid-liquid } \\
\text { extraction } \\
\qquad\left(\mathrm{Ca}^{2+}\right)\end{array}$ & $0.12 \mathrm{mg} \mathrm{L}^{-1}$ & $\begin{array}{c}0.12-0.23 \\
\mathrm{mg} \mathrm{kg}^{-1}\end{array}$ & 163 \\
\hline & $\begin{array}{l}\text { Squarewave } \\
\text { Voltammetry }\end{array}$ & $\begin{array}{c}\text { Glassy carbon } \\
\text { electrode } \\
\text { Sample digestion } \\
\text { Standard addition } \\
\qquad\left(\mathrm{Ca}^{2+}\right)\end{array}$ & $\begin{array}{l}1.610-3 \\
\mu \mathrm{mol} \mathrm{L}^{-1}\end{array}$ & $\begin{array}{c}0.34-2.84 \\
\mu \mathrm{mol} \mathrm{L}\end{array}$ & 169 \\
\hline & HR-CS FAAS & EC (Xylene, 1:10 m:v) & $0.34 \mathrm{mg} \mathrm{kg}^{-1}$ & $\begin{array}{c}2.09-2.11 \\
\mathrm{mg} \mathrm{kg}^{-1}\end{array}$ & 145 \\
\hline & LS FAAS & EC (Xylene, 1:10 m:v) & $0.52 \mathrm{mg} \mathrm{kg}^{-1}$ & $\begin{array}{c}2.09-2.11 \\
\mathrm{mg} \mathrm{kg}^{-1}\end{array}$ & 145 \\
\hline $\mathrm{Cd}$ & ICP-MS & EC (Kerosene,1:3) & $\begin{array}{c}0.108 \mu \mathrm{g} \\
\mathrm{kg}^{-1}\end{array}$ & $\begin{array}{c}0.304-0.589 \\
\mu g k^{-1}\end{array}$ & 50 \\
\hline & ICP-MS & $\begin{array}{c}\text { EC (Aqueous } \\
\text { standards) } \\
\text { Microemulsification }\end{array}$ & $\begin{array}{c}9.6310^{-3}- \\
7.7710^{-2} \mu g \\
L^{-1}\end{array}$ & $\begin{array}{c}0.14-0.25 \\
\mu g L^{-1}\end{array}$ & 111 \\
\hline & ETAAS & EC & $0.1 \mu \mathrm{g} \mathrm{L}^{-1}$ & n.d. & 91 \\
\hline
\end{tabular}




\begin{tabular}{|c|c|c|c|c|c|}
\hline & & $\begin{array}{l}\text { Microemulsification } \\
\text { W as modifier }\end{array}$ & & & \\
\hline & ETAAS & $\begin{array}{l}\text { Standard addition } \\
\text { Emulsification } \\
\text { Pd-Mg mixture as } \\
\text { modifier }\end{array}$ & $0.3 \mu \mathrm{g} \mathrm{kg}^{-1}$ & $4.83 \mu \mathrm{g} \mathrm{kg}^{-1}$ & 151 \\
\hline & ETAAS & $\begin{array}{l}\text { EC (Direct sampling) } \\
0.1 \% \mathrm{Pd}+0.06 \% \mathrm{Mg}+ \\
0.06 \% \text { Triton } \mathrm{X}-100 \text { as } \\
\text { modifier }\end{array}$ & $0.2 \mu \mathrm{gg}^{-1}$ & n.d. & 152 \\
\hline & $\begin{array}{l}\text { Anodic } \\
\text { stripping } \\
\text { voltammetry }\end{array}$ & $\begin{array}{c}\text { Bismuth film } \\
\text { electrode } \\
\text { Sample digestion } \\
\left(\mathrm{Cd}^{2+}\right)\end{array}$ & $2 \mathrm{ng} \mathrm{L}^{-1}$ & $\begin{array}{c}0.17-0.65 \\
m g ~ k g\end{array}$ & 166 \\
\hline $\mathrm{Cl}$ & ICP-OES & EC (Kerosene, 1:4) & $\begin{array}{c}400-950 \mu g \\
k^{-1}\end{array}$ & n.d. & 4 \\
\hline Co & ICP-MS & EC (Kerosene,1:3) & $\begin{array}{c}0.0337 \mu g \\
\mathrm{~kg}^{-1}\end{array}$ & $\begin{array}{c}0.0449- \\
0.124 \mu g k g^{-1}\end{array}$ & 50 \\
\hline & ICP-MS & $\begin{array}{c}\text { EC (Aqueous } \\
\text { standards) } \\
\text { Microemulsification }\end{array}$ & $\begin{array}{c}9.2310^{-2} \mu g \\
L^{-1}\end{array}$ & $\begin{array}{c}5.87-6.11 \\
\mu \mathrm{g} \mathrm{L}^{-1}\end{array}$ & 111 \\
\hline & $\begin{array}{l}\text { ETV-ICP-MS } \\
\text { (Pd as }\end{array}$ & EC & $0.5 \mathrm{ng} \mathrm{g}^{-1}$ & n.d. & 93 \\
\hline
\end{tabular}




\begin{tabular}{|c|c|c|c|c|c|}
\hline & modifier) & & & & \\
\hline \multirow[t]{3}{*}{$\mathrm{Cr}$} & ICP-OES & EC (Kerosene, 1:10) & $\begin{array}{c}0.011 \mathrm{mg} \\
\mathrm{kg}^{-1}\end{array}$ & $0.269 \mathrm{mg} \mathrm{kg}^{-1}$ & 114 \\
\hline & ICP-MS & EC (Kerosene,1:3) & $\begin{array}{c}0.0224 \mu \mathrm{g} \\
\mathrm{kg}^{-1}\end{array}$ & $\begin{array}{c}0.376-1.36 \\
\mu g \mathrm{~kg}^{-1}\end{array}$ & 50 \\
\hline & WCAES & $\begin{array}{l}\text { Tungsten coil } \\
\text { atomizer } \\
\text { Standard addition }\end{array}$ & $\begin{array}{c}70-300 \mu g \\
\mathrm{~kg}^{-1}\end{array}$ & n.d. & 170 \\
\hline \multirow[t]{5}{*}{$\mathrm{Cu}$} & ICP-OES & EC (Kerosene, 1:10) & $\begin{array}{c}0.003 \mathrm{mg} \\
\mathrm{kg}^{-1}\end{array}$ & $\begin{array}{c}0.118-0.869 \\
\mathrm{mg} \mathrm{kg}^{-1}\end{array}$ & 114 \\
\hline & ICP-OES & $\begin{array}{c}\text { EC (Ethanol, 1:10 for } \\
\text { vegetable oil and 1:20 } \\
\text { biodiesel) } \\
\text { IS: Y }\end{array}$ & $0.01 \mu \mathrm{g} \mathrm{g}^{-1}$ & $\begin{array}{c}0.14-1.62 \\
\mu g^{-1}\end{array}$ & 5 \\
\hline & ICP-OES & $\begin{array}{l}\text { EC (1-Propanol, 1:10 } \\
\text { for vegetable oil and } \\
\text { 1:20 biodiesel) } \\
\text { IS: } Y\end{array}$ & $0.008 \mu \mathrm{g} \mathrm{g}^{-1}$ & $\begin{array}{c}0.14-1.62 \\
\mu g^{-1}\end{array}$ & 5 \\
\hline & ICP-OES & $\begin{array}{l}\text { EC (Aqueous } \\
\text { standards) } \\
\text { Emulsification }\end{array}$ & $0.03 \mu \mathrm{g} \mathrm{g}^{-1}$ & $\begin{array}{c}0.99-1.09 \\
\mu g g^{-1}\end{array}$ & 123 \\
\hline & ICP-OES & $\begin{array}{l}\text { EC (Aqueous } \\
\text { standards) }\end{array}$ & $\begin{array}{c}0.008 \mathrm{mg} \\
\mathrm{kg}^{-1}\end{array}$ & $\begin{array}{c}<0.008- \\
0.303 \mathrm{mg} \mathrm{kg}^{-1}\end{array}$ & 125 \\
\hline
\end{tabular}




\begin{tabular}{|c|c|c|c|c|}
\hline & $\begin{array}{c}\text { Emulsification } \\
\text { IS: } Y\end{array}$ & & & \\
\hline ICP-MS & EC (Kerosene,1:3) & $\begin{array}{c}0.0264 \mu \mathrm{g} \\
\mathrm{kg}^{-1}\end{array}$ & $\begin{array}{c}0.730-11.5 \\
\mu g \mathrm{~kg}^{-1}\end{array}$ & 50 \\
\hline ICP-MS & EC (Kerosene,1:3) & $\begin{array}{c}0.101 \mu \mathrm{g} \\
\mathrm{kg}^{-1}\end{array}$ & $\begin{array}{c}0.730-11.5 \\
\mu g \mathrm{~kg}^{-1}\end{array}$ & 50 \\
\hline ICP-MS & $\begin{array}{c}\text { EC (Aqueous } \\
\text { standards) } \\
\text { Microemulsification }\end{array}$ & $\begin{array}{c}5.13-5.47 \\
\mu g \mathrm{~L}^{-1}\end{array}$ & n.d. & 111 \\
\hline $\begin{array}{l}\text { ETV-ICP-MS } \\
\qquad \text { (Pd as } \\
\text { modifier) }\end{array}$ & EC & $1.5 \mathrm{ng} \mathrm{g}^{-1}$ & $\begin{array}{c}13.8-142 \mathrm{ng} \\
\mathrm{g}^{-1}\end{array}$ & 93 \\
\hline ETAAS & $\begin{array}{l}\text { EC (Treatment with } \\
\text { tetramethylammoniu } \\
\text { m hydroxide) } \\
0.1 \% \mathrm{Pd}+0.06 \% \mathrm{Mg}+ \\
0.06 \% \text { Triton } \mathrm{X}^{-1} 00 \text { as } \\
\text { modifier }\end{array}$ & $15 \mathrm{ng} \mathrm{g}^{-1}$ & $\begin{array}{c}130-182 \mathrm{ng} \\
\mathrm{g}^{-1}\end{array}$ & 107 \\
\hline ETAAS & $\begin{array}{c}\mathrm{EC}(\text { Ethanol, } 1: 5 \mathrm{m:v}) \\
\mathrm{Pd}\left(\mathrm{NO}_{3}\right)_{2}+\mathrm{Mg}\left(\mathrm{NO}_{3}\right)_{2} \\
\text { as modifier }\end{array}$ & $0.009 \mu \mathrm{g} \mathrm{g}^{-1}$ & $\begin{array}{c}0.010-0.194 \\
\mu g g^{-1}\end{array}$ & 110 \\
\hline $\begin{array}{l}\text { Anodic } \\
\text { stripping }\end{array}$ & $\begin{array}{c}\text { Mercury-film } \\
\text { electrode }\end{array}$ & $\begin{array}{c}4.6910^{-9} \\
\mathrm{~mol} \mathrm{~L}^{-1}\end{array}$ & n.d. & 165 \\
\hline
\end{tabular}




\begin{tabular}{|c|c|c|c|c|c|}
\hline & voltammetry & $\begin{array}{l}\text { Microemulsification } \\
\text { Standard addition } \\
\left(\mathrm{Cu}^{2+}\right)\end{array}$ & & & \\
\hline & $\begin{array}{l}\text { Anodic } \\
\text { stripping } \\
\text { voltammetry }\end{array}$ & $\begin{array}{c}\text { Bismuth film } \\
\text { electrode } \\
\text { Sample digestion } \\
\left(\mathrm{Cu}^{2+}\right)\end{array}$ & $12 \mathrm{ng} \mathrm{L}^{-1}$ & $\begin{array}{c}0.37-1.10 \\
\mathrm{mg} \mathrm{kg}^{-1}\end{array}$ & 166 \\
\hline \multirow[t]{5}{*}{$\mathrm{Fe}$} & ICP-OES & EC (Kerosene, 1:10) & $\begin{array}{c}0.011 \mathrm{mg} \\
\mathrm{kg}^{-1}\end{array}$ & $\begin{array}{c}0.104-17.12 \\
\mathrm{mg} \mathrm{kg}^{-1}\end{array}$ & 114 \\
\hline & ICP-OES & $\begin{array}{c}\text { EC (Ethanol, 1:10 for } \\
\text { vegetable oil and 1:20 } \\
\text { biodiesel) } \\
\text { IS: Y }\end{array}$ & $0.01 \mu \mathrm{g} \mathrm{g}^{-1}$ & $\begin{array}{c}0.78-21.2 \\
\mu g g^{-1}\end{array}$ & 5 \\
\hline & ICP-OES & $\begin{array}{l}\text { EC (1-Propanol, 1:10 } \\
\text { for vegetable oil and } \\
\text { 1:20 biodiesel) } \\
\text { IS: } Y\end{array}$ & $0.01 \mu \mathrm{g} \mathrm{g}^{-1}$ & $\begin{array}{c}0.78-21.2 \\
\mu g^{-1}\end{array}$ & 5 \\
\hline & ICP-OES & $\begin{array}{l}\text { EC (Aqueous } \\
\text { standards) } \\
\text { Emulsification }\end{array}$ & $0.01 \mu \mathrm{g} \mathrm{g}^{-1}$ & $\begin{array}{c}0.04-1.09 \\
\mu g^{-1}\end{array}$ & 123 \\
\hline & ICP-OES & $\begin{array}{l}\text { EC (Aqueous } \\
\text { standards) } \\
\text { Emulsification }\end{array}$ & $\begin{array}{c}0.006 \mathrm{mg} \\
\mathrm{kg}^{-1}\end{array}$ & $\begin{array}{c}0.029-2.200 \\
\mathrm{mg} \mathrm{kg}^{-1}\end{array}$ & 125 \\
\hline
\end{tabular}




\begin{tabular}{|c|c|c|c|c|c|}
\hline & & IS: Y & & & \\
\hline & ICP-MS & EC (Kerosene,1:3) & $\begin{array}{c}0.0869 \mu \mathrm{g} \\
\mathrm{kg}^{-1}\end{array}$ & $\begin{array}{c}4.61-50.8 \\
\mu g \mathrm{~kg}^{-1}\end{array}$ & 50 \\
\hline & $\begin{array}{l}\text { ETV-ICP-MS } \\
\text { (Pd as } \\
\text { modifier) }\end{array}$ & EC & $3 \mathrm{ng} \mathrm{g}^{-1}$ & $\begin{array}{c}120-375 \mathrm{ng} \\
\mathrm{g}^{-1}\end{array}$ & 93 \\
\hline & ETAAS & $\begin{array}{l}\text { EC (Treatment with } \\
\text { tetramethylammoniu } \\
\text { m hydroxide) } \\
0.1 \% \mathrm{Pd}+0.06 \% \mathrm{Mg}+ \\
0.06 \% \text { Triton } \mathrm{X}-100 \text { as } \\
\text { modifier }\end{array}$ & $24 \mathrm{ng} \mathrm{g}^{-1}$ & $\begin{array}{c}86-4940 \mathrm{ng} \\
g^{-1}\end{array}$ & 107 \\
\hline & ETAAS & $\begin{array}{c}\text { EC (Ethanol, 1:5 m:v) } \\
\mathrm{Pd}(\mathrm{NO} 3) 2+\mathrm{Mg}(\mathrm{NO} 3) 2 \\
\text { as modifier }\end{array}$ & $0.006 \mu \mathrm{g} \mathrm{g}^{-1}$ & $\begin{array}{c}0.023-5.18 \\
\mu g g^{-1}\end{array}$ & 110 \\
\hline $\mathrm{Hg}$ & ICP-MS & EC (Kerosene,1:3) & $\begin{array}{c}0.123 \mu \mathrm{g} \\
\mathrm{kg}^{-1}\end{array}$ & $\begin{array}{c}0.396-0.791 \\
\mu g \mathrm{~kg}^{-1}\end{array}$ & 50 \\
\hline & ETAAS & $\begin{array}{l}\text { Standard addition } \\
\text { Emulsification } \\
\text { Pd-Mg mixture as } \\
\text { modifier }\end{array}$ & $10.2 \mu \mathrm{g} \mathrm{kg}^{-1}$ & $23.2 \mu \mathrm{g} \mathrm{kg}^{-1}$ & 151 \\
\hline & FI-CV-AAS & Emulsification & $0.2 \mu \mathrm{g} \mathrm{kg}^{-1}$ & $\begin{array}{r}0.5-3.7 \mu g \\
k^{-1}\end{array}$ & 95 \\
\hline
\end{tabular}




\begin{tabular}{|c|c|c|c|c|c|}
\hline \multirow[t]{10}{*}{ K } & ICP-OES & EC (Kerosene, 1:4) & $7.1 \mu \mathrm{kg}^{-1}$ & $\begin{array}{c}5-10 \mathrm{mg} \mathrm{kg}^{-} \\
1\end{array}$ & 4 \\
\hline & ICP-OES & EC (Kerosene, 1:10) & $\begin{array}{c}0.070 \mathrm{mg} \\
\mathrm{kg}^{-1}\end{array}$ & $\begin{array}{c}2.059-32.46 \\
\mathrm{mg} \mathrm{kg}^{-1}\end{array}$ & 114 \\
\hline & ICP-OES & EC (Kerosene, 1:10) & $0.1 \mathrm{mg} \mathrm{kg}^{-1}$ & n.d. & 116 \\
\hline & ICP-OES & EC (Kerosene, 1:10) & $0.8 \mathrm{mg} \mathrm{kg}^{-1}$ & n.d. & 118 \\
\hline & ICP-OES & $\begin{array}{c}\text { EC (Ethanol, 1:10) } \\
\text { IS: } Y\end{array}$ & $0.3 \mu \mathrm{g} \mathrm{g}^{-1}$ & $\begin{array}{c}1.3-6.0 \mu g \\
g^{-1}\end{array}$ & 3 \\
\hline & ICP-OES & $\begin{array}{c}\text { EC (Ethanol, 1:10 for } \\
\text { vegetable oil and 1:20 } \\
\text { biodiesel) } \\
\text { IS: Y }\end{array}$ & $0.4 \mu \mathrm{g} \mathrm{g}^{-1}$ & $\begin{array}{c}17.5-189 \mu g \\
g^{-1}\end{array}$ & 5 \\
\hline & ICP-OES & $\begin{array}{l}\text { EC (1-Propanol, 1:10 } \\
\text { for vegetable oil and } \\
\text { 1:20 biodiesel) } \\
\text { IS: Y }\end{array}$ & $0.2 \mu \mathrm{g} \mathrm{g}^{-1}$ & $\begin{array}{c}17.5-189 \mu g \\
g^{-1}\end{array}$ & 5 \\
\hline & ICP-OES & $\begin{array}{l}\text { EC (Aqueous } \\
\text { standards) } \\
\text { Emulsification } \\
\text { IS: Y }\end{array}$ & $\begin{array}{c}0.241 \mathrm{mg} \\
\mathrm{kg}^{-1}\end{array}$ & n.d. & 125 \\
\hline & ICP-OES & $\begin{array}{c}\text { EC (Open digestion) } \\
\text { IS: } Y\end{array}$ & $0.11 \mu \mathrm{g} \mathrm{g}^{-1}$ & $\begin{array}{c}2.1-7.3 \mu g \\
g^{-1}\end{array}$ & 126 \\
\hline & ICP-OES & EC (Microwave close & $0.16 \mu \mathrm{g} \mathrm{g}^{-1}$ & $2.1-7.3 \mu \mathrm{g}$ & 126 \\
\hline
\end{tabular}




\begin{tabular}{|c|c|c|c|c|}
\hline & $\begin{array}{l}\text { digestion) } \\
\text { IS: Y }\end{array}$ & & $\mathrm{g}^{-1}$ & \\
\hline ICP-MS & EC (Kerosene,1:3) & $2.10 \mu \mathrm{g} \mathrm{kg}^{-1}$ & $\begin{array}{c}15.4-50.6 \\
\mu g \mathrm{~kg}^{-1}\end{array}$ & 50 \\
\hline FAES & $\begin{array}{c}\text { EC } \\
\text { Microemulsification }\end{array}$ & $\begin{array}{c}0.06-0.09 \\
\mu g^{-1}\end{array}$ & $\begin{array}{c}2.00-63.76 \\
\mu g g^{-1}\end{array}$ & 144 \\
\hline FAES & $\begin{array}{c}\text { EC (Ethanol, } 1: 10 \text { and } \\
1: 20)\end{array}$ & $\begin{array}{c}0.60 \mathrm{mg} \mathrm{kg}^{-1} \\
(1: 10) \\
1.08 \mathrm{mg} \mathrm{kg}^{-1} \\
(1: 20)\end{array}$ & n.d. & 106 \\
\hline FAAS & 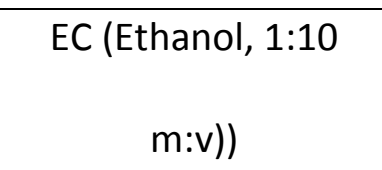 & $\begin{array}{c}0.17 \mathrm{mg} \\
\mathrm{kg}^{-1}\end{array}$ & $\begin{array}{c}2.7-7.2 \mathrm{mg} \\
\mathrm{kg}^{-1}\end{array}$ & 148 \\
\hline FAAS & $\begin{array}{c}\text { EC (Aqueous } \\
\text { standards) } \\
\text { Microemulsification }\end{array}$ & $0.06 \mu g^{-1}$ & $\begin{array}{c}0.71-36.2 \\
\mathrm{mg} \mathrm{kg}^{-1}\end{array}$ & 90 \\
\hline FAAS & $\begin{array}{c}\text { EC } \\
\text { Microemulsification }\end{array}$ & $0.01 \mu \mathrm{g} \mathrm{g}^{-1}$ & $\begin{array}{c}0.13-2.30 \\
\mu g g^{-1}\end{array}$ & 109 \\
\hline IC & $\mathrm{EC}\left(\mathrm{K}^{+}\right)$ & $0.42 \mathrm{mg} \mathrm{kg}^{-1}$ & $\begin{array}{c}0.35-0.91 \\
\mathrm{mg} \mathrm{kg}^{-1}\end{array}$ & 160 \\
\hline $\begin{array}{l}\text { CE + Diode } \\
\text { array detector }\end{array}$ & $\begin{array}{c}\text { IS } \\
\text { Liquid-liquid } \\
\text { extraction } \\
\left(\mathrm{K}^{+}\right)\end{array}$ & $0.3 \mathrm{mg} \mathrm{kg}^{-1}$ & $\begin{array}{c}1.1-16.8 \mathrm{mg} \\
\mathrm{kg}^{-1}\end{array}$ & 162 \\
\hline
\end{tabular}




\begin{tabular}{|c|c|c|c|c|}
\hline $\begin{array}{l}\text { CE + Coupled } \\
\text { contactless } \\
\text { conductivity } \\
\text { detector }\end{array}$ & $\begin{array}{l}\text { Liquid-liquid } \\
\text { extraction } \\
\left(\mathrm{K}^{+}\right)\end{array}$ & $0.12 \mathrm{mg} \mathrm{L}^{-1}$ & $\begin{array}{c}0.46-0.61 \\
m g ~ k g^{-1}\end{array}$ & 163 \\
\hline Voltammetry & $\begin{array}{c}\text { Glassy } \\
\text { carbon electrode } \\
\text { modified with } \\
\text { nickel(II) } \\
\text { hexacyanoferrate } \\
\text { nanoparticles } \\
\text { Microemulsification } \\
\text { Standard addition }\left(\mathrm{K}^{+}\right)\end{array}$ & $\begin{array}{c}5.010-5 \\
\mathrm{~mol} \mathrm{~L}^{-1}\end{array}$ & $12.9 \mathrm{mg} \mathrm{kg}^{-1}$ & 167 \\
\hline Voltammetry & $\begin{array}{c}\text { Nickel } \\
\text { hexacyanoferrate- } \\
\text { modified electrode } \\
\text { Liquid-liquid } \\
\text { extraction }\left(\mathrm{K}^{+}\right) \\
\text {Standard addition }\end{array}$ & $\begin{array}{l}1.910-5 \\
\mathrm{~mol} \mathrm{~L}^{-1}\end{array}$ & $0.96 \mathrm{mg} \mathrm{kg}^{-1}$ & 168 \\
\hline HR-CS FAAS & EC (Xylene, 1:10 m:v) & $\begin{array}{c}0.023 \mathrm{mg} \\
\mathrm{kg}^{-1}\end{array}$ & $\begin{array}{c}9.20-10.00 \\
\mathrm{mg} \mathrm{kg}^{-1}\end{array}$ & 145 \\
\hline LS FAAS & EC (Xylene, 1:10 m:v) & $0.57 \mathrm{mg} \mathrm{kg}^{-1}$ & $\begin{array}{c}9.20-10.00 \\
\mathrm{mg} \mathrm{kg}^{-1}\end{array}$ & 145 \\
\hline WCAES & Tungsten coil & $70-80 \mu \mathrm{g} \mathrm{kg}^{-}$ & $10.8-95.6$ & 170 \\
\hline
\end{tabular}




\begin{tabular}{|c|c|c|c|c|c|}
\hline & & $\begin{array}{c}\text { atomizer } \\
\text { Standard addition }\end{array}$ & 1 & $\begin{array}{l}\mathrm{mg} \mathrm{kg}^{-} \\
1\end{array}$ & \\
\hline \multirow[t]{8}{*}{$\mathrm{Mg}$} & ICP-OES & EC (Kerosene, 1:4) & $\begin{array}{c}0.9-39 \mu g \\
\mathrm{~kg}^{-1}\end{array}$ & $\begin{array}{c}1-10 \mathrm{mg} \mathrm{kg}^{-} \\
1\end{array}$ & 4 \\
\hline & ICP-OES & EC (Kerosene, 1:10) & $\begin{array}{c}0.009 \mathrm{mg} \\
\mathrm{kg}^{-1}\end{array}$ & $\begin{array}{c}0.353-27.31 \\
\mathrm{mg} \mathrm{kg}^{-1}\end{array}$ & 114 \\
\hline & ICP-OES & EC (Kerosene, 1:10) & $0.01 \mathrm{mg} \mathrm{kg}^{-1}$ & $\begin{array}{c}0.63-3.6 \mathrm{mg} \\
\mathrm{kg}^{-1}\end{array}$ & 116 \\
\hline & ICP-OES & EC (Kerosene, 1:10) & $0.02 \mathrm{mg} \mathrm{kg}^{-1}$ & $\begin{array}{c}0.10-22.1 \\
\mathrm{mg} \mathrm{kg}^{-1}\end{array}$ & 118 \\
\hline & ICP-OES & $\begin{array}{c}\text { EC (Ethanol, 1:10) } \\
\text { IS: } Y\end{array}$ & $0.005 \mu \mathrm{g} \mathrm{g}^{-1}$ & $\begin{array}{c}0.058-5.9 \\
\mu g g^{-1}\end{array}$ & 3 \\
\hline & ICP-OES & $\begin{array}{c}\text { EC (Ethanol, 1:10 for } \\
\text { vegetable oil and 1:20 } \\
\text { biodiesel) } \\
\text { IS: Y }\end{array}$ & $0.001 \mu \mathrm{g} \mathrm{g}^{-1}$ & $\begin{array}{c}0.06-33.80 \\
\mu g g^{-1}\end{array}$ & 5 \\
\hline & ICP-OES & $\begin{array}{l}\text { EC (1-Propanol, 1:10 } \\
\text { for vegetable oil and } \\
\text { 1:20 biodiesel) } \\
\qquad \text { IS: Y }\end{array}$ & $0.001 \mu \mathrm{g} \mathrm{g}^{-1}$ & $\begin{array}{c}0.06-33.80 \\
\mu g g^{-1}\end{array}$ & 5 \\
\hline & ICP-OES & $\begin{array}{l}\text { EC (Aqueous } \\
\text { standards) } \\
\text { Emulsification }\end{array}$ & $0.002 \mu \mathrm{g} \mathrm{g}^{-1}$ & $\begin{array}{c}0.007-1.08 \\
\mu g g^{-1}\end{array}$ & 123 \\
\hline
\end{tabular}




\begin{tabular}{|c|c|c|c|c|}
\hline ICP-OES & $\begin{array}{c}\text { EC (Aqueous } \\
\text { standards) } \\
\text { Emulsification } \\
\text { IS: Y }\end{array}$ & $\begin{array}{c}0.006 \mathrm{mg} \\
\mathrm{kg}^{-1}\end{array}$ & $\begin{array}{c}0.030-0.033 \\
\mathrm{mg} \mathrm{kg}^{-1}\end{array}$ & 125 \\
\hline ICP-OES & $\begin{array}{c}\text { EC (Open digestion) } \\
\text { IS: Y }\end{array}$ & $0.04 \mu g^{-1}$ & n.d. & 126 \\
\hline ICP-OES & $\begin{array}{c}\text { EC (Microwave close } \\
\text { digestion) } \\
\text { IS: Y }\end{array}$ & $0.03 \mu \mathrm{g} \mathrm{g}^{-1}$ & n.d. & 126 \\
\hline ICP-MS & EC (Kerosene,1:3) & $8.65 \mu \mathrm{g} \mathrm{kg}^{-1}$ & $\begin{array}{c}6.16-12.1 \\
\mu g \mathrm{~kg}^{-1}\end{array}$ & 50 \\
\hline FAAS & $\begin{array}{c}\text { EC (Ethanol, 1:10 } \\
\mathrm{m:v}))\end{array}$ & $\begin{array}{c}0.05 \mathrm{mg} \\
\mathrm{kg}^{-1}\end{array}$ & $0.068 \mathrm{mg} \mathrm{kg}^{-1}$ & 148 \\
\hline FAAS & $\begin{array}{c}\text { EC } \\
\text { Microemulsification }\end{array}$ & $0.03 \mathrm{mg} \mathrm{L}^{-1}$ & n.d. & 149 \\
\hline FAAS & $\begin{array}{c}\text { EC } \\
\text { Microemulsification }\end{array}$ & $0.004 \mu \mathrm{g} \mathrm{g}^{-1}$ & $\begin{array}{c}0.041-0.52 \\
\mu g g^{-1}\end{array}$ & 109 \\
\hline IC & $\mathrm{EC}\left(\mathrm{Mg}^{2+}\right)$ & $0.36 \mathrm{mg} \mathrm{kg}^{-1}$ & $\begin{array}{c}0.06-0.93 \\
\mathrm{mg} \mathrm{kg}^{-1}\end{array}$ & 160 \\
\hline $\begin{array}{c}\text { CE + Diode } \\
\text { array detector }\end{array}$ & $\begin{array}{c}\text { IS } \\
\text { Liquid-liquid } \\
\text { extraction } \\
\left(\mathrm{Mg}^{2+}\right)\end{array}$ & $0.3 \mathrm{mg} \mathrm{kg}^{-1}$ & n.d. & 162 \\
\hline
\end{tabular}




\begin{tabular}{|c|c|c|c|c|c|}
\hline \multirow[t]{3}{*}{ 更 } & $\begin{array}{l}\text { CE + Coupled } \\
\text { contactless } \\
\text { conductivity } \\
\text { detector }\end{array}$ & $\begin{array}{l}\text { Liquid-liquid } \\
\text { extraction } \\
\qquad\left(\mathrm{Mg}^{2+}\right)\end{array}$ & $0.07 \mathrm{mg} \mathrm{L}^{-1}$ & $0.28 \mathrm{mg} \mathrm{kg}^{-1}$ & 163 \\
\hline & HR-CS FAAS & EC (Xylene, 1:10 m:v) & $\begin{array}{c}0.057 \mathrm{mg} \\
\mathrm{kg}^{-1}\end{array}$ & $\begin{array}{c}0.47-0.59 \\
\mathrm{mg} \mathrm{kg}^{-1}\end{array}$ & 145 \\
\hline & LS FAAS & EC (Xylene, 1:10 m:v) & $0.11 \mathrm{mg} \mathrm{kg}^{-1}$ & $\begin{array}{c}0.47-0.59 \\
\mathrm{mg} \mathrm{kg}^{-1}\end{array}$ & 145 \\
\hline \multirow[t]{5}{*}{$\mathrm{Mn}$} & ICP-OES & $\begin{array}{l}\text { EC (Aqueous } \\
\text { standards) } \\
\text { Emulsification }\end{array}$ & $0.005 \mu \mathrm{g} \mathrm{g}^{-1}$ & $\begin{array}{c}1.00-1.08 \\
\mu g^{-1}\end{array}$ & 123 \\
\hline & ICP-OES & $\begin{array}{c}\text { EC (Aqueous } \\
\text { standards) } \\
\text { Emulsification } \\
\text { IS: Y }\end{array}$ & $\begin{array}{c}0.001 \mathrm{mg} \\
\mathrm{kg}^{-1}\end{array}$ & $0.001 \mathrm{mg} \mathrm{kg}^{-1}$ & 125 \\
\hline & ICP-MS & EC (Kerosene,1:3) & $\begin{array}{c}0.0563 \mu \mathrm{g} \\
\mathrm{kg}^{-1}\end{array}$ & $\begin{array}{c}0.114- \\
0.450 \mu \mathrm{g} \mathrm{kg}^{-1}\end{array}$ & 50 \\
\hline & ICP-MS & $\begin{array}{c}\text { EC (Aqueous } \\
\text { standards) } \\
\text { Microemulsification }\end{array}$ & $\begin{array}{c}7.5110^{-1} \mu \mathrm{g} \\
\mathrm{L}^{-1}\end{array}$ & $\begin{array}{c}<0.75-1.23 \\
\mu g \mathrm{~L}^{-1}\end{array}$ & 111 \\
\hline & ICP-MS & EC & $\begin{array}{l}\text { Room } \\
\text { temperatur } \\
\text { e (Spray }\end{array}$ & $\begin{array}{c}0.22-0.24 \\
\mu g \mathrm{~L}^{-1}\end{array}$ & 133 \\
\hline
\end{tabular}




\begin{tabular}{|c|c|c|c|c|c|}
\hline & & & $\begin{array}{l}\text { chamber): } \\
0.31 \mathrm{ng} \mathrm{mL}^{-1} \\
110 \circ \mathrm{C} \\
\text { (Spray } \\
\text { chamber): } \\
0.06 \mathrm{ng} \mathrm{mL}^{-1} \\
200 \circ \mathrm{C} \\
\text { (Spray } \\
\text { chamber): } \\
0.23 \mathrm{ng} \mathrm{mL}^{-1}\end{array}$ & & \\
\hline & $\begin{array}{l}\text { ETV-ICP-MS } \\
\text { (Pd as } \\
\text { modifier) }\end{array}$ & EC & $0.3 \mathrm{ng} \mathrm{g}^{-1}$ & $4.9-76 \mathrm{ng} \mathrm{g}^{-1}$ & 93 \\
\hline & ETAAS & $\begin{array}{c}\mathrm{EC}(\text { Ethanol, } 1: 5 \mathrm{~m}: \mathrm{v}) \\
\mathrm{Pd}\left(\mathrm{NO}_{3}\right)_{2}+\mathrm{Mg}\left(\mathrm{NO}_{3}\right)_{2} \\
\text { as modifier }\end{array}$ & $0.003 \mu \mathrm{g} \mathrm{g}^{-1}$ & $\begin{array}{c}0.004-0.037 \\
\mu g g^{-1}\end{array}$ & 110 \\
\hline Mo & ICP-MS & EC (Kerosene,1:3) & $\begin{array}{c}0.371 \mu \mathrm{g} \\
\mathrm{kg}^{-1}\end{array}$ & n.d. & 50 \\
\hline \multirow[t]{3}{*}{$\mathrm{Na}$} & ICP-OES & EC (Kerosene, 1:4) & $\begin{array}{c}1.4-1.6 \mu g \\
\mathrm{~kg}^{-1}\end{array}$ & $2-10 \mathrm{mg} \mathrm{kg}^{-1}$ & 4 \\
\hline & ICP-OES & EC (Kerosene, 1:10) & $\begin{array}{c}0.019 \mathrm{mg} \\
\mathrm{kg}^{-1}\end{array}$ & $\begin{array}{c}1.414-21.59 \\
\mathrm{mg} \mathrm{kg}^{-1}\end{array}$ & 114 \\
\hline & ICP-OES & EC (Kerosene, 1:10) & $0.1 \mathrm{mg} \mathrm{kg}^{-1}$ & $0.6-23 \mathrm{mg}$ & 116 \\
\hline
\end{tabular}




\begin{tabular}{|c|c|c|c|c|}
\hline & & & $\mathrm{kg}^{-1}$ & \\
\hline ICP-OES & EC (Kerosene, 1:10) & $0.2 \mathrm{mg} \mathrm{kg}^{-1}$ & $\begin{array}{c}0.23-13.8 \\
\mathrm{mg} \mathrm{kg}^{-1}\end{array}$ & 118 \\
\hline ICP-OES & $\begin{array}{c}\text { EC (Ethanol, 1:10) } \\
\text { IS: Y }\end{array}$ & $0.1 \mu g^{-1}$ & $\begin{array}{c}1.4-44.3 \mu g \\
g^{-1}\end{array}$ & 3 \\
\hline ICP-OES & $\begin{array}{c}\text { EC (Ethanol, 1:10 for } \\
\text { vegetable oil and 1:20 } \\
\text { biodiesel) } \\
\text { IS: Y }\end{array}$ & $0.1 \mu \mathrm{g} \mathrm{g}^{-1}$ & $\begin{array}{c}0.9-29.0 \mu g \\
g^{-1}\end{array}$ & 5 \\
\hline ICP-OES & $\begin{array}{l}\text { EC (1-Propanol, 1:10 } \\
\text { for vegetable oil and } \\
\text { 1:20 biodiesel) } \\
\text { IS: Y }\end{array}$ & $0.1 \mu \mathrm{g} \mathrm{g}^{-1}$ & $\begin{array}{c}0.9-29.0 \mu g \\
g^{-1}\end{array}$ & 5 \\
\hline ICP-OES & $\begin{array}{l}\text { EC (Aqueous } \\
\text { standards) } \\
\text { Emulsification }\end{array}$ & $0.04 \mu \mathrm{g} \mathrm{g}^{-1}$ & $\begin{array}{c}0.14-1.08 \\
\mu g g^{-1}\end{array}$ & 123 \\
\hline ICP-OES & $\begin{array}{l}\text { EC (Aqueous } \\
\text { standards) } \\
\text { Emulsification } \\
\text { IS: Y }\end{array}$ & $\begin{array}{c}0.071 \mathrm{mg} \\
\mathrm{kg}^{-1}\end{array}$ & $\begin{array}{c}0.022-1.490 \\
\mathrm{mg} \mathrm{kg}^{-1}\end{array}$ & 125 \\
\hline ICP-OES & $\begin{array}{c}\text { EC (Open digestion) } \\
\text { IS: } Y\end{array}$ & $0.56 \mu \mathrm{g} \mathrm{g}^{-1}$ & $\begin{array}{c}6.5-7.6 \mu g \\
g^{-1}\end{array}$ & 126 \\
\hline ICP-OES & EC (Microwave close & $0.16 \mu \mathrm{g} \mathrm{g}^{-1}$ & $6.5-7.6 \mu \mathrm{g}$ & 126 \\
\hline
\end{tabular}




\begin{tabular}{|c|c|c|c|c|}
\hline & $\begin{array}{l}\text { digestion) } \\
\text { IS: Y }\end{array}$ & & $\mathrm{g}^{-1}$ & \\
\hline ICP-MS & EC (Kerosene,1:3) & $1.19 \mu \mathrm{g} \mathrm{kg}^{-1}$ & $\begin{array}{c}127-1430 \mu g \\
k^{-1}\end{array}$ & 50 \\
\hline FAES & $\begin{array}{c}\text { EC } \\
\text { Microemulsification }\end{array}$ & $\begin{array}{c}0.08-0.10 \\
\mu g^{-1}\end{array}$ & $\begin{array}{c}3.60-3.73 \\
\mu g g^{-1}\end{array}$ & 144 \\
\hline FAES & $\begin{array}{c}\text { EC (Ethanol, } 1: 10 \text { and } \\
1: 20)\end{array}$ & $\begin{array}{c}0.65 \mathrm{mg} \mathrm{kg}^{-1} \\
(1: 10) \\
1.20 \mathrm{mg} \mathrm{kg}^{-1} \\
(1: 20)\end{array}$ & n.d. & 106 \\
\hline FAAS & 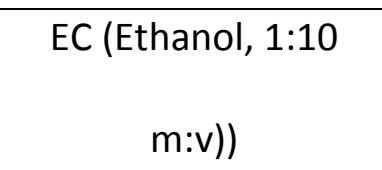 & $\begin{array}{c}0.14 \mathrm{mg} \\
\mathrm{kg}^{-1}\end{array}$ & $\begin{array}{c}0.60-2.70 \\
\mathrm{mg} \mathrm{kg}^{-1}\end{array}$ & 148 \\
\hline FAAS & $\begin{array}{c}\text { EC (Aqueous } \\
\text { standards) } \\
\text { Microemulsification }\end{array}$ & $0.1 \mu \mathrm{g} \mathrm{g}^{-1}$ & $\begin{array}{c}0.5-39.7 \mathrm{mg} \\
\mathrm{kg}^{-1}\end{array}$ & 90 \\
\hline FAAS & $\begin{array}{c}\text { EC } \\
\text { Microemulsification }\end{array}$ & $0.1 \mu g^{-1}$ & $\begin{array}{c}1.18-1.51 \\
\mu g g^{-1}\end{array}$ & 109 \\
\hline IC & $\mathrm{EC}\left(\mathrm{Na}^{+}\right)$ & $0.11 \mathrm{mg} \mathrm{kg}^{-1}$ & $\begin{array}{c}0.99-3.56 \\
\mathrm{mg} \mathrm{kg}^{-1}\end{array}$ & 160 \\
\hline $\begin{array}{c}\text { CE + Diode } \\
\text { array detector }\end{array}$ & $\begin{array}{c}\text { IS } \\
\text { Liquid-liquid } \\
\text { extraction } \\
\left(\mathrm{Na}^{+}\right)\end{array}$ & $0.3 \mathrm{mg} \mathrm{kg}^{-1}$ & $\begin{array}{c}2.3-39.6 \mathrm{mg} \\
\mathrm{kg}^{-1}\end{array}$ & 162 \\
\hline
\end{tabular}




\begin{tabular}{|c|c|c|c|c|c|}
\hline & $\begin{array}{l}\text { CE + Coupled } \\
\text { contactless } \\
\text { conductivity } \\
\text { detector }\end{array}$ & $\begin{array}{l}\text { Liquid-liquid } \\
\text { extraction } \\
\left(\mathrm{Na}^{+}\right)\end{array}$ & $0.14 \mathrm{mg} \mathrm{L}^{-1}$ & $0.97 \mathrm{mg} \mathrm{kg}^{-1}$ & 163 \\
\hline & HR-CS FAAS & EC (Xylene, 1:10 m:v) & $0.10 \mathrm{mg} \mathrm{kg}^{-1}$ & $\begin{array}{c}0.54-0.98 \\
\mathrm{mg} \mathrm{kg}^{-1}\end{array}$ & 145 \\
\hline & LS FAAS & EC (Xylene, 1:10 m:v) & $0.23 \mathrm{mg} \mathrm{kg}^{-1}$ & $\begin{array}{c}0.54-0.98 \\
\mathrm{mg} \mathrm{kg}^{-1}\end{array}$ & 145 \\
\hline & WCAES & $\begin{array}{c}\text { Tungsten coil } \\
\text { atomizer } \\
\text { Standard addition }\end{array}$ & $20 \mu \mathrm{gg}^{-1}$ & $\begin{array}{c}6.08-41.3 \\
\mathrm{mg} \mathrm{kg}^{-} \\
1\end{array}$ & 170 \\
\hline $\mathrm{Ni}$ & ICP-OES & EC (Kerosene, 1:10) & $\begin{array}{c}0.006 \mathrm{mg} \\
\mathrm{kg}^{-1}\end{array}$ & $\begin{array}{c}0.220-0.948 \\
\mathrm{mg} \mathrm{kg}^{-1}\end{array}$ & 114 \\
\hline & ICP-MS & EC (Kerosene,1:3) & $\begin{array}{c}0.126 \mu \mathrm{g} \\
\mathrm{kg}^{-1}\end{array}$ & $\begin{array}{c}0.397-3.64 \\
\mu g \mathrm{~kg}^{-1}\end{array}$ & 50 \\
\hline & ICP-MS & $\begin{array}{c}\text { EC (Aqueous } \\
\text { standards) } \\
\text { Microemulsification }\end{array}$ & $\begin{array}{c}19.3-19.5 \\
\mu g L^{-1}\end{array}$ & n.d. & 111 \\
\hline & ICP-MS & EC & $\begin{array}{c}\text { Room } \\
\text { temperatur } \\
\text { e (Spray } \\
\text { chamber): } \\
0.22 \mathrm{ng} \mathrm{mL}^{-1}\end{array}$ & $\begin{array}{c}1.15-1.17 \\
\mu g \mathrm{~L}^{-1}\end{array}$ & 133 \\
\hline
\end{tabular}




\begin{tabular}{|c|c|c|c|c|c|}
\hline & & & $\begin{array}{c}110^{\circ} \mathrm{C} \\
\text { (Spray } \\
\text { chamber): } \\
0.07 \mathrm{ng} \mathrm{mL}^{-1} \\
200^{\circ} \mathrm{C} \\
\text { (Spray } \\
\text { chamber): } \\
0.18 \mathrm{ng} \mathrm{mL}^{-1}\end{array}$ & & \\
\hline & $\begin{array}{l}\text { ETV-ICP-MS } \\
\text { (Pd as } \\
\text { modifier) }\end{array}$ & EC & $0.5 \mathrm{ng} \mathrm{g}^{-1}$ & $\begin{array}{c}6.5-14.1 \mathrm{ng} \\
\mathrm{g}^{-1}\end{array}$ & 93 \\
\hline & ETAAS & $\begin{array}{c}\text { EC } \\
\text { Microemulsification } \\
\text { W as modifier }\end{array}$ & $0.9 \mu \mathrm{g} \mathrm{L}^{-1}$ & $\begin{array}{c}0.2-2.4 \mu g \\
g^{-1}\end{array}$ & 91 \\
\hline \multirow[t]{5}{*}{$P$} & ICP-OES & EC (Kerosene, 1:4) & $\begin{array}{c}32-67 \mu g \\
k g^{-1}\end{array}$ & n.d. & 4 \\
\hline & ICP-OES & EC (Kerosene, 1:10) & $\begin{array}{c}0.023 \mathrm{mg} \\
\mathrm{kg}^{-1}\end{array}$ & $\begin{array}{c}0.799-223.8 \\
\mathrm{mg} \mathrm{kg}^{-1}\end{array}$ & 114 \\
\hline & ICP-OES & EC (Kerosene, 1:10) & $0.09 \mathrm{mg} \mathrm{kg}^{-1}$ & $\begin{array}{c}1.2-7.6 \mathrm{mg} \\
\mathrm{kg}^{-1}\end{array}$ & 116 \\
\hline & ICP-OES & EC (Kerosene, 1:10) & $0.4 \mathrm{mg} \mathrm{kg}^{-1}$ & $\begin{array}{c}0.07-26.3 \\
\mathrm{mg} \mathrm{kg}^{-1}\end{array}$ & 118 \\
\hline & ICP-OES & EC (Ethanol, 1:10) & $0.5 \mu \mathrm{g} \mathrm{g}^{-1}$ & $2.8-7.9 \mu \mathrm{g}$ & 3 \\
\hline
\end{tabular}




\begin{tabular}{|c|c|c|c|c|}
\hline & IS: Y & & $\mathrm{g}^{-1}$ & \\
\hline ICP-OES & $\begin{array}{c}\text { EC (Ethanol, 1:10 for } \\
\text { vegetable oil and 1:20 } \\
\text { biodiesel) } \\
\text { IS: Y }\end{array}$ & $0.1 \mu \mathrm{g} \mathrm{g}^{-1}$ & $\begin{array}{c}0.6-321.0 \\
\mu g g^{-1}\end{array}$ & 5 \\
\hline ICP-OES & $\begin{array}{c}\text { EC (1-Propanol, 1:10 } \\
\text { for vegetable oil and } \\
\text { 1:20 biodiesel) } \\
\text { IS: Y }\end{array}$ & $0.1 \mu \mathrm{g} \mathrm{g}^{-1}$ & $\begin{array}{c}0.6-321.0 \\
\mu g g^{-1}\end{array}$ & 5 \\
\hline ICP-OES & $\begin{array}{c}\text { EC (Aqueous } \\
\text { standards) } \\
\text { Emulsification }\end{array}$ & $0.20 \mu \mathrm{g} \mathrm{g}^{-1}$ & $\begin{array}{c}0.96-1.09 \mu g \\
g^{-1}\end{array}$ & 123 \\
\hline ICP-OES & $\begin{array}{c}\text { EC (Open digestion) } \\
\text { IS: } Y\end{array}$ & $0.22 \mu \mathrm{g} \mathrm{g}^{-1}$ & n.d. & 126 \\
\hline ICP-OES & $\begin{array}{l}\text { EC (Microwave close } \\
\text { digestion) } \\
\text { IS: Y }\end{array}$ & $0.40 \mu \mathrm{g} \mathrm{g}^{-1}$ & n.d. & 126 \\
\hline ICP-MS & EC (Kerosene,1:3) & $22.7 \mu \mathrm{gg}^{-1}$ & $\begin{array}{c}21.4-2120 \\
\mu g \mathrm{~kg}^{-1}\end{array}$ & 50 \\
\hline $\begin{array}{l}\text { ETV-ICP-MS } \\
\text { (Tungsten coil } \\
\text { electrothermal } \\
\text { matrix }\end{array}$ & EC & $0.4 \mathrm{mg} \mathrm{kg}^{-1}$ & $\begin{array}{c}0.51-5.75 \\
m g ~ k g\end{array}$ & 139 \\
\hline
\end{tabular}




\begin{tabular}{|c|c|c|c|c|c|}
\hline & $\begin{array}{c}\text { decomposition } \\
\text { l }\end{array}$ & & & & \\
\hline & ETAAS & $\begin{array}{l}\text { EC (Direct sampling) } \\
20 \mu \mathrm{L} \text { of } \mathrm{Pd}(1000 \mu \mathrm{g} \\
\left.\mathrm{mL}^{-1}\right) \text { in } 0.1 \% \mathrm{HNO} 3 \\
\text { and } 0.025 \% \text { Triton } \mathrm{X}- \\
100 \text { as modifier }\end{array}$ & $1.2 \mu \mathrm{g} \mathrm{g}^{-1}$ & $\begin{array}{c}2.4-4.5 \mu g g^{-} \\
1\end{array}$ & 156 \\
\hline & ETAAS & $\begin{array}{c}\text { EC (Direct sampling) } \\
30 \mu \mathrm{gd}\left(\mathrm{NO}_{3}\right)_{2}+20 \mu \mathrm{g} \\
\mathrm{Mg}\left(\mathrm{NO}_{3}\right)_{2} \text { mixture } \\
\text { dissolved in } 0.2 \% \\
\mathrm{HNO}_{3} \text { and } 0.1 \% \text { Triton } \\
\mathrm{X}-100 \text { as modifier }\end{array}$ & $0.5 \mu \mathrm{g} \mathrm{g}^{-1}$ & $\begin{array}{c}4.2-4.86 \\
\mathrm{mg} \mathrm{kg}^{-1}\end{array}$ & 158 \\
\hline & IC & $\mathrm{EC}\left(\mathrm{PO}_{4}{ }^{3-}\right)$ & $0.1 \mathrm{mg} \mathrm{kg}^{-1}$ & $\begin{array}{c}33-417 \mathrm{mg} \\
\mathrm{kg}^{-1}\end{array}$ & 161 \\
\hline & $\begin{array}{l}\text { Cyclic } \\
\text { voltammetry }\end{array}$ & $\begin{array}{c}\text { 1:12 } \\
\text { Phosphomolybdic } \\
\text { modified electrode } \\
\text { Liquid-liquid } \\
\text { extraction } \\
\text { Standard addition }\end{array}$ & $\begin{array}{c}8.710-6 \\
\mathrm{~mol} \mathrm{~L}^{-1}\end{array}$ & $1.36 \mathrm{mg} \mathrm{kg}^{-1}$ & 164 \\
\hline $\mathrm{Pb}$ & ICP-MS & EC (Kerosene,1:3) & $\begin{array}{c}0.0226 \mu g \\
k^{-1}\end{array}$ & $\begin{array}{c}0.0450- \\
0.385 \mu g k^{-1}\end{array}$ & 50 \\
\hline
\end{tabular}




\begin{tabular}{|c|c|c|c|c|c|}
\hline & ICP-MS & $\begin{array}{c}\text { EC (Aqueous } \\
\text { standards) } \\
\text { Microemulsification }\end{array}$ & $\begin{array}{c}1.4910^{-1} \mu g \\
L^{-1}\end{array}$ & $\begin{array}{c}<0.15-0.401 \\
\mu \mathrm{g} \mathrm{L}^{-1}\end{array}$ & 111 \\
\hline & $\begin{array}{l}\text { Anodic } \\
\text { stripping } \\
\text { voltammetry }\end{array}$ & $\begin{array}{c}\text { Mercury- film } \\
\text { electrode } \\
\text { Microemulsification } \\
\text { Standard addition } \\
\left(\mathrm{Pb}^{2+}\right)\end{array}$ & $\begin{array}{c}2.91 \text { 10-9 } \\
\mathrm{mol} \mathrm{L}^{-1}\end{array}$ & n.d. & 165 \\
\hline & $\begin{array}{l}\text { Anodic } \\
\text { stripping } \\
\text { voltammetry }\end{array}$ & $\begin{array}{c}\text { Bismuth film } \\
\text { electrode } \\
\text { Sample digestion } \\
\left(\mathrm{Pb}^{2+}\right)\end{array}$ & $8 \mathrm{ng} \mathrm{L}^{-1}$ & $\begin{array}{c}0.39-2.20 \mathrm{mg} \\
\mathrm{kg}^{-1}\end{array}$ & 166 \\
\hline S & ICP-OES & EC (Kerosene, 1:10) & $0.01 \mathrm{mg} \mathrm{kg}^{-1}$ & $\begin{array}{c}0.6-0.9 \mathrm{mg} \\
\mathrm{kg}^{-1}\end{array}$ & 116 \\
\hline & ICP-OES & $\begin{array}{c}\text { EC (Ethanol, 1:10 for } \\
\text { vegetable oil and 1:20 } \\
\text { biodiesel) } \\
\text { IS: Y }\end{array}$ & $0.4 \mu \mathrm{g} \mathrm{g}^{-1}$ & $\begin{array}{c}1.4-817 \mu g \\
g^{-1}\end{array}$ & 5 \\
\hline & ICP-OES & $\begin{array}{l}\text { EC (1-Propanol, 1:10 } \\
\text { for vegetable oil and } \\
\text { 1:20 biodiesel) } \\
\text { IS: } Y\end{array}$ & $0.3 \mu \mathrm{g} \mathrm{g}^{-1}$ & $\begin{array}{c}1.4-817 \mu g \\
g^{-1}\end{array}$ & 5 \\
\hline & ICP-OES & EC (Aqueous & $0.21-0.80$ & $2-7 \mathrm{mg} \mathrm{L}^{-1}$ & 124 \\
\hline
\end{tabular}




\begin{tabular}{|c|c|c|c|c|c|}
\hline & & $\begin{array}{c}\text { standards) } \\
\text { Microemulsification }\end{array}$ & $\mathrm{mg} \mathrm{L}^{-1}$ & & \\
\hline & ICP-MS & EC (Kerosene,1:3) & $\begin{array}{c}0.0293 \mu \mathrm{g} \\
\mathrm{kg}^{-1}\end{array}$ & $\begin{array}{c}1.29-18.9 \\
\mathrm{mg} \mathrm{kg}^{-1}\end{array}$ & 50 \\
\hline & SF-ICP-MS & $\begin{array}{c}\text { ID } \\
\text { Sample digestion }\end{array}$ & $7.42 \mathrm{mg} \mathrm{kg}^{-1}$ & $0.7 \mathrm{mg} \mathrm{kg}^{-1}$ & 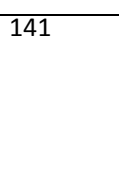 \\
\hline & ICP-MS/MS & $\begin{array}{c}\text { ID } \\
\text { Dilution (Ethanol) }\end{array}$ & $\begin{array}{c}0.5-2.0 \mu \mathrm{g} \\
\mathrm{kg}^{-1}\end{array}$ & $7.231 \mu \mathrm{g} \mathrm{g}^{-1}$ & 142 \\
\hline $\mathrm{Sb}$ & ICP-MS & EC (Kerosene,1:3) & $\begin{array}{c}0.0395 \mu \mathrm{g} \\
\mathrm{kg}^{-1}\end{array}$ & $\begin{array}{c}0.0528- \\
0.399 \mu \mathrm{g} \mathrm{kg}^{-1}\end{array}$ & 50 \\
\hline $\mathrm{Si}$ & ICP-OES & $\begin{array}{c}\text { EC (Aqueous } \\
\text { standards) } \\
\text { Emulsification } \\
\text { IS: Y }\end{array}$ & $\begin{array}{c}0.024 \mathrm{mg} \\
\mathrm{kg}^{-1}\end{array}$ & $\begin{array}{c}0.34-0.40 \\
\mathrm{mg} \mathrm{kg}^{-1}\end{array}$ & 125 \\
\hline & ICP-MS & EC (Kerosene,1:3) & $7.44 \mu \mathrm{g} \mathrm{kg}^{-1}$ & $\begin{array}{c}6.02-8220 \\
\mu g k^{-1}\end{array}$ & 50 \\
\hline & ICP-OES & EC & $\begin{array}{c}\text { Room } \\
\text { temperatur } \\
\text { e (Spray } \\
\text { chamber): } \\
3-26 \mu^{\circ g^{-1}} \\
200 \text { oC } \\
\text { (Spray }\end{array}$ & n.d. & 132 \\
\hline
\end{tabular}




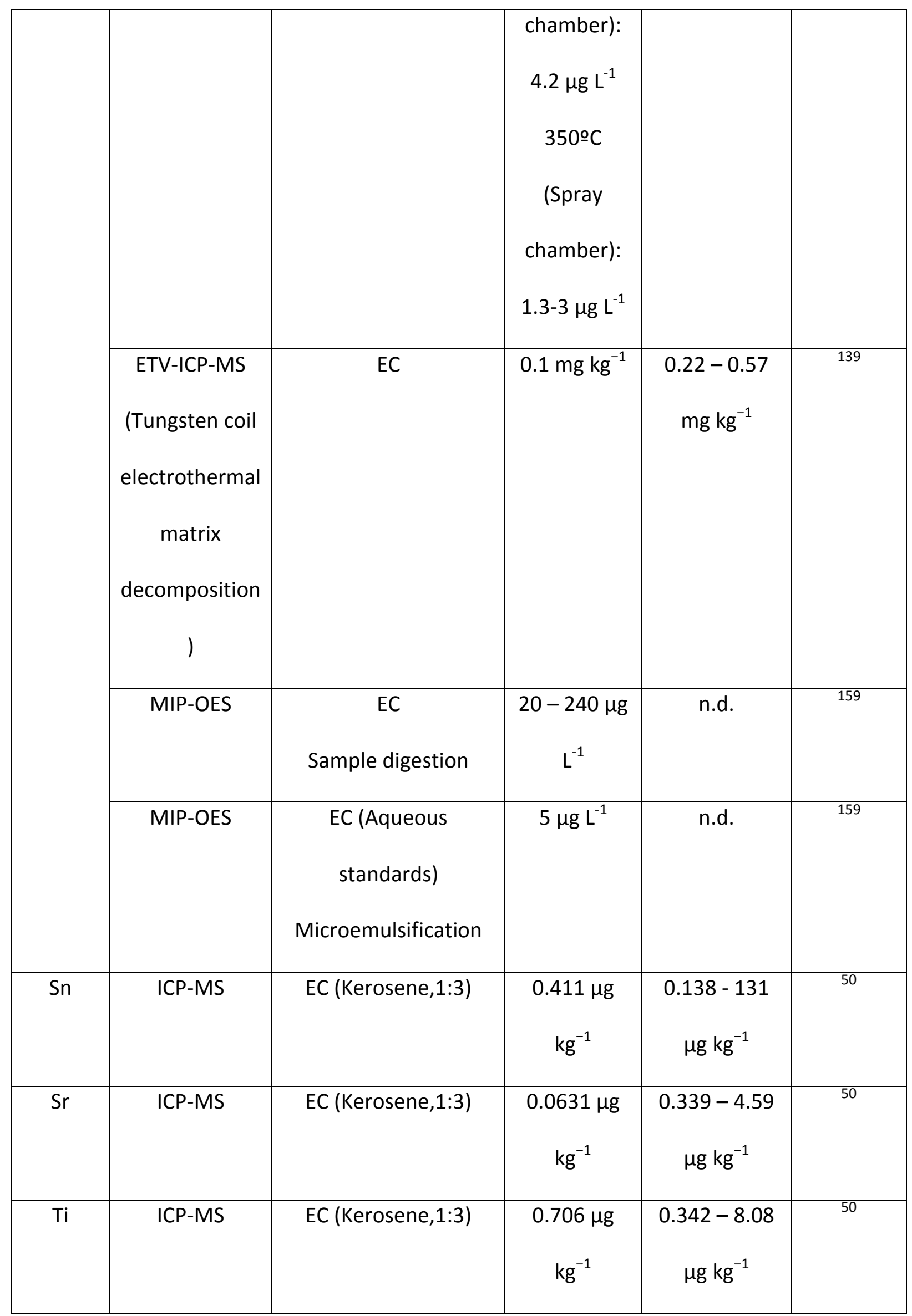




\begin{tabular}{|c|c|c|c|c|c|}
\hline & ICP-MS & $\begin{array}{c}\text { EC (Aqueous } \\
\text { standards) } \\
\text { Microemulsification }\end{array}$ & $12.8 \mu \mathrm{g} \mathrm{L}^{-1}$ & $\begin{array}{c}145.8-180 \\
\mu g L^{-1}\end{array}$ & 111 \\
\hline \multirow[t]{4}{*}{ V } & ICP-MS & EC (Kerosene,1:3) & $\begin{array}{c}0.0409 \mu \mathrm{g} \\
\mathrm{kg}^{-1}\end{array}$ & $\begin{array}{c}0.186-1.36 \\
\mu g \mathrm{~kg}^{-1}\end{array}$ & 50 \\
\hline & ICP-MS & EC & $\begin{array}{c}\text { Room } \\
\text { temperatur } \\
\text { e (Spray } \\
\text { chamber): } \\
0.17 \mathrm{ng} \mathrm{mL}^{-1} \\
110^{\circ} \mathrm{C} \\
\text { (Spray } \\
\text { chamber): } \\
0.06 \mathrm{ng} \mathrm{mL}^{-1} \\
200 \circ \mathrm{C} \\
\text { (Spray } \\
\text { chamber): } \\
0.08 \mathrm{ng} \mathrm{mL}^{-1}\end{array}$ & $\begin{array}{c}1.30-1.40 \\
\mu g L^{-1}\end{array}$ & 133 \\
\hline & $\begin{array}{l}\text { ETV-ICP-MS } \\
\text { (Pd as } \\
\text { modifier) }\end{array}$ & EC & $1 \mathrm{ng} \mathrm{g}^{-1}$ & n.d. & 93 \\
\hline & WCAES & $\begin{array}{c}\text { Tungsten coil } \\
\text { atomizer }\end{array}$ & $\begin{array}{c}90-500 \mu g \\
\mathrm{~kg}^{-1}\end{array}$ & n.d. & 170 \\
\hline
\end{tabular}




\begin{tabular}{|c|c|c|c|c|c|}
\hline & & Standard addition & & & \\
\hline W & ICP-MS & EC (Kerosene,1:3) & $\begin{array}{c}0.0177 \mu g \\
\mathrm{~kg}^{-1}\end{array}$ & $\begin{array}{c}0.0181- \\
0.121 \mu \mathrm{gg}^{-1}\end{array}$ & 50 \\
\hline \multirow[t]{7}{*}{$\mathrm{Zn}$} & ICP-OES & EC (Kerosene, 1:10) & $\begin{array}{c}0.011 \mathrm{mg} \\
\mathrm{kg}^{-1}\end{array}$ & $\begin{array}{c}0.099-2.4 \\
\mathrm{mg} \mathrm{kg}^{-1}\end{array}$ & 114 \\
\hline & ICP-OES & $\begin{array}{c}\text { EC (Ethanol, 1:10 for } \\
\text { vegetable oil and 1:20 } \\
\text { biodiesel) } \\
\text { IS: Y }\end{array}$ & $0.08 \mu \mathrm{g} \mathrm{g}^{-1}$ & $\begin{array}{c}1.0-9.1 \mu g \\
g^{-1}\end{array}$ & 5 \\
\hline & ICP-OES & $\begin{array}{l}\text { EC (1-Propanol, 1:10 } \\
\text { for vegetable oil and } \\
\text { 1:20 biodiesel) } \\
\qquad \text { IS: Y }\end{array}$ & $0.05 \mu \mathrm{g} \mathrm{g}^{-1}$ & $\begin{array}{c}1.0-9.1 \mu g \\
g^{-1}\end{array}$ & 5 \\
\hline & ICP-MS & EC (Kerosene,1:3) & $\begin{array}{c}0.211 \mu \mathrm{g} \\
\mathrm{kg}^{-1}\end{array}$ & $\begin{array}{c}2.8-27.4 \mu g \\
\mathrm{~kg}^{-1}\end{array}$ & 50 \\
\hline & ICP-MS & $\begin{array}{c}\text { EC (Aqueous } \\
\text { standards) } \\
\text { Microemulsification }\end{array}$ & $\begin{array}{c}4.22-4.25 \\
\mu g \mathrm{~L}^{-1}\end{array}$ & $\begin{array}{c}64.7-184.3 \\
\mu g L^{-1}\end{array}$ & 111 \\
\hline & FAAS & $\begin{array}{c}\text { EC } \\
\text { Microemulsification }\end{array}$ & $0.08 \mathrm{mg} \mathrm{L}^{-1}$ & $\begin{array}{c}0.49-0.68 \\
\mathrm{mg} \mathrm{L}^{-1}\end{array}$ & 149 \\
\hline & $\begin{array}{l}\text { Anodic } \\
\text { stripping } \\
\text { voltammetry }\end{array}$ & $\begin{array}{l}\text { Bismuth film } \\
\text { electrode } \\
\text { Sample digestion }\end{array}$ & $18 \mathrm{ng} \mathrm{L}^{-1}$ & $\begin{array}{c}2.3-4.0 \mathrm{mg} \\
\mathrm{kg}^{-1}\end{array}$ & 166 \\
\hline
\end{tabular}




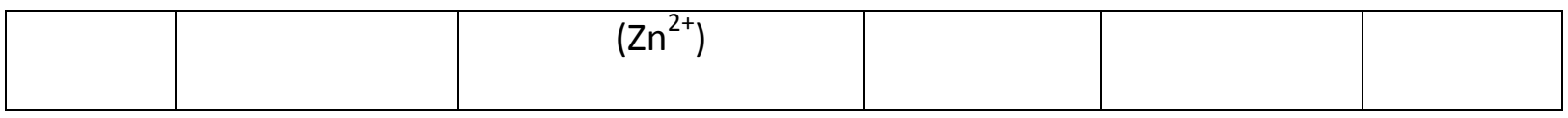

n.d.: non determined in real samples

\subsection{Comparison among techniques}

As it has been discussed throughout the previous sections, different approaches have been developed for the determination of trace elements in biodiesel samples. Because metal concentration in biodiesel samples (Table 3) is usually low, the selection of the determination technique could be considered as one of the most challenging steps. ${ }^{105}$ Table 4 gives a list of the analytical techniques used to carry out biodiesel analysis together with the frequency of use (percentage). The included data have been calculated taken in account the data shown in the Table 3. Three columns have been included: $(i)$ the first one gives an overview of the overall situation; (ii) the second one summarizes the data found for those elements considered by the existing legislation $(\mathrm{Ca}, \mathrm{K}, \mathrm{Mg}, \mathrm{Na}, \mathrm{P}$ and $\mathrm{S}),{ }^{124,102}$ and, (iii) the last one shows the data for the remaining elements. It may be observed that ICP-OES and ICP-MS have been the most frequently applied (Table 4). ${ }^{4,50,90-93,104-111}$ The main advantages of those techniques over AAS are that they allow simultaneous determination of several analytes and they provide a wide dynamic range. ${ }^{172}$ Furthermore, limits of detection are low enough to perform the trace elements determination. ${ }^{173}$

Table 4. Summary of the percentage of application of each technique discussed throughout the document for the analysis of biodiesel samples.

\begin{tabular}{|c|c|c|c|}
\hline & $\begin{array}{c}\text { All the detected } \\
\text { elements (\%) }\end{array}$ & Elements (\%) & Elements (\%) \\
\hline ICP-OES & 39 & 51 & 30 \\
\hline
\end{tabular}




\begin{tabular}{|c|c|c|c|}
\hline ICP-MS & 26 & 6 & 39 \\
\hline FAAS & 11 & 19 & 6 \\
\hline ETAAS & 7 & 2 & 6 \\
\hline Voltammetry & 5 & 4 & 2 \\
\hline CE & 4 & 8 & 1 \\
\hline IC & 3 & 5 & 3 \\
\hline WCAES & 2 & 2 & 2 \\
\hline FAES & 2 & 4 & 2 \\
\hline MIP-OES & 1 & & 1 \\
\hline FI-CV-AAS & 1 & & \\
\hline
\end{tabular}

Standards describing the requirements for FAME ${ }^{101,102}$ establish the contents of $\mathrm{Na}, \mathrm{K}$, $\mathrm{Mg}, \mathrm{Ca}, \mathrm{P}$ and $\mathrm{S}$ at the $\mathrm{mg} \mathrm{kg}^{-1}$ level. Because ICP techniques are more sensitive to the presence of organic compounds, AAS have been proposed as alternative techniques for the determination of these elements. By comparing the second and the third column of the table, it can be observed that within this frame, $19 \%$ of the analytical methodologies were developed for FAAS. Moreover, it is important to note that ICP-MS has been marginally applied for 'major' elements, whereas for trace elements it is the most employed technique. Figure 4 compares the situation found for 5 different elements. These data have been obtained from data collected in Table 3. The data of Y-axis have been obtained according to:

Freq. use technique $A(\%)=\frac{\text { studies by technique } A \text { for element } X}{\sum \text { studies by all the techniques for element } X} \times 100$ Equation 1

As Figure 4 shows, ICP-OES and ICP-MS are the most employed techniques in the researches related with biodiesel analysis. Some studies dialing with FAAS determinations 
also appeared. Spectral interferences for AAS are minimized compared with other techniques, whereas sample throughput and limits of detection are favourable for ICP techniques. This figure algo shows the total number of studies related with the determination of each one of the elements considered. As expected, the most studied ones are $\mathrm{Na}, \mathrm{K}, \mathrm{Ca}, \mathrm{Mg}, \mathrm{P}$ and $\mathrm{Cu}$.

Chromatographic techniques have been developed for the determination of the alkaline elements. However, because LODs are slightly higher than those found with spectrometric techniques they have been mainly used for the determination of alkalines. $\mathrm{Cu}, \mathrm{Fe}, \mathrm{Mn}$ and $\mathrm{Zn}$ are expected to be found at sub-mg kg${ }^{-1}$ or even $\mu \mathrm{g} \mathrm{kg}^{-1}$ level, for that reason, ICP techniques have been extensively applied. It is important to note that since $\mathrm{Cu}$ and $\mathrm{Zn}$ are redox active, voltammetry has been proposed as alternative.

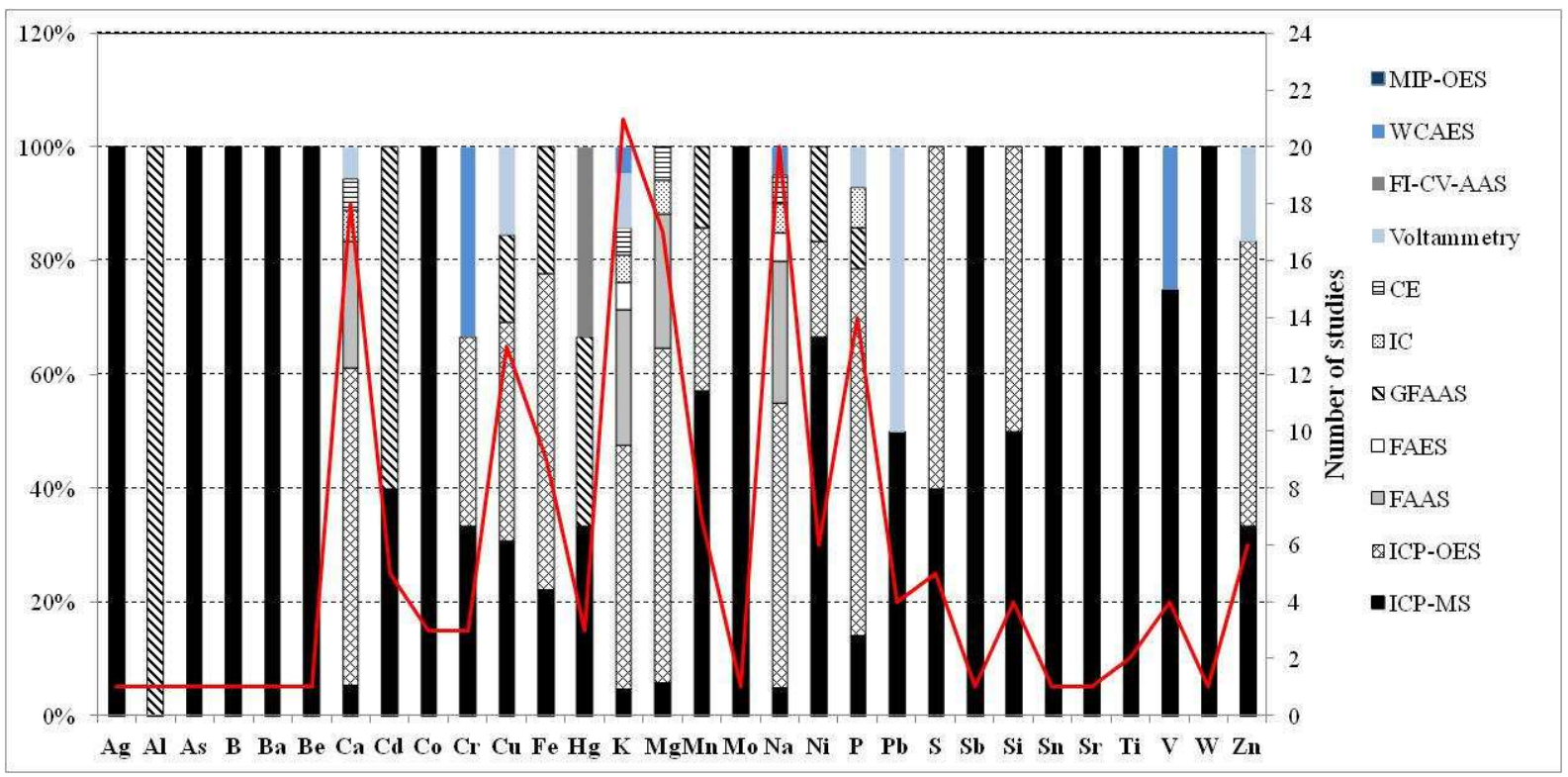

Figure 4. Techniques employed for the determination of several metals in biodiesel samples (bars) and number of studies dealing with the determination of each one of the elements (red line).

Table 5 summarizes the Standards dealing with the elemental determination in biodiesel samples. This table also includes the analytical techniques recommended by each 
one of those Standards. If this information is compared with that included in Figure 4 it may be concluded that ICP-MS is not yet considered. This is likely due to the fact that the elements determined by the Standards are the most abundant in biodiesel samples $(\mathrm{Na}, \mathrm{K}, \mathrm{Ca}$ and $\mathrm{Mg}$ ) at levels that fit perfectly with the LODs afforded by techniques such as FAAS or ICP-OES. Because sulfur determination through ICP-OES and ICP-MS presents some problems due to volatility effect, XRF techniques are often recommended by the corresponding Standards.

Table 5. List of standards for the elemental determination of biodiesel samples.

\begin{tabular}{|c|c|c|c|}
\hline Standard reference & Standard title & $\begin{array}{l}\text { Determined } \\
\text { elements }\end{array}$ & Analytical technique \\
\hline ASTM D7039 & $\begin{array}{l}\text { Standard Test Method } \\
\text { for Sulfur in Gasoline, } \\
\text { Diesel Fuel, Jet Fuel, } \\
\text { Kerosine, Biodiesel, } \\
\text { Biodiesel Blends, and } \\
\text { Gasoline-Ethanol } \\
\text { Blends by } \\
\text { Monochromatic } \\
\text { Wavelength Dispersive } \\
\text { X-ray Fluorescence } \\
\text { Spectrometry }\end{array}$ & $\mathrm{S}$ & MWDXRF \\
\hline EN 14107 & $\begin{array}{l}\text { Fat and oil derivatives } \\
\text { - Fatty Acid Methyl } \\
\text { Esters (FAME) - }\end{array}$ & $\mathrm{P}$ & ICP-OES \\
\hline
\end{tabular}




\begin{tabular}{|c|c|c|c|}
\hline & $\begin{array}{l}\text { Determination of } \\
\text { phosphorus content by } \\
\text { inductively coupled } \\
\text { plasma (ICP) emission } \\
\text { spectrometry }\end{array}$ & & \\
\hline EN 14108 & $\begin{array}{l}\text { Fat and oil derivatives } \\
\text { - Fatty Acid Methyl } \\
\text { Esters (FAME) - } \\
\text { Determination of } \\
\text { sodium content by } \\
\text { atomic absorption } \\
\text { spectrometry }\end{array}$ & $\mathrm{Na}$ & FAAS \\
\hline EN 14109 & $\begin{array}{l}\text { Fat and oil derivatives } \\
\text { - Fatty Acid Methyl } \\
\text { Esters (FAME) - } \\
\text { Determination of } \\
\text { potassium content by } \\
\text { atomic absorption } \\
\text { spectrometry }\end{array}$ & K & FAAS \\
\hline EN 14538 & $\begin{array}{l}\text { Fat and oil derivatives } \\
\text { - Fatty acid methyl } \\
\text { ester (FAME) - } \\
\text { Determination of } \mathrm{Ca} \text {, } \\
\mathrm{K}, \mathrm{Mg} \text { and } \mathrm{Na} \text { content } \\
\text { by optical emission }\end{array}$ & $\mathrm{Ca}, \mathrm{Mg}, \mathrm{Na}, \mathrm{K}$ & ICP-OES \\
\hline
\end{tabular}




\begin{tabular}{|c|c|c|c|}
\hline & $\begin{array}{l}\text { spectral analysis with } \\
\text { inductively coupled } \\
\text { plasma (ICP OES) }\end{array}$ & & \\
\hline ASTM D6751 & $\begin{array}{l}\text { Standard Specification } \\
\text { for Biodiesel Fuel } \\
\text { Blend Stock (B100) for } \\
\text { Middle Distillate Fuels }\end{array}$ & \multicolumn{2}{|l|}{ Specifications* } \\
\hline ASTM D7467 & $\begin{array}{l}\text { Standard Specification } \\
\text { for Diesel Fuel Oil, } \\
\text { Biodiesel Blend (B6 to } \\
\text { B20) }\end{array}$ & \multicolumn{2}{|l|}{ Specifications* } \\
\hline prEN16709 & $\begin{array}{l}\text { Automotive fuels - } \\
\text { High FAME diesel fuel } \\
\text { (B20 or B30) - } \\
\text { Requirements and test } \\
\text { methods }\end{array}$ & \multicolumn{2}{|l|}{ Specifications* } \\
\hline \multicolumn{4}{|c|}{ *These standards refer to : } \\
\hline \multicolumn{2}{|c|}{ ASTM D4294 (S by EDXRF) } & $\mathrm{S}$ & EDXRF \\
\hline \multicolumn{2}{|c|}{ ASTM D2622 (S by WDXRF) } & $S$ & WDXRF \\
\hline \multicolumn{2}{|c|}{ ASTM D7039 (S by MWDXRF) } & $\mathrm{S}$ & MWDXRF \\
\hline \multicolumn{2}{|c|}{ ASTM D4951 (P by ICP-OES) } & $\mathrm{P}$ & ICP-OES \\
\hline \multicolumn{2}{|c|}{ EN 14538 (Ca, Mg, K and Na by ICP-OES) } & $\mathrm{Ca}, \mathrm{Mg}, \mathrm{Na}, \mathrm{K}$ & ICP-OES \\
\hline
\end{tabular}

\section{Bioethanol}


Bioethanol is refered to as ethanol obtained through carbohydrates fermentation from a wide renewable feedstock (e.g. sugar cane, corn and switchgrass) using various types of microorganisms. ${ }^{1,174}$

Bioethanol can be employed directly or mixed in several concentrations with unlead gasoline (e.g. E85 ethanol fuel is a mixture of $85 \%$ of bioethanol and $15 \%$ of gasoline). ${ }^{174}$ This kind of mixture bioethanol-gasoline is known as fuel ethanol. Modifications in the engine are not required up to E10, whereas higher concentrations of ethanol are appropriate for flex-fuel engines. ${ }^{174}$

Bioethanol and fuel ethanol show several advantages against fosil fuels as: (i) A reduction of greenhouse emissions down to $65 \%$ lower than petrol; ${ }^{174,175}$ (ii) ethanol is an oxygenated additive which improves the octane rating of fuels; and, (iii) burning is clean and therefore toxicity of the generated compounds is low. ${ }^{174}$ For these reasons the production of fuel ethanol and bioethanol is growing with the simultaneous increase in the research related with the production and characterization of these new fuels. The research in fuel ethanol production and characteritzation was developed in the 70s whereas the production of research documents dealing with bioethanol virtually started at the beginnig of the XXI century. In both cases the number of papers per year has exponentially increased along the last 15 years up to more than 1000 research documents a year.

\subsection{Synthesis and presence of metals. Importance of their determination.}

Several materials have been employed to produce bioethanol. ${ }^{175-177}$ Synthesis process depends strongly on the raw material. First generation bioethanol is produced from foodstuffs such as beet, sugarcane, cereal grain or corn, among others. ${ }^{1}$ Meanwhile, second generation 
bioethanol generates from wood or straw and it is also known as "lignocellulosic bioethanol".1,175

The production of bioethanol includes four main steps (Figure 5): (i) physico-chemical structure break up of the raw material; (ii) enzymatic hydrolisis of cellulose to monomeric sugars; (iii) conversion of these sugars to ethanol by fermentation; (iv) separation of ethanol from the fermentation broth by distilation generally followed by a final dehydratation. ${ }^{175}$

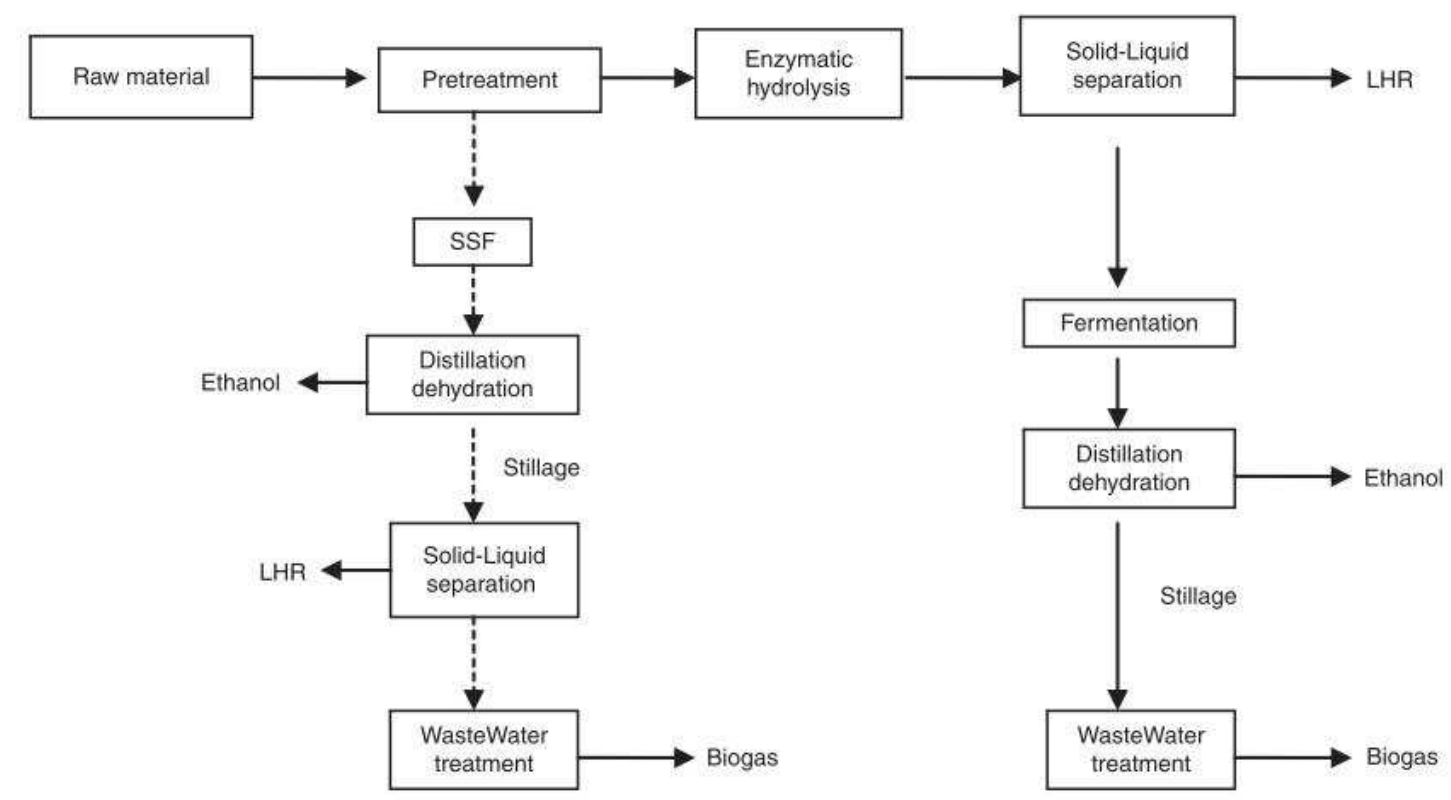

Figure 5. General flow chart of bioethanol production process from lignocelulosic biomass (second generation). SSF: Simultaneous Saccharification and Fermentation; LHR: solid Lignin Hydrolysate Residue. Taken from ${ }^{175}$.

At the end of the proccess either anhydrous ethanol (content of water lower than $0.7 \%$ ) or hydrated ethanol (content of water from 2 to $7 \%$ ) can be obtained. ${ }^{178}$ The final product also may contain up to roughly 300 compounds depending on the origin of the raw material and the applied treatment. ${ }^{1}$ Compounds such as alcohols (methanol, 1-propanol, isopropanol, 1butanol, 2-butanol, etc), esters (ethyl formate, ethyl acetate, etc), ketones, aldehydes can be present. For this reason, bioethanol matrix can vary. This fact together with the low metals content can hinder their quantification in bioethanol or fuel ethanol samples. 
It is difficult to establish the source of metals in bioethanol. The first one can be the raw material. ${ }^{2,179-181}$ Thus the metal content depends on the soil where raw material has grown as well as on the atmospheric pollution. ${ }^{181}$ Concentrations on the order of $\mathrm{mg} \mathrm{kg}^{-1}$ have been found in biomass for 26 elements ( $\mathrm{Sr}, \mathrm{Ba}, \mathrm{F}, \mathrm{Cl}, \mathrm{Ti}, \mathrm{V}, \mathrm{Cr}, \mathrm{Mn}, \mathrm{Fe}, \mathrm{Co}, \mathrm{Ni}, \mathrm{Cu}, \mathrm{Mo}, \mathrm{Zn}, \mathrm{Cd}$, $\mathrm{Hg}, \mathrm{Al}, \mathrm{Sn}, \mathrm{Pb}, \mathrm{B}, \mathrm{As}, \mathrm{Sb}, \mathrm{S}, \mathrm{Se}, \mathrm{Te}$ and P). Meanwhile, the content of others ( $\mathrm{Na}, \mathrm{K}, \mathrm{Ca}, \mathrm{Mg}$ and $\mathrm{Si}$ ) in products frequently used to obtain bioethanol can be as high as $\mathrm{g} \mathrm{kg}^{-1}$. Moreover, bioethanol may be contaminated with metals during its synthesis. ${ }^{179,180,182}$ Several metals can also appear during the fuel storage and transport in metallic containers. ${ }^{179-183}$ Finally, some metallic species can be added as additives to promote the combustion process. ${ }^{184}$ Obviously, when a blend is considered (e.g., ethanol fuel) metals and metalloids come mainly from gasoline. $^{120}$

As it has been previously mentioned, metals and other trace elements are present at very low concentrations in bioethanol and fuel ethanol. However, their determination is important for several reasons: (i) they can cause catalyst deactivation in the bioethanol transformation process ${ }^{1}$ (e.g. sulfur impurities) and in industrial process; ${ }^{179,181}$ (ii) some metals such as $\mathrm{As}, \mathrm{Cd}, \mathrm{Hg}, \mathrm{Tl}$ or $\mathrm{Pb}$ cause health problems even at low concentrations; ${ }^{181,185}$ (iii) others, $\mathrm{Fe}$ and $\mathrm{Cu}$, cause damage of the vehicle engine; ${ }^{179,181,182,186-189}$ (iv) heavy metals present an environmental risk: ${ }^{182,184,189,190}$ and, $(v)$ some elements preclude the stability of the bioethanol or fuel ethanol (e.g. $\mathrm{Cu}$ can catalyze the oxidation of gasoline in presence of alcohol). ${ }^{181,182,187,191}$

In Brazil, where bioethanol and ethanol fuel are widely used, the quality of fuel ethanol is carefully regulated by the National Agency of Petroleum (ANP). ${ }^{182,183,187,188}$ However, only a standard for sulfur and copper (D4806-07a; ${ }^{176}$ D3237 ${ }^{181}$ ) and another for iron (D1688-07 ${ }^{188}$ ) have been establish by ASTM. Besides, International Organizacion for Standarization (ISO) is expected to publish a standard for $\mathrm{Cu}, \mathrm{P}$ and $\mathrm{S}$ in the near future. ${ }^{176}$ 
The most employed techniques to quantify metals in biofuel products are ICP-OES, ICP-MS, electrothermal atomic absorption spectroscopy (ETAAS) and FAAS.

\subsection{Analysis by ICP techniques}

\subsubsection{Conventional sample introduction systems and electrothermal vaporization}

Several authors have reported non-spectral interferences when ethanol or other alcohols are analyzed by ICP techniques. Thus, an enhancement in the signal is observed for ethanol as compared to water. $^{10,14,22,23,31,42,188,190,192}$ For example, McCrindle et al. ${ }^{22}$ reported such a change in ICP-OES sensitivity for $\mathrm{Cd}$ and $\mathrm{Fe}$. In the case of $\mathrm{Fe}$ this fact caused an improvement in limits of detection (LOD) however for $\mathrm{Cd}$ the limit of detection was better for pure water.

In other study developed by the same authors the LODs, sensitivity and the background equivalent concentration (BEC) were determined for $\mathrm{Pb}, \mathrm{Cd}, \mathrm{Al}, \mathrm{Cr}, \mathrm{Fe}, \mathrm{Na}, \mathrm{Mn}$, Mo and $\mathrm{V}$ in presence and in absence of ethanol. They observed that the operating conditions played a very important role. For a $0.6 \mathrm{~L} \mathrm{~min}^{-1}$ nebulizer gas flow rate and $1.36 \mathrm{~kW} \mathrm{RF}$ power, the sensitivity for all analytes increased with ethanol concentration by a factor that depended on the element. In contrast, for a $0.4 \mathrm{~L} \mathrm{~min}^{-1}$ flow rate the addition of ethanol did not improve the sensitivity for almost all the analytes and it decreased for some elements such as $\mathrm{Na}$ and $\mathrm{Al}^{23}$

On the other hand, some authors reported that the presence of ethanol into the plasma caused an increase in the background signal. ${ }^{20,21,23}$ According to McCrindle et al. ${ }^{14,23}$ the improvement in terms of sensitivity was similar to that in terms of background intensity. ${ }^{23}$ The same effect was observed for $95 \%$ ethanol solutions, the LOD were similar to pure water 
although the sensitivity for $95 \%$ ethanol solution was between 2 and 5 times higher than for water. $^{14}$

Saint ${ }^{\text {Pierre }}$ et $a l .{ }^{190}$ reported that in ICP-MS the signal in presence of ethanol was from 15 to 25 times higher than the signal for plain water solutions depending on the isotope. These findings were in concordance with the results obtained by Dressler et ll $^{42}$ who evaluated the effect of methanol, ethanol and isopropanol. On the other hand, Rocha et al. ${ }^{188}$ reported that for some elements $7 \%$ of water in hydrated fuel ethanol (HFE) induced a 30\% signal decrease with respect to anhydrous fuel ethanol (AFE). However, the opposite effect was observed when ethanol was added to a xylene solution. ${ }^{14,22}$ In fact, the addition of ethanol to pure xylene yielded a decrease in the hydrogen line intensity caused by a concomitant decrease in the plasma temperature. ${ }^{14}$

In order to overcome non spectral interferences caused by ethanol, several methods have been developed among them: (i) sample dilution; (ii) matrix matching; (iii) internal standardization; and, (iv) isotope dilution method, in ICP-MS. Besides, alternative sample introduction systems have been characterized from the point of view of matrix effects.

Several studies recommend ethanol or fuel ethanol dilution with an appropriate solvent. ${ }^{38,39,190,193}$ For this kind of samples, water is the most widely employed, $38,39,190,193$ although other solvents can be employed to dilute these type of samples. ${ }^{38}$ The choice of the solvent may affect the method sensitivity, precision and accuracy. Thus, using a programmable temperature spray chamber, it has been verified that the sensitivity in isopropanol is from three to four times higher than that in methanol. ${ }^{194}$ However, an obvious limitation of sample dilution is that LODs and sensitivities are severely degraded.

As regards matrix matching Rocha et al. ${ }^{188}$ prepared the standards in ethanol with $0.5 \%$ of water to analyze AFE and ethanol with $7 \%$ of water to analyze HFE. They did not find significant differences between found concentrations by matrix matching in ICP-OES 
and isotope dilution in ICP-MS. Additional studies have tried to minimize non spectral interferences in the analysis of metals in bioethanol and fuel ethanol through matrix matching. ${ }^{39,184,185,188,193}$ Unfortunately, this method is time consuming and inaccurate in many cases because normally the matrix of the sample is very complex and/or unknown. On the other hand, matrix matching is not appropriate for ethanol and ethanol fuel analysis by ICPMS because carbon deposits are formed in sampler and skimmer. ${ }^{39}$

On the other hand, internal standard calibration can be applied in order to carry out an accurate and precise analysis in ethanol and ethanol fuel. ${ }^{188,193}$ This methodology shows, as the most important concern the correct selection of the best internal standard. Tormen et al. ${ }^{190}$ evaluated ytrium, rhodium and iridium as internal standards to analyze 19 elements by ICPMS. External calibration was taken as reference. The authors concluded that ytrium or even rhodium could be satisfactorily employed as an IS in the routine analysis of fuel ethanol. However, provided that the samples were diluted the found concentrations for $\mathrm{V}, \mathrm{Ni}, \mathrm{Ga}, \mathrm{Sr}$, $\mathrm{Cd}, \mathrm{Sn}$ and $\mathrm{Tl}$ were below the limit of quantification. ${ }^{190}$

Isotope dilution, in turn, has been applied in order to minimize or remove non-spectral interferences in ICP-MS with good results. ${ }^{39,185,190}$ This method shows several advantages against internal standard calibration because it is very simple, fast and clean. ${ }^{185}$

In order to solve some of the matrix effects, alternative sample introduction systems have been employed: (i) electrothermal vaporization; (ii) desolvation systems; (iii) cooled spray chamber; and, (iv) specific nebulizers.

Electrothermal vaporization (ETV) is a good approach to remove non spectral interferences when ethanol and fuel ethanol are analyzed. ${ }^{184,185,195}$ Nonetheless, few authors have reported methods to carry out the determination of some elements in this kind of samples through ETV coupled to ICP-MS. ${ }^{184,185}$ Saint ${ }^{`}$ Pierre et al. ${ }^{185}$ reported a method to determine trace metals in alcohol fuel by Isotopic Dilution ETV- ICP/MS. In this study $\mathrm{Ag}, \mathrm{Cd}, \mathrm{Cu}, \mathrm{Pb}$ 
and $\mathrm{Tl}$ were determined fuel alcohol with $\mathrm{LOD}$ of $0.02,0.08,0.1,0.05,0.001 \mu \mathrm{g} \mathrm{L}^{-1}$, respectively (Table 6). For $\mathrm{Cd}, \mathrm{Pb}$ and $\mathrm{Tl}$ that evaporated at lower temperatures, the use of $\mathrm{Pd}$ aqueous solution as chemical modifier was necessary. However, in the $\mathrm{Ag}$ and $\mathrm{Cu}$ determination it was not necessary to use chemical modifiers because these elements showed lower volatilities than $\mathrm{Cd}, \mathrm{Pb}$ and $\mathrm{Tl}^{185}$ In another study, the determination of $\mathrm{Ag}, \mathrm{As}, \mathrm{Cd}$, $\mathrm{Cu}, \mathrm{Co}, \mathrm{Fe}, \mathrm{Mn}, \mathrm{Ni}, \mathrm{Sb}, \mathrm{Sn}$, and $\mathrm{Tl}$ in ethanol fuel was successfully done through ETV-ICPMS using external calibration with ethanolic solutions and $\mathrm{Pd}$ as chemical modifier. ${ }^{184}$ Recoveries for all elements were between 80 and $120 \%$ without modifier and from 60 to $140 \%$ with palladium.

The spray chamber can be cooled in order to minimize the mass of organic material reaching the plasma. ${ }^{176,177}$ Thus, for instance, a cyclonic spray chamber was operated at $10^{\circ} \mathrm{C}$ with the aim of determining $\mathrm{Cu}, \mathrm{P}$ and $\mathrm{S}$ in ethanol through ICP-OES with recoveries between 93.5 and $107.3 \% .{ }^{176}$ Other alternative approach is a spray chamber cooled by a Peltier effect based system making it possible to introduce pure ethanol into the plasma.

Desolvation systems are based on a previous aerosol heating step followed by either a membrane or a condenser. The first stage promotes the efficient solvent evaporation from the aerosol whereas the second one removes the generated vapor. This device is also appropriate to overcome matrix effects. Alcohols have been analyzed through ICP-OES with membrane desolvator ${ }^{196}$ or cryogenic desolvation. ${ }^{197}$ Rocha et al. ${ }^{188}$ reported a method allowing the determination of $\mathrm{Cu}$ and $\mathrm{Fe}$ in AFE and HFE through ICP-OES by direct sample introduction using an ultrasonic nebulizer and membrane desolvator (USN-MD-ICP-OES) and they obtained similar LODs as those previously reached in ICP-MS by other authors. ${ }^{39,185,190}$ External calibration was applied together with matrix matching using standards containing around $0.4 \%$ of water for AFE and $7 \%$ of water for HFE. The found concentrations were compared with ID-ICP-MS technique obtaining concordant values between these two 
approaches. ${ }^{188}$ Saint ${ }^{\text {Pierre }}$ et $a l .{ }^{39}$ reported a study using a flow injection system coupled to an ultrasonic nebulizer and desolvator to carry out the analysis of AFE and HFE in ICP-MS. The obtained LODs for $\mathrm{Ag}, \mathrm{Cd}, \mathrm{Co}, \mathrm{Cu}, \mathrm{Fe}, \mathrm{Mn}, \mathrm{Ni}$ and $\mathrm{Pb}$ were higher than those found by ETV-ICP-MS. ${ }^{39,184}$

Additional systems employed for bioethanol and ethanol fuel samples analysis include low sample consumption systems. A microconcentric nebulizer (MCN) was used by Tormen et al. ${ }^{190}$ to carry out the determination of $\mathrm{Cu}, \mathrm{Cd}, \mathrm{Ni}, \mathrm{Pb}, \mathrm{Tl}$ and $\mathrm{Sn}$ in fuel ethanol through ICP-MS. Compared with conventional nebulizers, MCN showed lower limits of detection and better precision even at lower sample consumption rates. This was due to the finer primary aerosols and higher analyte transport efficiencies as compared to conventional nebulization systems. ${ }^{198}$ External calibration and internal standardization were applied and the results were in concordance with those found with isotopic dilution. ${ }^{190}$ With this device it was possible to introduce in the plasma $70 \%$ ethanol solutions. For higher ethanol concentrations carbon deposits appeared in the ICP-MS interface cones. ${ }^{190}$

Spectral interferences in ICP techniques when organic samples (e.g. ethanol) have been extensively described by several authors. ${ }^{120,199}$ In ICP-OES these interferences are related with peak overlapping. ${ }^{200}$ Polyatomic interferences occur in ICP-MS when ethanol is injected into the plasma. For example, the formation of ${ }^{12} \mathrm{C}_{2}{ }^{+},{ }^{12} \mathrm{C}^{14} \mathrm{~N}^{+},{ }^{13} \mathrm{C}^{14} \mathrm{~N}^{+},{ }^{12} \mathrm{C}^{16} \mathrm{O}^{+}$, ${ }^{13} \mathrm{C}^{16} \mathrm{O}^{+},{ }^{12} \mathrm{C}^{17} \mathrm{O}^{+},{ }^{40} \mathrm{Ar}^{12} \mathrm{C}^{+},{ }^{40} \mathrm{Ar}^{13} \mathrm{C}^{+}$may interfere on ${ }^{24} \mathrm{Mg}^{+},{ }^{26} \mathrm{Mg}^{+},{ }^{27} \mathrm{Al}^{+},{ }^{28} \mathrm{Si}^{+},{ }^{29} \mathrm{Si}^{+},{ }^{52} \mathrm{Cr}^{+}$ and ${ }^{53} \mathrm{Cr}^{+}$determination, respectively. ${ }^{201}$ Recently, Neves et al. ${ }^{193}$ have tested several flow rates of oxygen in order to remove the carbon compounds formation. Solutions from 0 to $100 \%$ of ethanol at $\mathrm{O}_{2}$ flow rates between 0 and $262.5 \mathrm{~mL} \mathrm{~min}^{-1}$ were evaluated. These authors verified that flow-rates below $112.5 \mathrm{~mL} \mathrm{~min}^{-1}$ were insufficient to remove carbon compounds when ethanol concentration was higher than $80 \%$. On the other hand, an excess of oxygen in the plasma could caused the formation of metal oxide polyatomic species. ${ }^{111}$ 
Additional possibilities to remove spectral interferences due to polyatomic species in ICP-MS when ethanol and fuel ethanol is analyzed are the use of a dynamic collision cell (DCC), dynamic reaction cell (DRC) or collision-reaction interface (CRI). Kishi et al. ${ }^{202}$ reported a reduction of carbon-based interferences in alcohols using a DRC with pure ammonia as a reaction gas. Neves et al. ${ }^{193}$ evaluated the use of $\mathrm{He}$ or $\mathrm{H}_{2}$ as collision and reaction gases in a CRI system and they observed that the introduction of either two gases through the sampling cone was inefficient whereas opposite effect was observed when $\mathrm{H}_{2}$ was introduced through the skimmer cone. The signal at $\mathrm{m} / \mathrm{z}=56$ due to ${ }^{40} \mathrm{Ar}^{16} \mathrm{O}^{+}$was around 12fold lower when $60 \mathrm{~mL} \min ^{-1} \mathrm{H}_{2}$ or He were introduced through the skimmer cone in comparison with the signals without insertion of these gases. A similar behavior was observed for ${ }^{24} \mathrm{Mg}^{+}\left({ }^{12} \mathrm{C}_{2}{ }^{+}\right),{ }^{28} \mathrm{Si}^{+}\left({ }^{12} \mathrm{C}^{16} \mathrm{O}^{+}\right)$and ${ }^{52} \mathrm{Cr}^{+}\left({ }^{40} \mathrm{Ar}^{12} \mathrm{C}^{+}\right)$showing the capability of this device to reduce isobaric interferences when ethanol was analyzed. In the same study it was verified that reaction mode using $\mathrm{H}_{2}$ was more effective that collision mode with $\mathrm{He}$.

\subsection{Analysis by other techniques}

Although ICP based techniques have been the most widely used to carry out the determination of metals and metalloids in ethanol fuel, alternative methods have been explored such as ETAAS, ${ }^{179,203-208}$ FAAS, ${ }^{180,183,189,209-212}$ voltammetry, ${ }^{187,213,214}$ ionic chromatography (IC) ${ }^{182}$ or microwave plasma optical emission spectrometry (MIP-OES). ${ }^{181}$

Several modifiers have been used to carry out the determination of metals in bioethanol and ethanol fuel by ETAAS. The most used one corresponds to a mixture of $\mathrm{Pd}\left(\mathrm{NO}_{3}\right)_{2}$ and $\mathrm{Mg}\left(\mathrm{NO}_{3}\right)_{2}{ }^{203-205}$ although permanent modifiers as W-Rh mixture ${ }^{204}, \mathrm{Ru}-\mathrm{Zr}{ }^{206}$, Ir- $\mathrm{Rh}^{207}$ or W-Ir (co-injected) have also been evaluated. ${ }^{179}$ De Oliveira et al. ${ }^{203}$ carried out a comparative study of chemical modifiers employed to determine metals in alcohol fuel. Three 
possibilities were studied for six elements, $\mathrm{Pd}\left(\mathrm{NO}_{3}\right)_{2}+\mathrm{Mg}\left(\mathrm{NO}_{3}\right)_{2}$, W/Rh and $\mathrm{W}+$ coinjection of $\mathrm{Pd}\left(\mathrm{NO}_{3}\right)_{2}+\mathrm{Mg}\left(\mathrm{NO}_{3}\right)_{2}$. The last one was the modifier providing the best recoveries.

De Oliveira et al. ${ }^{204,205}$ developed two methods to carry out the determination of metals in fuel ethanol through ETAAS. In the first method they determined $\mathrm{Al}, \mathrm{As}, \mathrm{Cu}, \mathrm{Fe}$, $\mathrm{Mn}$ and $\mathrm{Ni}$ in ethanol fuel using a transversely heated graphite atomizer (THGA) and a $\mathrm{Pb}\left(\mathrm{NO}_{3}\right)_{2}$ and $\mathrm{Mg}\left(\mathrm{NO}_{3}\right)_{2}$ mixed modifier. The recoveries obtained went from 73 to $116 \%$ and the RSD for all elements was lower than $6 \% .^{205}$ In the second method they used W-Rh permanent modifier together with $\mathrm{Pd}\left(\mathrm{NO}_{3}\right)_{2}+\mathrm{Mg}\left(\mathrm{NO}_{3}\right)_{2}$. The values of RSD and LOD (Table 6) were similar to those achieved without permanent modifier and recoveries were between 81 and $109 \% .^{204}$

Saint Pierre et $a l{ }^{206}$ performed a study of several modifiers in order to propose the direct determination of $\mathrm{As}, \mathrm{Cu}, \mathrm{Fe}, \mathrm{Pb}, \mathrm{Sb}$ and $\mathrm{Sn}$ in alcohol fuel by ETAAS. Finally, they proposed to determine $\mathrm{Cu}$ and $\mathrm{Fe}$ without chemical modifier whereas $\mathrm{Ru}$ was selected as modifier to determine $\mathrm{As}, \mathrm{Sb}, \mathrm{Sn}$ and $\mathrm{Pb}$. In the case of $\mathrm{Pb}, \mathrm{NH}_{4} \mathrm{H}_{2} \mathrm{PO}_{4}$ could be employed as an alternative modifier. Recoveries were included within the 89.3 to $103.8 \%$ range. $^{206}$ Giacomelli et al. ${ }^{207}$ studied the use of Ir together with $\mathrm{Rh}$ as a permanent modifier to determine $\mathrm{As}, \mathrm{Cd}$ and $\mathrm{Pb}$ in pure ethanol by ETAAS. In this case, the obtained recoveries were between 94 and 96.7\%. Saint'Pierre et al. ${ }^{208}$ reported a method to determine $\mathrm{Cd}$ and $\mathrm{Pb}$ in fuel ethanol by ETAAS using a filter to eliminate the need for chemical modifications. The standards were prepared in ethanol and the recoveries ranged from 90 to $120 \%$.

Recently, Santos et al. ${ }^{179}$ have developed a method for simultaneous determination of $\mathrm{Cu}$ and $\mathrm{Pb}$ in ethanol fuel by ETAAS using a transversely heated graphite atomizer with $\mathrm{W}$ permanent modifier and co-injecton of Ir and they have analyzed 10 ethanol real fuel samples. 
Recovery was between 93 and $103 \%$ for $\mathrm{Cu}$ and from 96 to $110 \%$ for $\mathrm{Pb}$ while RSD was below $1 \%$ in all the cases.

Because FAAS provides rather high limits of detection (in the order of $\mathrm{mg} \mathrm{L}^{-1}$ ) the use of this technique to perform ethanol fuel analysis involves a previous preconcentration stage. ${ }^{180,183,189,210-212}$ Thus Alves et al. ${ }^{189}$ developed a method to determine Cd in ethanol fuel through FAAS using Moringa oleifera seeds as a on-line biosorbent to carry out the samples preconcentration. The recoveries for three samples were from 97.5 to $100 \%$ and LOD was $5.50 \mu \mathrm{g} \mathrm{L}^{-1}$. The same authors had developed a similar work using vermicompost as the adsorbent material and acceptable results in terms of precision and accuracy were obtained. ${ }^{212}$ Several authors have been reported on the determination of different metals through FAAS using modified silica gel as a preconcentration media. ${ }^{180,183,209-211}$ De Melo et al. ${ }^{210}$ employed a column with 5-amino-1,3,4-thiadiazole-2-thiol modified silica gel to preconcentrate Cd(II), $\mathrm{Co}(\mathrm{II}), \mathrm{Fe}(\mathrm{III}), \mathrm{Ni}(\mathrm{II}), \mathrm{Pb}(\mathrm{II})$ and $\mathrm{Zn}(\mathrm{II})$. The recoveries obtained were between 98 and $99 \%$. A column with 2,5-dimercapto-1,3,4-thiadiazole modified silica gel was used to determine $\mathrm{Cu}(\mathrm{II}), \mathrm{Zn}(\mathrm{II}), \mathrm{Cd}(\mathrm{II}), \mathrm{Ni}(\mathrm{II}), \mathrm{Pb}(\mathrm{II}), \mathrm{Co}(\mathrm{II})$ and $\mathrm{Fe}(\mathrm{III})$ in ethanol fuel. Recoveries close to $100 \%$ were found for binary mixtures whereas they were lower for mixtures of all elements (20-30\% for Cd). ${ }^{211}$ Additional adsorbing media have been described such as 2aminothiazole ${ }^{183}$ modified silica gel or $N$-Acyl- $N^{\prime}$-Benzoylthiourea modified silica gel. ${ }^{209}$ Recently, Vieira et al. ${ }^{180}$ have used 2,2'-dipyridylamine bonded silica as a preconcentration system to determine $\mathrm{Fe}(\mathrm{III}), \mathrm{Cr}(\mathrm{III}), \mathrm{Cu}(\mathrm{II}), \mathrm{Co}(\mathrm{II}), \mathrm{Pb}(\mathrm{II}), \mathrm{Ni}(\mathrm{II})$ and $\mathrm{Zn}$ (II) in fuel ethanol through FAAS. The recovery obtained for all the analytes was close to $100 \%$ and accuracy was good with RSD for all elements lower than 3\%. The concentrations found and LODs for all methods proposed ${ }^{180,183,189,210,211}$ are shown in

Table 6. 
Donati et al. ${ }^{181}$ have developed recently a method to determine $\mathrm{Cr}, \mathrm{Ni}, \mathrm{Pb}$ and $\mathrm{V}$ in ethanol fuel through MIP-OES preparing the samples in aqueous media containing $10 \%$ of ethanol and $1 \% \mathrm{HNO}_{3}$ and diluting the samples 10 fold with aqueous $1 \% \mathrm{HNO}_{3}$. The method supplied good precision and accuracy, the recoveries being from 92 to $108 \%$.

Voltammetry can also be useful to determine metals in ethanol fuel and water-ethanol mixtures. A method to determine $\mathrm{Cd}$ in alcohol-water mixtures using an ion-selective electrode was developed by Motonaga et al. ${ }^{213}$ It was found that cadmium ion-selective electrodes could be used to determine $\mathrm{Cd}$ ions in an alcohol-water mixture. Nevertheless, the response time became longer and the dynamic range was narrower as the ethanol content went up. Kamenev et al. ${ }^{214}$ carried out the determination of $\mathrm{Pb}(\mathrm{II})$ in water-alcohol mixtures by Stripping Voltammetry with a modified carbon-Glass-Ceramic electrode. The procedure was based on electrochemical and chemical modification of the surface and provided reproducible results. Another method was based on anodic stripping voltammetry (ASV) ${ }^{187}$ with the aim of determine $\mathrm{Cu}$ and $\mathrm{Pb}$ simultaneously. Two different procedures were applied: the first one was the direct quantification of metals in alcohol-water mixtures whereas the second one involved the evaporation of organic solvent and re-suspension of ions in water + electrolyte. The results obtained with two methods were in good agreement.

A high-performance chelation ionic chromatography was used to develop the quantification of $\mathrm{Fe}^{2+}, \mathrm{Fe}^{3+}, \mathrm{Cu}^{2+}, \mathrm{Mn}^{2+}, \mathrm{Pb}^{2+}, \mathrm{Cd}^{2+}, \mathrm{Co}^{2+}, \mathrm{Zn}^{2+}$ and $\mathrm{Ni}^{2+}$ in fuel ethanol through post-column reaction with 4-(2-pyridylazo)resorcinol and spectrophotometric detection at $510 \mathrm{~nm} .{ }^{182}$ Accuracy and precision were acceptable.

\subsubsection{Speciation}


Only two studies have been developed to carry out the speciation of metals in ethanol fuel. ${ }^{182,215}$ In both cases, high-performance chelation ion chromatography has been employed to separate $\mathrm{Fe}^{2+}, \mathrm{Fe}^{3+}$ and other cations. The chromatographic system is based on a silica column functionalized with iminodiacetic acid (IDA) functional groups and photometric detection at $510 \mathrm{~nm}$ by post-column reaction with 4-(2-pyridylazo)resorcinol (PAR). In the first study, the eluent was a solution containing $2.5 \mathrm{mmol} \mathrm{L}^{-1}$ of DPA and $5 \mathrm{mmol} \mathrm{L}^{-1}$ of $\mathrm{HCl}$ in a mixture $60 \%$ methanol : $40 \%$ water. ${ }^{182}$ In the second one, a solution containing $2 \mathrm{mmol} \mathrm{L}$ ${ }^{1}$ of chelidamic acid (CDA), $3 \mathrm{mmol} \mathrm{L}^{-1}$ of triethylamine (TEA) and $12 \mathrm{mmol} \mathrm{L}^{-1}$ of $\mathrm{HCl}$ in a mixture $50 \%$ methanol : 50\% water was employed as mobile phase. ${ }^{215}$ The recoveries for both iron species went from 90 to $103 \% .^{182,215}$

Table 6. Summary of the limits of detection and found concentrations obtained in fuel ethanol samples by several authors.

\begin{tabular}{|c|c|c|c|c|c|}
\hline Element & Technique & Conditions & $\begin{array}{c}\text { LOD }(\mu g \\
\left.L^{-1}\right)\end{array}$ & $\begin{array}{c}\text { Found } \\
\text { concentration } \\
\left(\mu \mathrm{g} \mathrm{L}^{-1}\right) \\
\text { Range (min-max) }\end{array}$ & Ref \\
\hline \multirow{6}{*}{$\mathrm{Ag}$} & \multirow[t]{2}{*}{ ETV-ICP-MS } & ID & 0.02 & $<0.02-0.079$ & \multirow[t]{2}{*}{185} \\
\hline & & $\mathrm{EC}$ & 0.02 & $<0.02-0.072$ & \\
\hline & ETV-ICP-MS & $\begin{array}{c}\text { EC } \\
\text { (Pd as modifier) }\end{array}$ & 0.013 & $0.041-0.102$ & \multirow[t]{2}{*}{184} \\
\hline & ETV-ICP-MS & $\mathrm{EC}$ & 0.015 & $<0.015-0.072$ & \\
\hline & \multirow[t]{2}{*}{ FI-USN-ICP-MS } & $\mathrm{EC}(\mathrm{W})$ & 0.1 & n.d. & \multirow[t]{2}{*}{39} \\
\hline & & $\mathrm{EC}(\mathrm{MM})$ & 0.07 & n.d. & \\
\hline
\end{tabular}




\begin{tabular}{|c|c|c|c|c|c|}
\hline & & ID & 0.02 & n.d. & \\
\hline & ICP-OES & $\begin{array}{c}\text { EC } \\
\text { Cooled spray } \\
\text { chamber } \\
\text { Ag } 328.028\end{array}$ & 0.47 & n.d. & 177 \\
\hline \multirow{5}{*}{ Al } & CRI-ICP-MS & $\begin{array}{c}\text { IS }(\mathrm{Y}) \\
\mathrm{CRI}\left(\mathrm{H}_{2} \text { through }\right. \\
\text { skimmer) }\end{array}$ & 0.20 & $33-411$ & 193 \\
\hline & ETAAS & $\begin{array}{c}\text { EC (Ethanol 1:1) } \\
\text { THGA with } \\
\mathrm{Pd}\left(\mathrm{NO}_{3}\right)_{2}+\mathrm{Mg} \\
\left(\mathrm{NO}_{3}\right)_{2}\end{array}$ & 1.2 & n.a & 205 \\
\hline & ETAAS & $\begin{array}{c}\text { EC (Ethanol 1:1) } \\
\text { W-Rh permanent } \\
\text { modifier and } \\
\mathrm{Pd}\left(\mathrm{NO}_{3}\right)_{2}+ \\
\mathrm{Mg}\left(\mathrm{NO}_{3}\right)_{2}\end{array}$ & 1.9 & n.a & 204 \\
\hline & ICP-OES & $\begin{array}{c}\text { EC } \\
\text { Cooled spray } \\
\text { chamber } \\
\text { Al } 167.020\end{array}$ & 0.15 & n.a & 177 \\
\hline & ICP-OES & $\begin{array}{c}\text { EC } \\
\text { Cooled spray }\end{array}$ & 2.68 & n.a & 177 \\
\hline
\end{tabular}




\begin{tabular}{|c|c|c|c|c|c|}
\hline & & $\begin{array}{l}\text { chamber } \\
\text { Al } 396.152\end{array}$ & & & \\
\hline \multirow{8}{*}{ As } & ETV-ICP-MS & $\begin{array}{c}\mathrm{EC} \\
\text { ( } \mathrm{Pd} \text { as modifier) }\end{array}$ & 0.02 & $0.23-2.84$ & 184 \\
\hline & ETV-ICP-MS & EC & 0.04 & $<0.04-2.03$ & \\
\hline & ETAAS & $\begin{array}{c}\text { EC (Ethanol 1:1) } \\
\text { THGA with } \\
\mathrm{Pd}\left(\mathrm{NO}_{3}\right)_{2}+\mathrm{Mg} \\
\left(\mathrm{NO}_{3}\right)_{2}\end{array}$ & 2.5 & n.d. & 205 \\
\hline & ETAAS & $\begin{array}{c}\text { EC (Ethanol 1:1) } \\
\text { W-Rh permanent } \\
\text { modifier and } \\
\mathrm{Pd}\left(\mathrm{NO}_{3}\right)_{2}+ \\
\mathrm{Mg}\left(\mathrm{NO}_{3}\right)_{2}\end{array}$ & 2.9 & n.d. & 204 \\
\hline & ETAAS & $\begin{array}{c}E C \\
\text { Ru as modifier }\end{array}$ & 0.7 & n.d. & 206 \\
\hline & ETAAS & $\begin{array}{c}\text { EC } \\
\mathrm{Ir}+\mathrm{Rh} \text { as modifier }\end{array}$ & 2.0 & $<2.0-2.7$ & 207 \\
\hline & ICP-OES & $\begin{array}{c}\text { EC } \\
\text { Cooled spray } \\
\text { chamber } \\
\text { As } 189.042\end{array}$ & 2.22 & n.d. & 177 \\
\hline & MCN-ICP-MS & $\mathrm{EC}$ and $\mathrm{Y}, \mathrm{Ir}$ and $\mathrm{Rh}$ & $0.01-$ & $1.13-3.62^{2}$ & 190 \\
\hline
\end{tabular}




\begin{tabular}{|c|c|c|c|c|c|}
\hline & & as IS & $0.03^{1}$ & & \\
\hline B & ICP-OES & $\begin{array}{c}\text { EC } \\
\text { Cooled spray } \\
\text { chamber } \\
\text { B } 249.773\end{array}$ & 1.42 & n.d. & 177 \\
\hline \multirow[t]{2}{*}{$\mathrm{Ba}$} & ICP-OES & $\begin{array}{c}\text { EC } \\
\text { Cooled spray } \\
\text { chamber } \\
\text { Ba } 455.403\end{array}$ & 0.04 & n.d. & 177 \\
\hline & CRI-ICP-MS & $\begin{array}{c}\text { IS }(\mathrm{Y}) \\
\text { CRI ( } \mathrm{H}_{2} \text { through } \\
\text { skimmer) }\end{array}$ & 0.11 & $<0.11$ & 193 \\
\hline $\mathrm{Be}$ & ICP-OES & $\begin{array}{c}\text { EC } \\
\text { Cooled spray } \\
\text { chamber } \\
\text { Be } 313.042\end{array}$ & 0.21 & n.d. & 177 \\
\hline $\mathbf{B i}$ & MCN-ICP-MS & $\begin{array}{c}\mathrm{EC} \text { and } \mathrm{Y}, \mathrm{Ir} \text { and } \mathrm{Rh} \\
\text { as IS }\end{array}$ & $0.02^{1}$ & $<0.02-0.17^{2}$ & 190 \\
\hline $\mathrm{Ca}$ & ICP-OES & $\begin{array}{c}\text { EC } \\
\text { Cooled spray } \\
\text { chamber } \\
\text { Ca } 317.933\end{array}$ & 1.56 & n.d. & 177 \\
\hline $\mathrm{Cd}$ & ETV-ICP-MS & ID & 0.08 & $<0.08-0.53$ & 185 \\
\hline
\end{tabular}




\begin{tabular}{|c|c|c|c|c|}
\hline & (Pd as modifier) & & & \\
\hline & $\begin{array}{c}\text { EC } \\
\text { (Pd as modifier) }\end{array}$ & 0.07 & $<0.07-0.54$ & \\
\hline ETV-ICP-MS & $\begin{array}{c}\text { EC } \\
\text { (Pd as modifier) }\end{array}$ & 0.07 & $<0.07-1.15$ & 184 \\
\hline ETV-ICP-MS & EC & 0.13 & $<0.13-1.05$ & \\
\hline \multirow{3}{*}{ FI-USN-ICP-MS } & $\mathrm{EC}(\mathrm{W})$ & 0.2 & n.d. & \multirow{3}{*}{39} \\
\hline & $\mathrm{EC}(\mathrm{MM})$ & 0.03 & n.d. & \\
\hline & ID & 0.02 & n.d. & \\
\hline FAAS & $\begin{array}{c}\text { EC } \\
\text { Using Moringa } \\
\text { oleifera seeds as a } \\
\text { biosorbent }\end{array}$ & 5.50 & n.d. & 189 \\
\hline ETAAS & $\begin{array}{c}\text { EC } \\
\text { Ir }+ \text { Rh as modifier }\end{array}$ & 0.05 & $<0.05-3.0$ & 207 \\
\hline ETAAS & $\begin{array}{l}\text { EC with pure } \\
\text { ethanol } \\
\text { Filter-ETAAS }\end{array}$ & 0.1 & $<0.1-0.83$ & 208 \\
\hline ICP-OES & $\begin{array}{c}\text { EC } \\
\text { Cooled spray } \\
\text { chamber } \\
\text { Cd } 228.802\end{array}$ & 0.17 & n.d. & 177 \\
\hline MCN-ICP-MS & $\mathrm{EC}$ and $\mathrm{Y}, \mathrm{Ir}$ and $\mathrm{Rh}$ & $0.03-$ & $<0.05^{2}$ & 190 \\
\hline
\end{tabular}




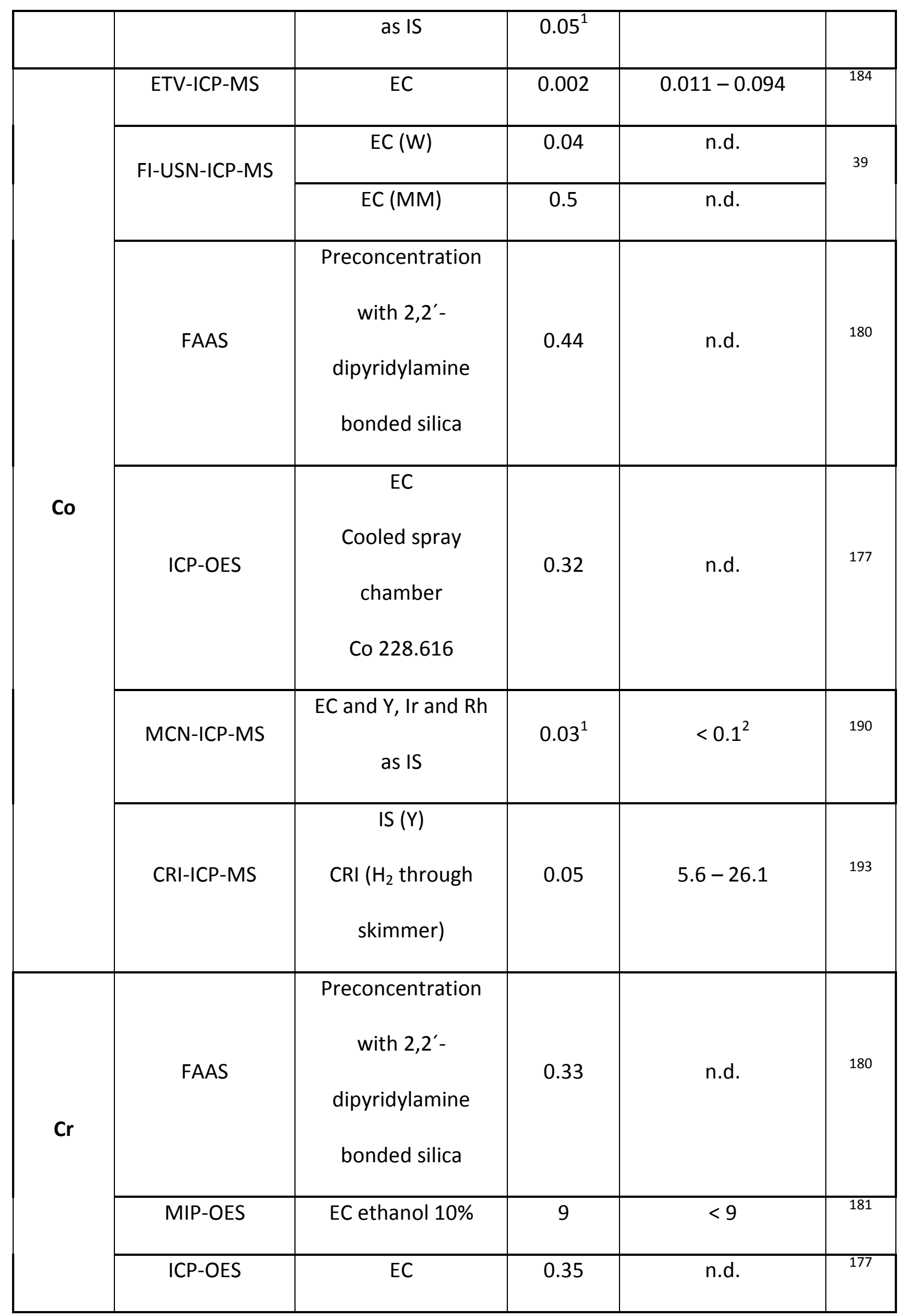




\begin{tabular}{|c|c|c|c|c|c|}
\hline & & $\begin{array}{l}\text { cooled spray } \\
\text { chamber } \\
\text { Cr } 267.716\end{array}$ & & & \\
\hline & USN-CD-ICP-OES & $\mathrm{EC}$ & 0.8 & n.d. & 197 \\
\hline & CRI-ICP-MS & $\begin{array}{c}\text { IS }(\mathrm{Y}) \\
\mathrm{CRI}\left(\mathrm{H}_{2} \text { through }\right. \\
\text { skimmer) }\end{array}$ & 0.18 & $12.3-77.2$ & 193 \\
\hline \multirow{9}{*}{$\mathrm{Cu}$} & \multirow[t]{2}{*}{ ETV-ICP-MS } & ID & 0.1 & $1.96-14.44$ & \multirow[t]{2}{*}{185} \\
\hline & & $\mathrm{EC}$ & 0.2 & $1.80-14.98$ & \\
\hline & ETV-ICP-MS & EC & 0.22 & $1.80-14.98$ & \multirow{2}{*}{184} \\
\hline & ETAAS & EC & n.a. & $2.15-13.93$ & \\
\hline & FAAS & $\begin{array}{l}\text { 5-amino-1,3,4- } \\
\text { thiadiazole-2-thiol } \\
\text { modified silica gel } \\
\text { preconcentrated }\end{array}$ & n.a. & $52-78$ & 210 \\
\hline & FAAS & $\begin{array}{c}\text { Preconcentrated by } \\
\text { evaporation }\end{array}$ & n.a. & $49-76$ & 210 \\
\hline & FAAS & $\begin{array}{l}\text { Preconcentrated by } \\
\text { 2,5-dimercapto- } \\
\text { 1,3,4-thiadiazole }\end{array}$ & n.a. & $\begin{array}{l}11-190 * \\
\text { *5000 for a sample } \\
\text { in a copper } \\
\text { distillation column }\end{array}$ & 211 \\
\hline & \multirow{2}{*}{ FI-USN-ICP-MS } & EC (W) & 0.4 & n.d. & \multirow[t]{2}{*}{39} \\
\hline & & EC (MM) & 0.8 & n.d. & \\
\hline
\end{tabular}




\begin{tabular}{|c|c|c|c|c|}
\hline & ID & 0.2 & n.d. & \\
\hline FAAS & $\begin{array}{l}\text { Preconcentrated } \\
\text { with 2- } \\
\text { aminothiazole } \\
\text { modified silica gel }\end{array}$ & 1.7 & $5.4-7.3$ & 183 \\
\hline FAAS & $\begin{array}{l}\text { Preconcentrated } \\
\text { with 2- } \\
\text { aminothiazole } \\
\text { modified silica gel }\end{array}$ & n.a. & $5.4-7.3$ & 183 \\
\hline FAAS & $\begin{array}{l}\text { Preconcentration } \\
\text { with } 2,2^{\prime}- \\
\text { dipyridylamine } \\
\text { bonded silica }\end{array}$ & 0.40 & $51-66$ & 180 \\
\hline FAAS & $\begin{array}{c}\text { Preconcentrated by } \\
\text { evaporation }\end{array}$ & n.a. & $49-57$ & 180 \\
\hline ETAAS & $\begin{array}{c}\text { EC (Ethanol 1:1) } \\
\text { THGA with } \\
\mathrm{Pd}\left(\mathrm{NO}_{3}\right)_{2}+\mathrm{Mg} \\
\left(\mathrm{NO}_{3}\right)_{2}\end{array}$ & 0.22 & n.d. & 205 \\
\hline ETAAS & $\begin{array}{c}\text { EC (Ethanol 1:1) } \\
\text { W-Rh permanent } \\
\text { modifier and } \\
\mathrm{Pd}\left(\mathrm{NO}_{3}\right)_{2}+\end{array}$ & 0.57 & n.d. & 204 \\
\hline
\end{tabular}




\begin{tabular}{|c|c|c|c|c|}
\hline & $\mathrm{Mg}\left(\mathrm{NO}_{3}\right)_{2}$ & & & \\
\hline ETAAS & $\begin{array}{c}\text { EC } \\
\text { Without modifier }\end{array}$ & 0.6 & $2.15-13.93$ & 206 \\
\hline GFASS & $\begin{array}{l}\text { W permanent } \\
\text { modifier + co- } \\
\text { injection of Ir }\end{array}$ & 0.086 & $8.0-47$ & 179 \\
\hline FAAS & $\begin{array}{l}\text { EC } \\
\text { Preconcentration } \\
\text { with } N \text {-Acyl-N- } \\
\text { Benzoylthiourea } \\
\text { modified silica gel }\end{array}$ & n.a. & $6.9-7.2$ & 209 \\
\hline ASV & $\begin{array}{l}\text { IS } \\
\text { Evaporation of } \\
\text { ethanol and } \\
\text { redisolution in } \\
\text { aqueous media }\end{array}$ & 0.120 & $13.3-20.1$ & 187 \\
\hline $\mathrm{HPCIC}$ & $\mathrm{EC}\left(\mathrm{Cu}^{2+}\right)$ & 7.4 & n.d. & 182 \\
\hline ICP-OES & $\begin{array}{c}\text { EC } \\
\text { Colled spray } \\
\text { chamber } \\
\text { Cu } 324.754 \mathrm{~nm}\end{array}$ & 1.5 & n.d. & 176 \\
\hline ICP-OES & $\begin{array}{c}\text { EC } \\
\text { cooled spray }\end{array}$ & 0.28 & n.d. & 177 \\
\hline
\end{tabular}




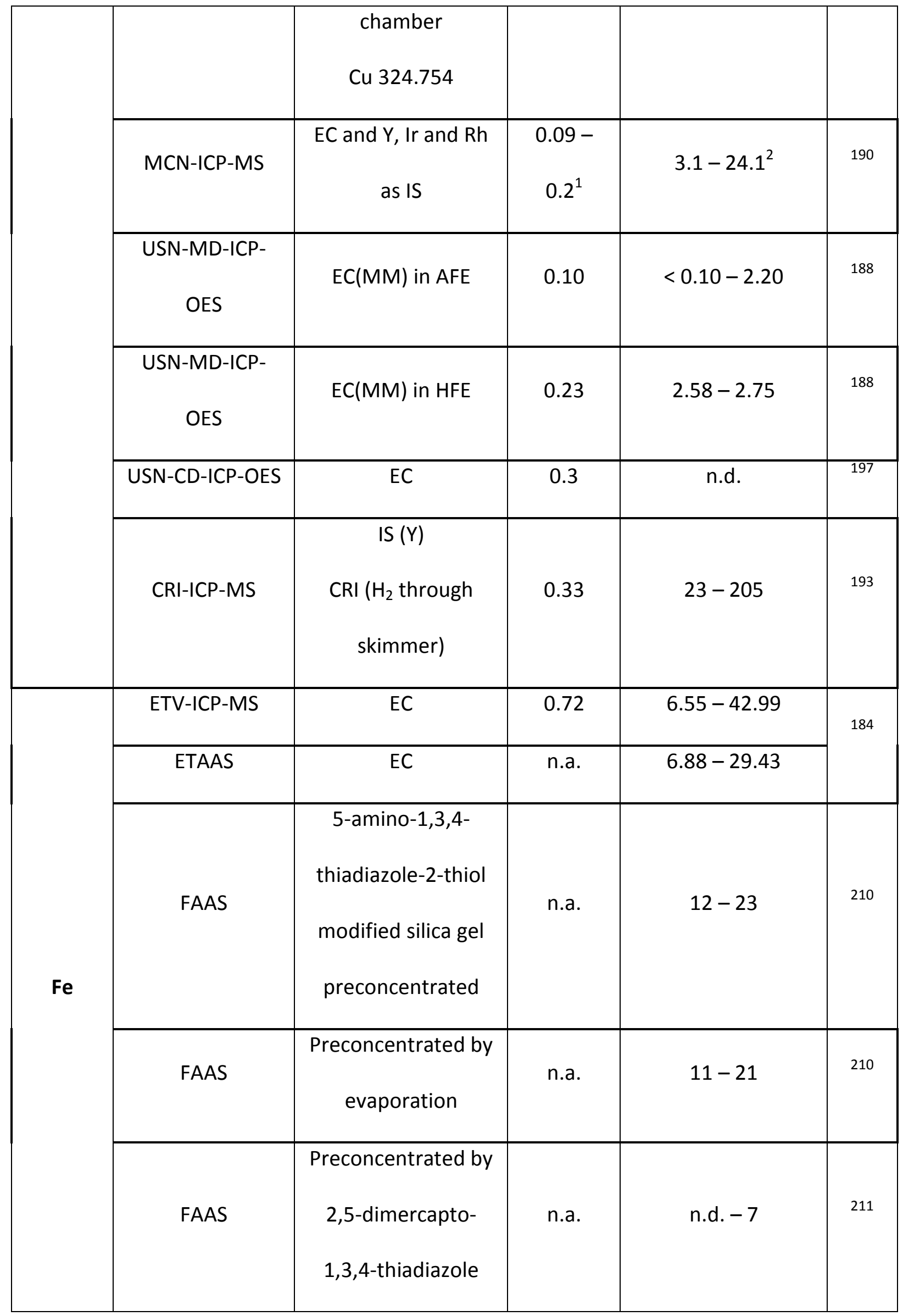




\begin{tabular}{|c|c|c|c|c|}
\hline \multirow{2}{*}{ FI-USN-ICP-MS } & $\mathrm{EC}(\mathrm{W})$ & 27 & n.d. & \multirow{2}{*}{39} \\
\hline & EC (MM) & 10 & n.d. & \\
\hline FAAS & $\begin{array}{c}\text { Preconcentration } \\
\text { with } 2,2^{\prime}- \\
\text { dipyridylamine } \\
\text { bonded silica }\end{array}$ & 0.28 & $10-25$ & 180 \\
\hline FAAS & $\begin{array}{c}\text { Preconcentrated by } \\
\text { evaporation }\end{array}$ & n.a. & $11-21$ & 180 \\
\hline ETAAS & $\begin{array}{c}\text { EC (Ethanol 1:1) } \\
\text { THGA with } \\
\mathrm{Pd}\left(\mathrm{NO}_{3}\right)_{2}+\mathrm{Mg} \\
\left(\mathrm{NO}_{3}\right)_{2}\end{array}$ & 1.6 & n.d. & 205 \\
\hline ETAAS & $\begin{array}{c}\text { EC (Ethanol 1:1) } \\
\text { W-Rh permanent } \\
\text { modifier and } \\
\mathrm{Pd}\left(\mathrm{NO}_{3}\right)_{2}+ \\
\mathrm{Mg}\left(\mathrm{NO}_{3}\right)_{2}\end{array}$ & 1.3 & n.d. & 204 \\
\hline ETAAS & $\begin{array}{c}\text { EC } \\
\text { Without modifier }\end{array}$ & 1.4 & $6.88-29.43$ & 206 \\
\hline $\mathrm{HPClC}$ & $\mathrm{EC}\left(\mathrm{Fe}^{3+}\right)$ & 8.9 & n.d. & 182 \\
\hline ICP-OES & $\begin{array}{c}\mathrm{EC} \\
\text { cooled spray } \\
\text { chamber }\end{array}$ & 0.52 & n.d. & 177 \\
\hline
\end{tabular}




\begin{tabular}{|c|c|c|c|c|c|}
\hline & & Fe 259.940 & & & \\
\hline & MCN-ICP-MS & $\begin{array}{c}\text { EC and } \mathrm{Y}, \mathrm{Ir} \text { and } \mathrm{Rh} \\
\text { as IS }\end{array}$ & $0.7-4^{1}$ & $<4-18^{2}$ & 190 \\
\hline & $\begin{array}{c}\text { USN-MD-ICP- } \\
\text { OES }\end{array}$ & $E C(M M)$ in $A F E$ & 0.20 & $<0.20-13.95$ & 188 \\
\hline & $\begin{array}{c}\text { USN-MD-ICP- } \\
\text { OES }\end{array}$ & $\mathrm{EC}(\mathrm{MM})$ in $\mathrm{HFE}$ & 0.50 & $5.34-5.80$ & 188 \\
\hline & ID-ICP-MS & ID in AFE & n.a. & 14.20 & 188 \\
\hline & ID-ICP-MS & ID in HFE & n.a. & $5.30-5.75$ & 188 \\
\hline & USN-CD-ICP-OES & EC & 0.6 & n.d. & 197 \\
\hline & CRI-ICP-MS & $\begin{array}{c}\text { IS }(\mathrm{Y}) \\
\mathrm{CRI}\left(\mathrm{H}_{2} \text { through }\right. \\
\text { skimmer) }\end{array}$ & 0.10 & 6- 124 & 193 \\
\hline Ga & MCN-ICP-MS & $\begin{array}{c}\mathrm{EC} \text { and } \mathrm{Y}, \mathrm{Ir} \text { and } \mathrm{Rh} \\
\text { as IS }\end{array}$ & $\begin{array}{l}0.06- \\
0.2^{1}\end{array}$ & $<0.2^{2}$ & 190 \\
\hline $\mathrm{Hg}$ & ICP-OES & $\begin{array}{c}\text { EC } \\
\text { cooled spray } \\
\text { chamber } \\
\text { Hg } 194.163\end{array}$ & 1.80 & n.d. & 177 \\
\hline K & ICP-OES & $\begin{array}{c}\text { EC } \\
\text { cooled spray } \\
\text { chamber } \\
\text { K } 766.490\end{array}$ & 29.67 & n.d. & 177 \\
\hline
\end{tabular}




\begin{tabular}{|c|c|c|c|c|c|}
\hline Li & ICP-OES & $\begin{array}{c}\text { EC } \\
\text { cooled spray } \\
\text { chamber } \\
\text { Li } 670.784\end{array}$ & 0.65 & n.d. & 177 \\
\hline \multirow[t]{2}{*}{ Mg } & ICP-OES & $\begin{array}{c}\text { EC } \\
\text { cooled spray } \\
\text { chamber } \\
\text { Mg } 279.806\end{array}$ & 4.01 & n.d. & 177 \\
\hline & CRI-ICP-MS & $\begin{array}{c}\text { IS }(\mathrm{Y}) \\
\mathrm{CRI}\left(\mathrm{H}_{2} \text { through }\right. \\
\text { skimmer) }\end{array}$ & 0.24 & $17-204$ & 193 \\
\hline \multirow{4}{*}{$\mathrm{Mn}$} & ETV-ICP-MS & $\mathrm{EC}$ & 0.025 & $0.884-1.306$ & 184 \\
\hline & FI-USN-ICP-MS & $\begin{array}{c}\mathrm{EC}(\mathrm{W}) \\
\mathrm{EC}(\mathrm{MM})\end{array}$ & $\begin{array}{l}0.7 \\
0.8\end{array}$ & $\begin{array}{l}\text { n.d. } \\
\text { n.d. }\end{array}$ & 39 \\
\hline & ETAAS & $\begin{array}{c}\text { EC (Ethanol 1:1) } \\
\text { THGA with } \\
\mathrm{Pd}\left(\mathrm{NO}_{3}\right)_{2}+\mathrm{Mg} \\
\left(\mathrm{NO}_{3}\right)_{2}\end{array}$ & 0.20 & n.d. & 205 \\
\hline & ETAAS & $\begin{array}{c}\text { EC (Ethanol 1:1) } \\
\text { W-Rh permanent } \\
\text { modifier and } \\
\mathrm{Pd}\left(\mathrm{NO}_{3}\right)_{2}+ \\
\mathrm{Mg}\left(\mathrm{NO}_{3}\right)_{2}\end{array}$ & 0.40 & n.d. & 204 \\
\hline
\end{tabular}




\begin{tabular}{|c|c|c|c|c|c|}
\hline & ICP-OES & $\begin{array}{c}\text { EC } \\
\text { cooled spray } \\
\text { chamber } \\
\text { Mn } 257.610\end{array}$ & 0.13 & n.d. & 177 \\
\hline & MCN-ICP-MS & $\begin{array}{c}\text { EC and } \mathrm{Y}, \mathrm{Ir} \text { and } \mathrm{Rh} \\
\text { as IS }\end{array}$ & $\begin{array}{l}0.02- \\
0.4^{1}\end{array}$ & $0.77-1.25$ & 190 \\
\hline & CRI-ICP-MS & $\begin{array}{c}\text { IS }(\mathrm{Y}) \\
\mathrm{CRI}\left(\mathrm{H}_{2} \text { through }\right. \\
\text { skimmer) }\end{array}$ & 0.02 & $1.7-15.4$ & 193 \\
\hline \multirow{3}{*}{ Mo } & ICP-OES & $\begin{array}{c}\text { EC } \\
\text { cooled spray } \\
\text { chamber } \\
\text { Mo } 202.030\end{array}$ & 0.45 & n.d. & 177 \\
\hline & MCN-ICP-MS & $\begin{array}{c}\text { EC and } Y, \text { Ir and Rh } \\
\text { as IS }\end{array}$ & $0.03^{1}$ & $<0.03-0.46^{2}$ & 190 \\
\hline & CRI-ICP-MS & $\begin{array}{c}\text { IS }(\mathrm{Y}) \\
\mathrm{CRI}\left(\mathrm{H}_{2} \text { through }\right. \\
\text { skimmer) }\end{array}$ & 0.05 & $<0.05$ & 193 \\
\hline \multirow[t]{2}{*}{$\mathrm{Na}$} & ICP-OES & $\begin{array}{c}\text { EC } \\
\text { cooled spray } \\
\text { chamber } \\
\text { Na } 589.592\end{array}$ & 4.96 & n.d. & 177 \\
\hline & CRI-ICP-MS & IS $(Y)$ & 0.80 & $54-184$ & 193 \\
\hline
\end{tabular}




\begin{tabular}{|c|c|c|c|c|c|}
\hline & & $\begin{array}{c}\mathrm{CRI}\left(\mathrm{H}_{2} \text { through }\right. \\
\text { skimmer })\end{array}$ & & & \\
\hline \multirow{9}{*}{$\mathbf{N i}$} & ETV-ICP-MS & EC & 0.026 & $0.096-0.477$ & 184 \\
\hline & FAAS & $\begin{array}{l}\text { 5-amino-1,3,4- } \\
\text { thiadiazole-2-thiol } \\
\text { modified silica gel } \\
\text { preconcentrated }\end{array}$ & n.a. & $8-14$ & 210 \\
\hline & FAAS & $\begin{array}{c}\text { Preconcentrated by } \\
\text { evaporation }\end{array}$ & n.a. & $10-13$ & 210 \\
\hline & FAAS & $\begin{array}{l}\text { Preconcentrated by } \\
\text { 2,5-dimercapto- } \\
\text { 1,3,4-thiadiazole }\end{array}$ & n.a. & $5-45$ & 211 \\
\hline & \multirow[t]{2}{*}{ FI-USN-ICP-MS } & $\mathrm{EC}(\mathrm{W})$ & 0.4 & n.d. & \multirow[t]{2}{*}{39} \\
\hline & & EC (MM) & 2.5 & n.d. & \\
\hline & FAAS & $\begin{array}{l}\text { Preconcentrated } \\
\text { with 2- } \\
\text { aminothiazole } \\
\text { modified silica gel }\end{array}$ & 2.3 & $4.4-5.6$ & 183 \\
\hline & ETAAS & EC & n.a. & $4.1-6.1$ & 183 \\
\hline & FAAS & $\begin{array}{l}\text { Preconcentration } \\
\text { with } 2,2^{\prime}- \\
\text { dipyridylamine } \\
\text { bonded silica }\end{array}$ & 0.51 & $9-15$ & 180 \\
\hline
\end{tabular}




\begin{tabular}{|c|c|c|c|c|c|}
\hline & FAAS & $\begin{array}{c}\text { Preconcentrated by } \\
\text { evaporation }\end{array}$ & n.a. & $10-13$ & 180 \\
\hline & ETAAS & $\begin{array}{c}\text { EC (Ethanol 1:1) } \\
\text { THGA with } \\
\mathrm{Pd}\left(\mathrm{NO}_{3}\right)_{2}+\mathrm{Mg} \\
\left(\mathrm{NO}_{3}\right)_{2}\end{array}$ & 1.1 & n.d. & 205 \\
\hline & ETAAS & $\begin{array}{c}\text { EC (Ethanol 1:1) } \\
\text { W-Rh permanent } \\
\text { modifier and } \\
\mathrm{Pd}\left(\mathrm{NO}_{3}\right)_{2}+ \\
\mathrm{Mg}\left(\mathrm{NO}_{3}\right)_{2}\end{array}$ & 1.3 & n.d. & 204 \\
\hline & MIP-OES & EC ethanol $10 \%$ & 300 & $<300$ & 181 \\
\hline & ICP-OES & $\begin{array}{c}\text { EC } \\
\text { cooled spray } \\
\text { chamber } \\
\text { Ni } 221.647\end{array}$ & 0.30 & n.d. & 177 \\
\hline & MCN-ICP-MS & $\begin{array}{c}\mathrm{EC} \text { and } \mathrm{Y}, \mathrm{Ir} \text { and } \mathrm{Rh} \\
\text { as IS }\end{array}$ & $0.1-0.5^{1}$ & $<0.5^{2}$ & 190 \\
\hline & CRI-ICP-MS & $\begin{array}{c}\text { IS }(\mathrm{Y}) \\
\mathrm{CRI}\left(\mathrm{H}_{2} \text { through }\right. \\
\text { skimmer) }\end{array}$ & 0.17 & $14-73$ & 193 \\
\hline $\mathbf{P}$ & ICP-OES & $\begin{array}{c}\text { EC } \\
\text { Colled sprat }\end{array}$ & 11 & n.d. & 176 \\
\hline
\end{tabular}




\begin{tabular}{|c|c|c|c|c|c|}
\hline & & $\begin{array}{c}\text { chamber } \\
\text { P } 177.495 \mathrm{~nm}\end{array}$ & & & \\
\hline & ICP-OES & $\begin{array}{c}\text { EC } \\
\text { cooled spray } \\
\text { chamber } \\
\text { P } 177.440\end{array}$ & 4.92 & n.d. & 177 \\
\hline & ICP-OES & $\begin{array}{c}\text { EC } \\
\text { cooled spray } \\
\text { chamber } \\
\text { P } 178.229\end{array}$ & 4.32 & n.d. & 177 \\
\hline & ICP-OES & $\begin{array}{c}\text { EC } \\
\text { cooled spray } \\
\text { chamber } \\
\text { P } 213.618\end{array}$ & 2.63 & n.d. & 177 \\
\hline \multirow{6}{*}{$\mathrm{Pb}$} & \multirow{2}{*}{ ETV-ICP-MS } & $\begin{array}{c}\text { ID } \\
\text { (Pd as modifier) }\end{array}$ & 0.05 & $0.62-1.58$ & \multirow[t]{2}{*}{185} \\
\hline & & $\begin{array}{c}\mathrm{EC} \\
\text { (Pd as modifier) }\end{array}$ & 0.02 & $0.51-1.51$ & \\
\hline & ETV-ICP-MS & $\begin{array}{c}\text { EC } \\
\text { (Pd as modifier) }\end{array}$ & 0.02 & $0.57-1.50$ & 184 \\
\hline & ETV-ICP-MS & EC & 0.03 & $0.39-1.51$ & \\
\hline & \multirow[t]{2}{*}{ FI-USN-ICP-MS } & $\mathrm{EC}(\mathrm{W})$ & 0.2 & n.d. & \multirow[t]{2}{*}{39} \\
\hline & & $\mathrm{EC}(\mathrm{MM})$ & 0.1 & n.d. & \\
\hline
\end{tabular}




\begin{tabular}{|c|c|c|c|c|}
\hline & ID & 0.04 & n.d. & \\
\hline FAAS & $\begin{array}{c}\text { Preconcentration } \\
\text { with } 2,2^{\prime}- \\
\text { dipyridylamine } \\
\text { bonded silica }\end{array}$ & 0.55 & n.d. & 180 \\
\hline ETAAS & $\begin{array}{c}\text { EC } \\
\text { Ru as modifier }\end{array}$ & 0.7 & n.d. & 206 \\
\hline ETAAS & $\begin{array}{c}\mathrm{EC} \\
\mathrm{NH}_{4} \mathrm{H}_{2} \mathrm{PO}_{4} \text { as } \\
\text { modifier }\end{array}$ & 0.7 & n.d. & 206 \\
\hline ETAAS & $\begin{array}{c}\text { EC } \\
\text { Ir }+ \text { Rh as modifier }\end{array}$ & 1.1 & $<1.1-6.4$ & 207 \\
\hline ETAAS & $\begin{array}{c}\text { EC with pure } \\
\text { ethanol } \\
\text { Filter-ETAAS }\end{array}$ & 0.3 & $<0.3-1.16$ & 208 \\
\hline GFASS & $\begin{array}{l}\text { W permanent } \\
\text { modifier + co- } \\
\text { injection of Ir }\end{array}$ & 2.47 & $<2.47$ & 179 \\
\hline ASV & $\begin{array}{l}\text { IS } \\
\text { Evaporation of } \\
\text { ethanol and } \\
\text { redisolution in } \\
\text { aqueous media }\end{array}$ & 0.235 & $<0.235-1.43$ & 187 \\
\hline
\end{tabular}




\begin{tabular}{|c|c|c|c|c|c|}
\hline & MIP-OES & EC ethanol $10 \%$ & 500 & $<500$ & 181 \\
\hline & ICP-OES & $\begin{array}{c}\text { EC } \\
\text { cooled spray } \\
\text { chamber } \\
\text { Pb } 220.353\end{array}$ & 1.68 & n.d. & 177 \\
\hline & MCN-ICP-MS & $\begin{array}{c}\mathrm{EC} \text { and } \mathrm{Y}, \mathrm{Ir} \text { and } \mathrm{Rh} \\
\text { as IS }\end{array}$ & $0.03^{1}$ & $<0.03-1.08^{2}$ & 190 \\
\hline & USN-CD-ICP-OES & EC & 5 & n.d. & 197 \\
\hline & CRI-ICP-MS & $\begin{array}{c}\text { IS }(\mathrm{Y}) \\
\mathrm{CRI}\left(\mathrm{H}_{2} \text { through }\right. \\
\text { skimmer) }\end{array}$ & 0.01 & $5.6-38$ & 193 \\
\hline Rb & MCN-ICP-MS & $\begin{array}{c}\text { EC and } Y, \text { Ir and Rh } \\
\text { as IS }\end{array}$ & $0.03^{1}$ & $<0.1^{2}$ & 190 \\
\hline & ICP-OES & $\begin{array}{c}\text { EC } \\
\text { Colled sprat } \\
\text { chamber } \\
\text { S } 180.731\end{array}$ & 21 & n.d. & 176 \\
\hline & ICP-OES & $\begin{array}{c}\text { EC } \\
\text { cooled spray } \\
\text { chamber } \\
\text { S } 180.676\end{array}$ & 5.13 & n.d. & 177 \\
\hline Sb & ETAAS & $\begin{array}{c}\text { EC } \\
\text { Ru as modifier }\end{array}$ & 1.8 & n.d. & 206 \\
\hline
\end{tabular}




\begin{tabular}{|c|c|c|c|c|c|}
\hline & ICP-OES & $\begin{array}{c}\text { EC } \\
\text { cooled spray } \\
\text { chamber } \\
\text { Sb } 206.833\end{array}$ & 2.30 & n.d. & 177 \\
\hline & MCN-ICP-MS & $\begin{array}{c}\text { EC and } Y, \text { Ir and Rh } \\
\text { as IS }\end{array}$ & $0.02^{1}$ & n.d. & 190 \\
\hline & CRI-ICP-MS & $\begin{array}{c}\text { IS }(\mathrm{Y}) \\
\mathrm{CRI}\left(\mathrm{H}_{2} \text { through }\right. \\
\text { skimmer) }\end{array}$ & 0.11 & $<0.11$ & 193 \\
\hline Se & ICP-OES & $\begin{array}{c}\text { EC } \\
\text { cooled spray } \\
\text { chamber } \\
\text { Se } 196.026\end{array}$ & 39.63 & n.d. & 177 \\
\hline & MCN-ICP-MS & IS $(Y)$ & 0.6 & $1.8-3.3$ & 190 \\
\hline \multirow[t]{2}{*}{ Si } & ICP-OES & $\begin{array}{c}\text { EC } \\
\text { cooled spray } \\
\text { chamber } \\
\text { Si } 251.611\end{array}$ & 1.84 & n.d. & 177 \\
\hline & CRI-ICP-MS & $\begin{array}{c}\text { IS }(\mathrm{Y}) \\
\mathrm{CRI}\left(\mathrm{H}_{2} \text { through }\right. \\
\text { skimmer) }\end{array}$ & 14 & $<14$ & 193 \\
\hline Sn & ETV-ICP-MS & $\begin{array}{c}\text { EC } \\
\text { (Pd as modifier) }\end{array}$ & 0.010 & $<0.010-0.062$ & 184 \\
\hline
\end{tabular}




\begin{tabular}{|c|c|c|c|c|c|}
\hline & ETV-ICP-MS & EC & 0.007 & $<0.007-0.067$ & \\
\hline & ETAAS & $\begin{array}{c}\text { EC } \\
\text { Ru as modifier }\end{array}$ & 3.8 & n.d. & 206 \\
\hline & ICP-OES & $\begin{array}{c}\text { EC } \\
\text { cooled spray } \\
\text { chamber } \\
\text { Sn } 189.989\end{array}$ & 2.83 & n.d. & 177 \\
\hline & MCN-ICP-MS & $\begin{array}{c}\text { EC and } Y \text {, Ir and Rh } \\
\text { as IS }\end{array}$ & $0.09^{1}$ & $<0.09^{2}$ & 190 \\
\hline \multirow[t]{2}{*}{ Sr } & ICP-OES & $\begin{array}{c}\text { EC } \\
\text { cooled spray } \\
\text { chamber } \\
\text { Sr } 407.771\end{array}$ & 0.01 & n.d. & 177 \\
\hline & MCN-ICP-MS & $\begin{array}{c}\mathrm{EC} \text { and } \mathrm{Y}, \mathrm{Ir} \text { and } \mathrm{Rh} \\
\text { as IS }\end{array}$ & $\begin{array}{l}0.01- \\
0.03^{1}\end{array}$ & $<0.03^{2}$ & 190 \\
\hline $\mathrm{Ti}$ & ICP-OES & $\begin{array}{c}\text { EC } \\
\text { cooled spray } \\
\text { chamber } \\
\text { Ti } 337.280\end{array}$ & 0.13 & n.d. & 177 \\
\hline \multirow{2}{*}{ TI } & \multirow{2}{*}{ ETV-ICP-MS } & $\begin{array}{c}\text { ID } \\
\text { (Pd as modifier) }\end{array}$ & 0.001 & $<0.001-0.0047$ & \multirow[t]{2}{*}{185} \\
\hline & & $\begin{array}{c}\text { EC } \\
\text { (Pd as modifier) }\end{array}$ & 0.0008 & $<0.0008-0.0045$ & \\
\hline
\end{tabular}




\begin{tabular}{|c|c|c|c|c|c|}
\hline & ETV-ICP-MS & $\begin{array}{c}\text { EC } \\
\text { (Pd as modifier) }\end{array}$ & 0.0008 & $<0.0008-0.0045$ & 184 \\
\hline & ETV-ICP-MS & EC & 0.0009 & $<0.0009-0.0045$ & \\
\hline & ICP-OES & $\begin{array}{c}\text { EC } \\
\text { cooled spray } \\
\text { chamber } \\
\text { TI } 190.864\end{array}$ & 2.66 & n.d. & 177 \\
\hline & MCN-ICP-MS & $\begin{array}{c}\mathrm{EC} \text { and } \mathrm{Y}, \mathrm{Ir} \text { and } \mathrm{Rh} \\
\text { as IS }\end{array}$ & $0.01^{1}$ & $<0.01^{2}$ & 190 \\
\hline \multirow{4}{*}{ V } & MIP-OES & EC ethanol $10 \%$ & 4 & $<4$ & 181 \\
\hline & ICP-OES & $\begin{array}{c}\text { EC } \\
\text { cooled spray } \\
\text { chamber } \\
\text { V } 292.402\end{array}$ & 3.59 & n.d. & 177 \\
\hline & MCN-ICP-MS & $\begin{array}{c}\text { EC and } Y, \text { Ir and Rh } \\
\text { as IS }\end{array}$ & $\begin{array}{c}0.06- \\
0.5^{1}\end{array}$ & $<0.5^{2}$ & 190 \\
\hline & CRI-ICP-MS & $\begin{array}{c}\text { IS }(\mathrm{Y}) \\
\text { CRI }\left(\mathrm{H}_{2} \text { through }\right. \\
\text { skimmer })\end{array}$ & 0.41 & $<0.4$ & 193 \\
\hline $\mathrm{Zn}$ & FAAS & $\begin{array}{l}\text { 5-amino-1,3,4- } \\
\text { thiadiazole-2-thiol } \\
\text { modified silica gel } \\
\text { preconcentrated }\end{array}$ & n.a. & $6-8$ & 210 \\
\hline
\end{tabular}




\begin{tabular}{|c|c|c|c|c|}
\hline FAAS & $\begin{array}{c}\text { Preconcentrated by } \\
\text { evaporation }\end{array}$ & n.a. & $8-11$ & 210 \\
\hline FAAS & $\begin{array}{c}\text { Preconcentrated by } \\
\text { 2,5-dimercapto- } \\
\text { 1,3,4-thiadiazole }\end{array}$ & n.a. & $3-4.5$ & 211 \\
\hline FAAS & $\begin{array}{l}\text { Preconcentrated } \\
\text { with 2- } \\
\text { aminothiazole } \\
\text { modified silica gel }\end{array}$ & 0.34 & $6.3-8.3$ & 183 \\
\hline ETAAS & EC & n.a. & $7.1-8.1$ & 183 \\
\hline FAAS & $\begin{array}{l}\text { Preconcentration } \\
\text { with } 2,2^{\prime}- \\
\text { dipyridylamine } \\
\text { bonded silica }\end{array}$ & 0.58 & $6-10$ & 180 \\
\hline FAAS & $\begin{array}{c}\text { Preconcentrated by } \\
\text { evaporation }\end{array}$ & n.a. & $8-11$ & 180 \\
\hline FAAS & $\begin{array}{c}\text { EC } \\
\text { Preconcentration } \\
\text { with } N \text {-Acyl-N- } \\
\text { Benzoylthiourea } \\
\text { modified silica gel }\end{array}$ & n.a. & $1.0-2.4$ & 209 \\
\hline $\mathrm{HPCIC}$ & $\mathrm{EC}\left(\mathrm{Zn}^{2+}\right)$ & 2.0 & n.d. & 182 \\
\hline ICP-OES & EC & 0.53 & n.d. & 177 \\
\hline
\end{tabular}




\begin{tabular}{|c|c|c|c|c|}
\hline & $\begin{array}{l}\text { cooled spray } \\
\text { chamber } \\
\text { Zn } 206.200\end{array}$ & & & \\
\hline ICP-OES & $\begin{array}{c}\text { EC } \\
\text { cooled spray } \\
\text { chamber } \\
\text { Zn } 213.856\end{array}$ & 0.60 & n.d. & 177 \\
\hline MCN-ICP-MS & $\begin{array}{c}\text { EC and } Y, \text { Ir and Rh } \\
\text { as IS }\end{array}$ & $0.4-0.6^{1}$ & $14.4-36.1^{2}$ & 190 \\
\hline USN-CD-ICP-OES & EC & 0.3 & n.d. & 197 \\
\hline CRI-ICP-MS & $\begin{array}{c}\text { IS }(\mathrm{Y}) \\
\mathrm{CRI}\left(\mathrm{H}_{2} \text { through }\right. \\
\text { skimmer) }\end{array}$ & 0.26 & $17-400$ & 193 \\
\hline
\end{tabular}

These ranges correspond to minimum and maximum LOD values obtained with the four types of calibration employed by the authors (External calibration and Internal standardization with Ir, Rh and Y).

${ }^{2}$ Concentration values have been obtained employing $\mathrm{Y}$ as internal standard.

ID: Isotopic Dilution; EC: External Calibration; EC (W): External Calibration with water; EC (MM): External calibration with matrix matching.

n.d.: non determined in real samples; n.a.: not available data.

\subsection{Comparison among techniques.}

As it has been previously discussed, several techniques have been employed to quantify metals in bioethanol and fuel ethanol samples. Generally speaking the elemental 
concentration in this kind of samples is very low (Table 6) and, hence, it is necessary to select a sensitive enough technique. For this reason ICP-OES and ICP-MS are widely used ${ }^{10,14,21-}$ $24,31,38,39,42,176,177,184,185,188,190,192-198,202$ because it is possible to carry out the sample analysis without any pre-concentration step. Unfortunately, these techniques are quite sensitive to spectral as well as non-spectral interferences that could be circumvented by applying dedicated approaches. $39,176,177,184,185,195-198,202$ Another technique that has been used widely to determine metals in fuel ethanol is ETAAS ${ }^{179,203-208}$ due to the advantages discussed in previous sections. Meanwhile, techniques such as voltammetry ${ }^{187,213,214}$, chromatographic techniques $^{182}$ or MIP-OES ${ }^{181}$ are less frequently employed.

Figure 6 shows the percentage of studies carried out by each technique for all the elements studied in the literature. This data have been obtained from data collected in Table 6 . The data of Y-axis have been obtained according to Equation 1.

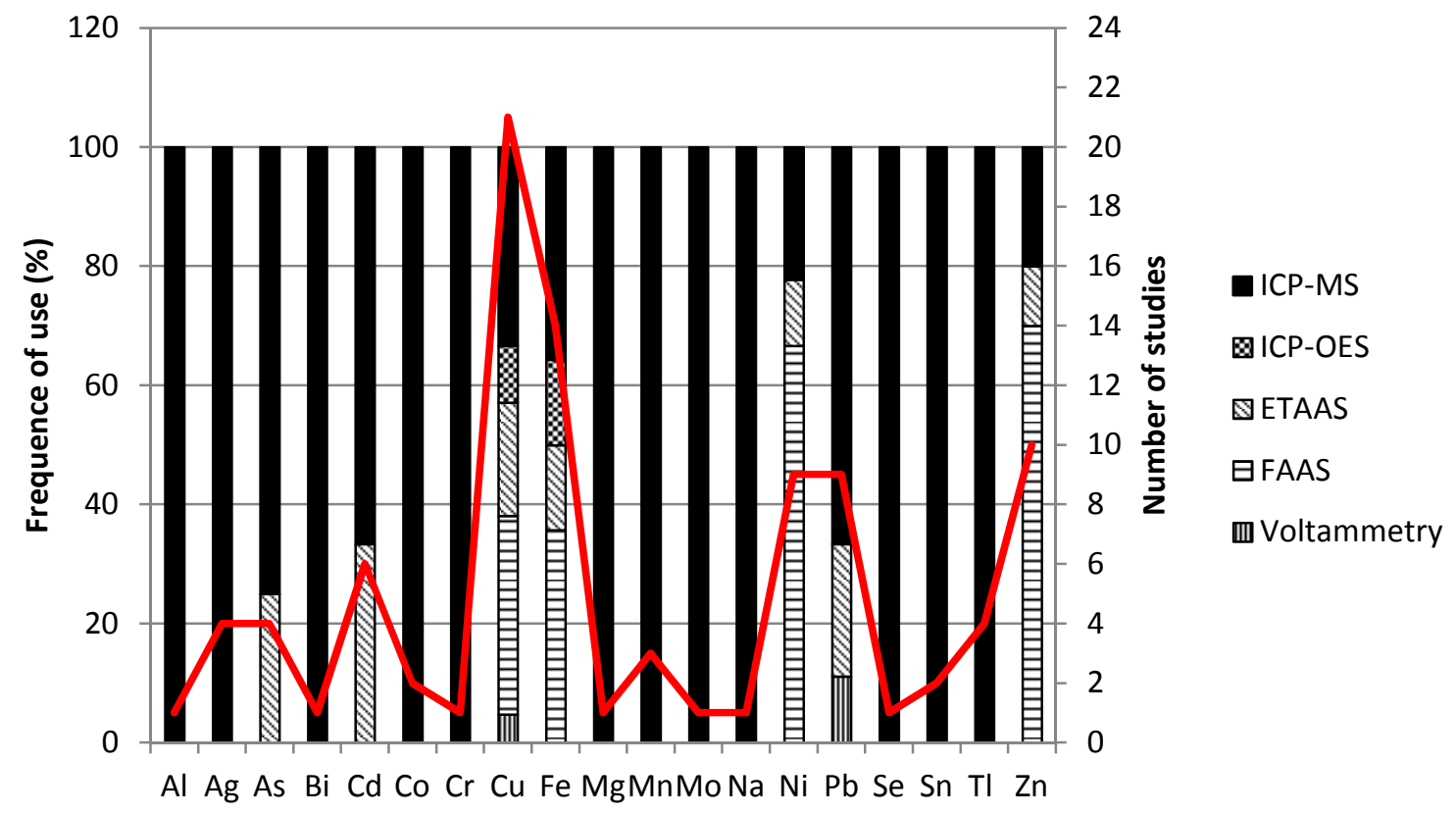

Figure 6. Techniques employed for the determination of several metals in biodiesel samples (bars) and number of studies dealing with the determination of each one of the elements (red line). 
As Figure 6 suggests, ICP-MS is the most widely employed technique. ICP-OES, in turn, has been used for the determination of 7 elements present at concentrations of around a few $\mu \mathrm{g} \mathrm{L} \mathrm{L}^{-1}$. However, because ICP-based techniques are very sensitive to organic solvents ETAAS has been used as a good alternative. On the other hand, FAAS and some chromatographic techniques have been applied to the determination of major elements (Figure 6) in bioethanol and fuel ethanol. Table 7 gathers the existing Standards for the elemental determination in ethanol employed for fuel applications. It is interesting to notice that in some instances, methods such as colorimetry or potentiometry are recommended. As regards ICPOES and ICP-MS these techniques are seldom considered. A similar comment can be made regarding atomic absorption techniques.

Table 7. Standards for the elemental determination in ethanol employed for fuel applications.

\begin{tabular}{|c|c|c|c|}
\hline $\begin{array}{l}\text { Standard } \\
\text { reference }\end{array}$ & Standard title & $\begin{array}{l}\text { Determined } \\
\text { elements }\end{array}$ & Analytical technique \\
\hline EN 15485 & $\begin{array}{l}\text { Ethanol as a blending component for } \\
\text { petrol - Determination of sulfur } \\
\text { content - Wavelength dispersive X- } \\
\text { ray fluorescence spectrometric } \\
\text { method }\end{array}$ & S & WDXRF \\
\hline EN 15486 & $\begin{array}{l}\text { Ethanol as a blending component for } \\
\text { petrol - Determination of sulfur } \\
\text { content - Ultraviolet fluorescence } \\
\text { method }\end{array}$ & S & UVF \\
\hline EN 15487 & Ethanol as a blending component for & $P$ & Colorimetry \\
\hline
\end{tabular}




\begin{tabular}{|c|c|c|c|}
\hline & $\begin{array}{l}\text { petrol - Determination of phosphorus } \\
\text { content - Ammonium molybdate } \\
\text { spectrometric method }\end{array}$ & & \\
\hline EN 15488 & $\begin{array}{l}\text { Ethanol as a blending component for } \\
\text { petrol - Determination of copper } \\
\text { content - Graphite furnace atomic } \\
\text { absorption spectrometric method }\end{array}$ & $\mathrm{Cu}$ & ETAAS \\
\hline EN 15492 & $\begin{array}{l}\text { Ethanol as a blending component for } \\
\text { petrol - Determination of inorganic } \\
\text { chloride and sulfate content - Ion } \\
\text { chromatographic method }\end{array}$ & $\mathrm{Cl}, \mathrm{S}$ & Ionic Chromatography \\
\hline EN 15837 & $\begin{array}{l}\text { Ethanol as a blending component for } \\
\text { petrol - Determination of phosphorus, } \\
\text { copper and sulfur content - Direct } \\
\text { method by inductively coupled } \\
\text { plasma optical emission spectrometry } \\
\text { (ICP OES) }\end{array}$ & $\mathrm{P}, \mathrm{Cu}, \mathrm{S}$ & ICP-OES \\
\hline ASTM D7319 & $\begin{array}{l}\text { Standard Test Method for } \\
\text { Determination of Existent and } \\
\text { Potential Sulfate and Inorganic } \\
\text { Chloride in Fuel Ethanol and Butanol } \\
\text { by Direct Injection Suppressed Ion } \\
\text { Chromatography }\end{array}$ & $\mathrm{Cl}, \mathrm{S}$ & Ionic Chromatography \\
\hline ASTM D7039 & $\begin{array}{l}\text { Standard Test Method for Sulfur in } \\
\text { Gasoline, Diesel Fuel, Jet Fuel, }\end{array}$ & $\mathrm{S}$ & MWDXRF \\
\hline
\end{tabular}




\begin{tabular}{|c|c|c|c|}
\hline & $\begin{array}{l}\text { Kerosine, Biodiesel, Biodiesel } \\
\text { Blends, and Gasoline-Ethanol Blends } \\
\text { by Monochromatic Wavelength } \\
\text { Dispersive X-ray Fluorescence } \\
\text { Spectrometry }\end{array}$ & & \\
\hline ASTM D7328 & $\begin{array}{l}\text { Standard Test Method for } \\
\text { Determination of Existent and } \\
\text { Potential Inorganic Sulfate and Total } \\
\text { Inorganic Chloride in Fuel Ethanol by } \\
\text { Ion Chromatography Using Aqueous } \\
\text { Sample Injection }\end{array}$ & $\mathrm{Cl}, \mathrm{S}$ & Ionic Chromatography \\
\hline ASTM D7318 & $\begin{array}{l}\text { Standard Test Method for Existent } \\
\text { Inorganic Sulfate in Ethanol by } \\
\text { Potentiometric Titration }\end{array}$ & $\mathrm{S}$ & Potentiometry \\
\hline ASTM D5798 & $\begin{array}{l}\text { Standard Specification for Fuel } \\
\text { Ethanol (Ed75-Ed85) for Automotive } \\
\text { Spark-Ignition Engines }\end{array}$ & Speci & \\
\hline ASTM D4806 & $\begin{array}{l}\text { Standard Specification for Denatured } \\
\text { Fuel Ethanol for Blending with } \\
\text { Gasolines for Use as Automotive } \\
\text { Spark-Ignition Engine Fuel }\end{array}$ & \multicolumn{2}{|c|}{ Specifications* } \\
\hline \multicolumn{4}{|c|}{ *These standards refer to : } \\
\hline \multicolumn{2}{|c|}{ ASTM D5453 (S by UVF) } & $S$ & UVF \\
\hline \multicolumn{2}{|c|}{ ASTM D2622 (S by XRF) } & $\mathrm{S}$ & WDXRF \\
\hline \multicolumn{2}{|c|}{ ASTM D5059 (Pb by XRF) } & $\mathrm{Pb}$ & WDXRF \\
\hline
\end{tabular}




\section{Conclusions}

Summarizing the results obtained in the literature, Figure 7 shows the elements found in biofuel samples. Data from Table 3 and Table 6 have been employed. The considered data correspond to 'pure' biodiesel and fuel ethanol samples. It is important to note that metal concentration in blend biodiesel has not been taken into account. Since, there are no clear data regarding the metal concentration in only bioethanol, the results corresponding to fuel ethanol are included in Figure 7. A code indicating the metal content is also applied in order to distinguish major elements from trace elements.

The results concerning biodiesel characterization are more abundant than those corresponding to bioethanol analysis. Thus, in the first case, official directives have been developed so as to assure the quality of the employed fuel. This is in clear constrast with the situation found when bioethanol samples are considered. In that case, the studies provide information about the concentration of metals in the blend corresponding to bioethanol and gasolie (fuel ethanol). As a result, it is difficult to discern among the different sources of metallis species. It is also interesting to notice that there are no data regarding organometallic speciation in this kind of products. Additional data regarding isotopic analysis are also scarce. This information would provide a better insight in the toxic potential of the different fuels. Furthermore, they would also give information about the geographical origin as well as the raw materials employed for production. 


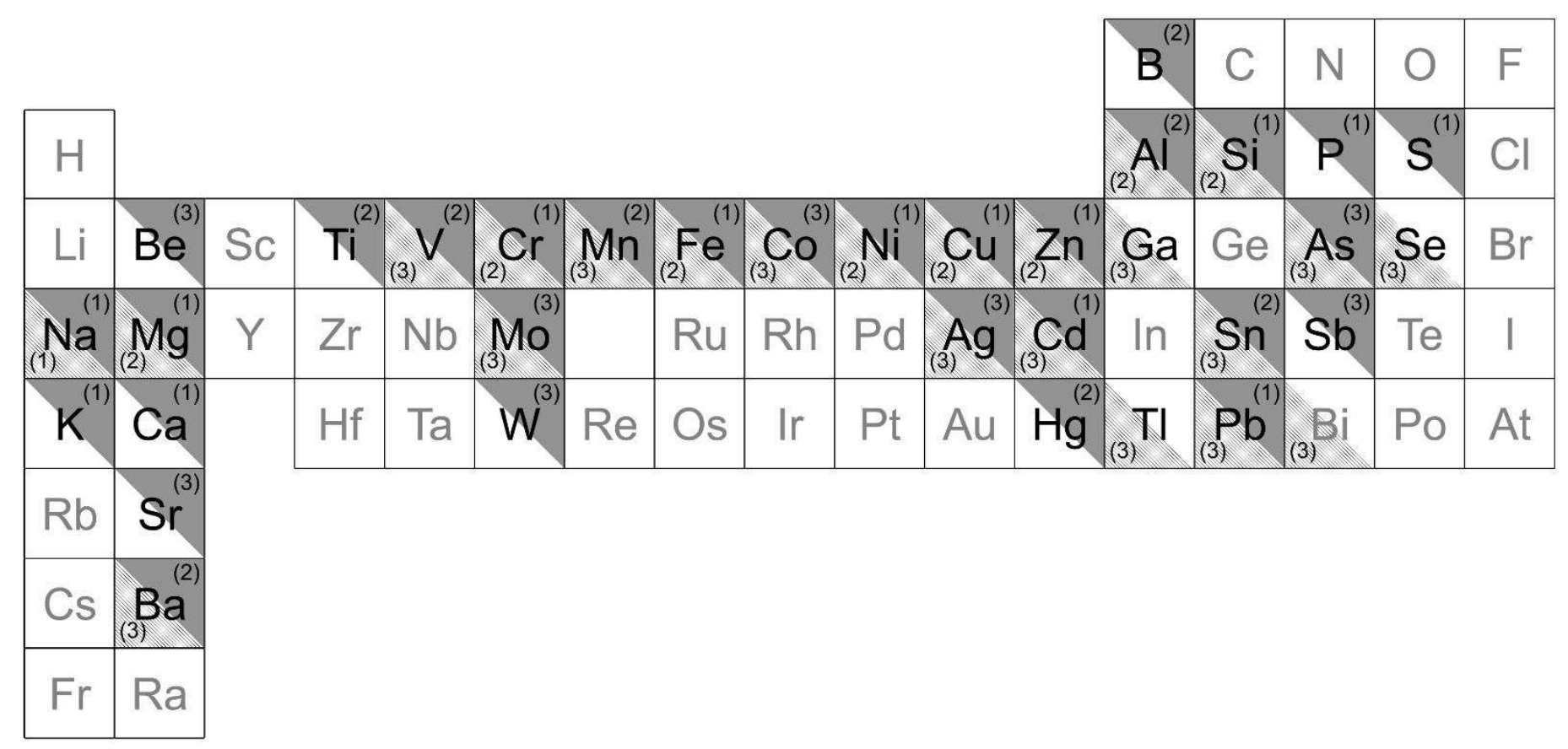

Figure 7. Main elements found in real biodiesel and ethanol fuel samples. : biodiesel; $\quad$ : bioethanol. (1) Present at concentrations on the order of $\mathrm{mg} \mathrm{L}^{-1}$; (2) present at concentrations higher than $10 \mu \mathrm{g} \mathrm{L}^{-1}$ and lower than $1 \mathrm{mg} \mathrm{L}^{-1}$; (3) present at concentrations lower than $10 \mathrm{ng}$ $\mathrm{mL}^{-1}$ 


\begin{tabular}{|c|c|}
\hline Acronym Term & Term \\
\hline AAS & Atomic absorption spectrometry \\
\hline AFE & Anhydrous fuel ethanol \\
\hline ANP & National Agency of Petroleum \\
\hline ASTM & American Society for Testing and Materials \\
\hline ASV & Anodic stripping voltammetry \\
\hline BEC & Background equivalent concentration \\
\hline CA & Continuous aspiration \\
\hline CDA & Chelidamic acid \\
\hline CRI & Collision-reaction interface \\
\hline CV-AFS & $\begin{array}{l}\text { Cold vapour atomic fluorescence } \\
\text { spectroscopy }\end{array}$ \\
\hline ETAAS & $\begin{array}{l}\text { Electrothermal atomic absorption } \\
\text { spectroscopy }\end{array}$ \\
\hline$D_{3,2}$ & Sauter mean diameter \\
\hline$D_{50}$ & $\begin{array}{l}\text { Median of the aerosol volume drop size } \\
\text { distribution }\end{array}$ \\
\hline DCC & dynamic collision cell \\
\hline DPA & \\
\hline DRC & Dynamic reaction cell \\
\hline $\mathrm{EC}(\mathrm{MM})$ & External calibration with matrix matching \\
\hline EC (W) & External calibration with water \\
\hline ETV & Electrothermal vaportization \\
\hline
\end{tabular}




\begin{tabular}{|c|c|}
\hline FAAS & Flame atomic absorption Spectrometry \\
\hline FAEE & Fatty acid ethyl esters \\
\hline FAES & Flame atomic emission spectrometry \\
\hline FAME & Fatty acid methyl esters \\
\hline HFE & hydrated fuel ethanol \\
\hline HR-CS-AAS & $\begin{array}{l}\text { High-resolution continuum source graphite } \\
\text { furnace atomic absorption spectrometry }\end{array}$ \\
\hline IC & Ionic chromatography \\
\hline ICP & Inductively coupled plasma \\
\hline ICP-MS & $\begin{array}{l}\text { Inductively coupled plasma mass } \\
\text { spectrometry }\end{array}$ \\
\hline ICP-OES & $\begin{array}{l}\text { Inductively coupled plasma optical emission } \\
\text { spectrometry }\end{array}$ \\
\hline ICP-QQQ & $\begin{array}{l}\text { Inductively coupled plasma triple } \\
\text { quadrupole }\end{array}$ \\
\hline ID & Isotopic dilution \\
\hline IDA & Iminodiacetic acid \\
\hline LHR & Solid lignin hydrolysate residue \\
\hline LOD & Limit of detection \\
\hline LOQ & Limit of quantitation \\
\hline $\mathrm{MCN}$ & Microconcentric nebulizer \\
\hline MIP-OES & $\begin{array}{l}\text { Microwave-induced plasma optical emission } \\
\text { spectrometry }\end{array}$ \\
\hline
\end{tabular}




\begin{tabular}{|c|c|}
\hline $\mathrm{n}_{\mathrm{e}}$ & Electron number density \\
\hline n.a. & Not available data \\
\hline n.d. & Not determined in real samples \\
\hline ORS & Octopole reaction System \\
\hline PAR & 4-(2-pyridylazo)resorcinol \\
\hline R.F. & Radio frequency \\
\hline RSD & Relative standard deviation \\
\hline SF-ICP-MS & $\begin{array}{l}\text { Sector field inductively coupled plasma } \\
\text { mass spectrometry }\end{array}$ \\
\hline SF-ICP-MS & $\begin{array}{l}\text { sector field inductively coupled plasma mass } \\
\text { spectrometry }\end{array}$ \\
\hline SSF & $\begin{array}{l}\text { Simultaneous saccharification and } \\
\text { fermentation }\end{array}$ \\
\hline TEA & Triethylamine \\
\hline THGA & Transversely heated graphite atomizer \\
\hline TISIS & $\begin{array}{l}\text { Torch Integrated Sample Introduction } \\
\text { System }\end{array}$ \\
\hline TMAH & Tetramethylammonium hydroxide \\
\hline USN-MD-ICP-OES & $\begin{array}{l}\text { Ultrasonic nebulizer and membrane } \\
\text { desolvator inductively coupled plasma } \\
\text { optical emission spectrometry }\end{array}$ \\
\hline UV & Ultraviolet vacuum \\
\hline WCAES & Tungsten coil atomic emission spectrometry \\
\hline
\end{tabular}




\section{Acknowledgements}

The authors would like to thank Dr. Vincent Coupard for his useful comments on biodiesel production.

6. References.

1. H. Habe, T. Shinbo, T. Yamamoto, S. Sato, H. Shimada, and K. Sakaki, J. Japan Pet. Inst., 2013, 56, 414-422.

2. D. Chiche, C. Diverchy, A. C. Lucquin, F. Porcheron, and F. Defoort, Oil Gas Sci. Technol. - Rev. d'IFP Energies Nouv., 2013, 68, 707-723.

3. E. J. dos Santos, A. B. Herrmann, E. S. Chaves, W. W. D. Vechiatto, A. C. Schoemberger, V. L. a. Frescura, and A. J. Curtius, J. Anal. At. Spectrom., 2007, 22, 1300 .

4. M. Edlund, H. Visser, and P. Heitland, J. Anal. At. Spectrom., 2002, 17, 232-235.

5. E. S. Chaves, M. T. C. De Loos-Vollebregt, A. J. Curtius, and F. Vanhaecke, Spectrochim. Acta - Part B At. Spectrosc., 2011, 66, 733.

6. J. Farino and R. F. Browner, Anal. Chem., 1984, 56, 2709-2714.

7. J. L. Todolí, A. Canals, and V. Hernandis, J. Anal. At. Spectrom., 1996, 11, 949-956.

8. B. L. Sharp, J. Anal. At. Spectrom., 1988, 3, 613-652.

9. R. Sánchez, J. L. Todolí, C. P. Lienemann, and J. M. Mermet, J. Anal. At. Spectrom., 2010, 25, 178-185.

10. R. I. McCrindle and C. J. Rademeyer, J. Anal. At. Spectrom., 1994, 9, 1087-1091.

11. L. Ebdon, E. H. Evans, and N. W. Barnett, J. Anal. At. Spectrom., 1989, 4, 505-508.

12. A. W. Boorn, M. S. Cresser, and R. F. Browner, Spectrochim. Acta Part B At. Spectrosc., 1980, 35, 823-832.

13. A. C. Lazar and P. B. Farnsworth, Anal. Chem., 1997, 69, 3921-3929.

14. R. I. McCrindle and C. J. Rademeyer, J. Anal. At. Spectrom., 1996, 11, 437-444.

15. J.-L. Todoli and J.-M. Mermet, J. Anal. At. Spectrom., 2002, 17, 211-218.

16. E. Paredes, S. E. Maestre, J. L. Todoli, and J. L. Todolí, Spectrochim. Acta - Part B At. Spectrosc., 2006, 61, 326. 
17. A. W. Boorn and R. F. Browner, Anal. Chem., 1982, 54, 1402-1410.

18. R. F. Browner, A. Canals, and V. Hernandis, Spectrochim. Acta Part B-Atomic Spectrosc., 1992, 47, 659-673.

19. C. K. Pan, G. X. Zhu, and R. F. Browner, J. Anal. At. Spectrom., 1990, 5, 537-542.

20. D. G. Weir and M. W. Blades, J. Anal. At. Spectrom., 1996, 11, 43-52.

21. D. G. Weir and M. W. Blades, J. Anal. At. Spectrom., 1994, 9, 1311-1322.

22. R. I. McCrindle and C. J. Rademeyer, Anal. Bioanal. Chem., 1996, 355, 264-6.

23. R. I. McCrindle and C. J. Rademeyer, J. Anal. At. Spectrom., 1995, 10, 399-404.

24. D. G. Weir and M. W. Blades, J. Anal. At. Spectrom., 1996, 11, 1011-1018.

25. G. Kreuning and F. Maessen, Spectrochim. Acta Part B-Atomic Spectrosc., 1989, 44, 367-384.

26. M. W. Blades and B. L. Caughlin, Spectrochim. Acta Part B At. Spectrosc., 1985, 40, $579-591$.

27. D. G. Weir and M. W. Blades, J. Anal. At. Spectrom., 1994, 9, 1323-1334.

28. P. W. J. M. Boumans and M. C. Lux-Steiner, Spectrochim. Acta Part B At. Spectrosc., 1982, 37, 97-126.

29. G. Kreuning and F. J. M. J. Maessen, Spectrochim. Acta Part B At. Spectrosc., 1987, 42, 677-688.

30. V. M. Goldfarb and H. V. Goldfarb, Spectrochim. Acta Part B At. Spectrosc., 1985, 40, 177-194.

31. H. Benli, Spectrochim. Acta Part B At. Spectrosc., 1983, 38, 81-91.

32. K. Visser, F. M. Hamm, and P. B. Zeeman, Appl. Spectrosc., 1976, 30, 34-38.

33. Y. Q. Tang and C. Trassy, Spectrochim. Acta Part B At. Spectrosc., 1986, 41, 143-150.

34. P. E. Walters and C. A. Barnardt, Spectrochim. Acta Part B At. Spectrosc., 1988, 43, 325-337.

35. M. Murillo and J. M. Mermet, Spectrochim. Acta Part B At. Spectrosc., 1989, 44, 359366.

36. L. Ebdon and P. Goodall, J. Anal. At. Spectrom., 1992, 7, 1111-1116.

37. S. J. Kumar and S. Gangadharan, J. Anal. At. Spectrom., 1999, 14, 967-971. 
38. E. McCurdy and D. Potter, Agil. Technol., 2002, 5988-6190E.

39. T. D. Saint ${ }^{\prime}$ Pierre, L. Tormen, V. L. Frescura, and A. J. Curtius, J. Anal. At. Spectrom., 2006, 21, 1340.

40. P. C. Hauser and M. W. Blades, Appl. Spectrosc., 1988, 42, 595-598.

41. J. Goossens, F. Vanhaecke, L. Moens, and R. Dams, Anal. Chim. Acta, 1993, 280, 137-143.

42. V. L. Dressler, D. Pozebon, and A. J. Curtius, Anal. Chim. Acta, 1999, 379, 175.

43. R. M. Olivas, C. R. Quetel, and O. F. X. Donard, J. Anal. At. Spectrom., 1995, 10, 865870.

44. A. S. Al-Ammar, E. Reitznerová, and R. M. Barnes, Spectrochim. Acta Part B At. Spectrosc., 1999, 54, 1813-1820.

45. Z. Hu, S. Hu, S. Gao, Y. Liu, and S. Lin, Spectrochim. Acta - Part B At. Spectrosc., 2004, 59, 1463.

46. S. C. K. Shum, S. K. Johnson, H. M. Pang, and R. S. Houk, Appl. Spectrosc., 1993, 47, $575-585$.

47. F. Vanhaecke, R. Dams, and C. Vandecasteele, J. Anal. At. Spectrom., 1993, 8, 433438.

48. H. P. Longerich, J. Anal. At. Spectrom., 1989, 4, 665.

49. E. H. Evans and L. Ebdon, J. Anal. At. Spectrom., 1990, 5, 425-430.

50. G. D. Woods and F. I. Fryer, Anal. Bioanal. Chem., 2007, 389, 753-761.

51. European Parliament \& Council, Directive 2009/28/EC on the promotion of the use of energy from renewable sources and amending and subsequently repealing Directives 2001/77/EC and 2003/30/EC, .

52. D. E. López, G. G. J. James, D. A. Bruce, and E. Lotero, Appl. Catal. A Gen., 2005, 295, 97-105.

53. Y. C. Sharma, B. Singh, and S. N. Upadhyay, Fuel, 2008, 87, 2355-2373.

54. M. Zabeti, W. M. A. W. Daud, and M. K. Aroua, Appl. Catal. a-General, 2009, 366, 154-159.

55. D. Y. C. Leung, X. Wu, and M. K. H. Leung, Appl. Energy, 2010, 87, 1083-1095.

56. F. A. C. Amorim, B. Welz, A. C. S. Costa, F. G. Lepric, M. G. R. Vale, and S. L. C. Ferreira, Talanta, 2007, 72, 349-359. 
57. S. P. Singh and D. Singh, Renew. Sustain. Energy Rev., 2010, 14, 200-216.

58. H. Fukuda, A. Kondo, and H. Noda, J. Biosci. Bioeng., 2001, 92, 405-416.

59. E. S. Chaves, E. J. dos Santos, R. G. O. Araujo, J. V. Oliveira, V. L. a. Frescura, and A. J. Curtius, Microchem. J., 2010, 96, 71-76.

60. E. Paredes, S. Z. Can, and C. R. Quétel, Fuel, 2014, 123, 248-255.

61. E. Pillay, M. Elkadi, S. C. Fok, S. Stephen, J. Manuel, M. Z. Khan, and S. Unnithan, Fuel, 2012, 97, 385-389.

62. J. M. Marchetti, V. U. Miguel, and A. F. Errazu, Renew. Sustain. Energy Rev., 2007, 11, 1300-1311.

63. L. C. Meher, V. S. S. Dharmagadda, and S. N. Naik, Bioresour. Technol., 2006, 97, 1392-1397.

64. T. Furusawa, F. Kurayama, H. Handa, R. Kadota, M. Sato, and N. Suzuki, Appl. Catal. A Gen., 2014, 475, 69-75.

65. F. Ma and M. A. Hanna, Bioresour. Technol., 1999, 70, 1-15.

66. T. D. Saint'Pierre, L. F. Dias, S. M. Maia, and A. J. Curtius, Spectrochim. Acta Part BAtomic Spectrosc., 2004, 59, 551-558.

67. M. L. Granados, M. D. Z. Poves, D. M. Alonso, R. Mariscal, F. C. Galisteo, R. Moreno-Tost, J. Santamaría, and J. L. G. Fierro, Appl. Catal. B Environ., 2007, 73, $317-326$.

68. A. Kawashima, K. Matsubara, and K. Honda, Bioresour. Technol., 2009, 100, 696700 .

69. X. Liu, H. He, Y. Wang, S. Zhu, and X. Piao, Fuel, 2008, 87, 216-221.

70. N. Santiago-Torres, I. C. Romero-Ibarra, and H. Pfeiffer, Fuel Process. Technol., 2014, 120, 34-39.

71. W. Xie and L. Zhao, Energy Convers. Manag., 2014, 79, 34-42.

72. W. Liu, P. Yin, X. Liu, W. Chen, H. Chen, C. Liu, R. Qu, and Q. Xu, Energy Convers. Manag., 2013, 76, 1009-1014.

73. W. Xie and L. Zhao, Energy Convers. Manag., 2013, 76, 55-62.

74. M. Li, Y. Zheng, Y. Chen, and X. Zhu, Bioresour. Technol., 2014, 154, 345-348.

75. M. Farooq, A. Ramli, and D. Subbarao, J. Clean. Prod., 2013, 59, 131-140. 
76. Y.-L. Meng, S.-J. Tian, S.-F. Li, B.-Y. Wang, and M.-H. Zhang, Bioresour. Technol., 2013, 136, 730-734.

77. A. Islam, Y. H. Taufiq-Yap, C.-M. Chu, E.-S. Chan, and P. Ravindra, Process Saf. Environ. Prot., 2013, 91, 131-144.

78. S. Semwal, A. K. Arora, R. P. Badoni, and D. K. Tuli, Bioresour. Technol, 2011, 102, 2151-2161.

79. A. K. Endalew, Y. Kiros, and R. Zanzi, Biomass and Bioenergy, 2011, 35, 3787-3809.

80. M. Takase, M. Zhang, W. Feng, Y. Chen, T. Zhao, S. J. Cobbina, L. Yang, and X. Wu, Energy Convers. Manag., 2014, 80, 117-125.

81. J. M. Dias, M. C. M. Alvim-Ferraz, M. F. Almeida, J. D. M. Díaz, M. S. Polo, and J. R. Utrilla, Fuel, 2012, 94, 418-425.

82. B.-X. Peng, Q. Shu, J.-F. Wang, G.-R. Wang, D.-Z. Wang, and M.-H. Han, Process Saf. Environ. Prot., 2008, 86, 441-447.

83. D. M. Alonso, R. Mariscal, M. L. Granados, and P. Maireles-Torres, Catal. Today, 2009, 143, 167-171.

84. P.-L. Boey, G. P. Maniam, and S. A. Hamid, Chem. Eng. J., 2011, 168, 15-22.

85. H. Wu, J. Zhang, Q. Wei, J. Zheng, and J. Zhang, Fuel Process. Technol., 2013, 109, $13-18$.

86. C. S. MacLeod, A. P. Harvey, A. F. Lee, and K. Wilson, Chem. Eng. J., 2008, 135, 6370.

87. A. P. S. Chouhan and A. K. Sarma, Renew. Sustain. Energy Rev., 2011, 15, 43784399.

88. S. Yan, M. Kim, S. O. Salley, and K. Y. S. Ng, Appl. Catal. A Gen., 2009, 360, 163170.

89. Commission of the European Communities, EC (2006) Communication from the Commission: an EU strategy for biofuels, Brussels, 2006.

90. A. de Jesus, M. M. Silva, and M. G. R. Vale, Talanta, 2008, 74, 1378-84.

91. F. A. Lobo, D. Goveia, A. P. Oliveira, L. P. C. Romão, L. F. Fraceto, N. L. D. Filho, and A. H. Rosa, Fuel, 2011, 90, 142-146.

92. A. P. de Oliveira, R. D. Villa, K. C. P. Antunes, A. de Magalhães, and E. C. e Silva, Fuel, 2009, 88, 764-766. 
93. E. S. Chaves, F. G. Lepri, J. S. a. Silva, D. P. C. de Quadros, T. D. Saint'Pierre, A. J. Curtius, and E.S. Chaves; F.G. Lepri; J.S.A: Silva; P.C. Quadros; T.D. Saint'pierre; A.J. Curius, J. Environ. Monit., 2008, 10, 1211.

94. J.S.A. Silva; E.S. Chaves; E.J. Santos; T.D. Saint'pierre; V.L. Frescura; A.J. Curtius, J. S. A. Silva, E. S. Chaves, and A. J. Curtius, 2010, 21, 620-626.

95. P. R. Aranda, P. H. Pacheco, R. A. Olsina, L. D. Martinez, and R. A. Gil, J. Anal. At. Spectrom., 2009, 24, 1441.

96. J. Paligova, L. Joríkova, and J. Cvengros, 2008, 1991-1996.

97. G. Knothe, Fuel Process. Technol., 2007, 88, 669-677.

98. G. Knothe and R. O. Dunn, J. Am. Oil Chem. Soc., 2003, 80, 1021-1026.

99. A. Sarin, R. Arora, N. P. Singh, M. Sharma, and R. K. Malhotra, Energy, 2009, 34, $1271-1275$.

100. European Committee for Standardization, UNE-EN 14112:2003: Fat and oil derivatives. Fatty Acid Methyl Esters (FAME). Determination of oxidation stability (accelerated oxidation test), 2003.

101. European Committee for Standardization, UNE-EN 14214:2013: Liquid petroleum products - Fatty acid methyl esters (FAME) for use in diesel engines and heating applications - Requirements and test methods, 2013.

102. American Society for Testing and Materials (A.S.T.M.), ASTM D6751 - 12: Standard Specification for Biodiesel Fuel Blend Stock (B100) for Middle Distillate Fuels, 2012.

103. A. Gonzálvez, M. E. Ghanjaoui, M. El Rhazi, and M. de la Guardia, Food Sci. Technol. Int., 2010, 16, 65-71.

104. F. G. Lepri, E. S. Chaves, M. A. Vieira, A. S. Ribeiro, A. J. Curtius, L. C. C. De Oliveira, and R. C. De Campos, Appl. Spectrosc. Rev., 2011, 46, 175.

105. M. D. G. A. Korn, D. S. S. dos Santos, B. Welz, M. G. R. Vale, A. P. Teixeira, D. D. C. Lima, S. L. C. Ferreira, M. das Graças Andrade Korn, D. de Castro Lima, and D. S. S. Dos Santos, Talanta, 2007, 73, 1-11.

106. A. I. Barros, A. P. de Oliveira, M. R. L. de Magalhães, and R. D. Villa, Fuel, 2012, 93, 381-384.

107. M. Ghisi, E. S. Chaves, D. P. C. Quadros, E. P. Marques, A. J. Curtius, and A. L. B. Marques, Microchem. J., 2011, 98, 62.

108. F. A. Lobo, D. Goveia, A. P. de Oliveira, E. R. Pereira-Filho, L. F. Fraceto, N. L. D. Filho, and A. H. Rosa, Fuel, 2009, 88, 1907-1914. 
109. F. H. Lyra, M. T. W. D. Carneiro, G. P. Brandão, H. M. Pessoa, and E. V. de Castro, Microchem. J., 2010, 96, 180-185.

110. D. P. C. Quadros, M. Rau, M. Idrees, E. S. Chaves, A. J. Curtius, and D. L. G. Borges, Spectrochim. Acta Part B At. Spectrosc., 2011, 66, 373-377.

111. R. S. Amais, E. E. Garcia, M. R. Monteiro, A. R. A. Nogueira, and J. A. Nóbrega, Microchem. J., 2010, 96, 146-150.

112. European Committee for Standardization, UNE-EN 14538:2006: Fat and oil derivatives - Fatty acid methyl ester (FAME) - Determination of $\mathrm{Ca}, \mathrm{K}, \mathrm{Mg}$ and $\mathrm{Na}$ content by optical emission spectral analysis with inductively coupled plasma (ICP OES), 2006.

113. European Committee for Standardization, UNE EN 14107: 2003: Fat and oil derivatives. Fatty Acid Methyl Esters (FAME). Determination of phosphorus content by inductively coupled plasma (ICP) emission spectrometry, 2003.

114. Leeman-Labs, Determination of Trace Elements in Biodiesel Feedstocks using Inductively Coupled Plasma Optical Emission Spectrometry, .

115. Leeman-Labs, The Determination of Phosphorous, Sulfur, Sodium, Potassium, Calcium and Magnesium in Biodiesel using the Teledyne FuelPro, .

116. Z. A. Grosser, L. J. Davidowski, and P. Wee, The analysis of biodiesel for inorganic contaminants, including sulfur, by ICP-OES, Perkin Elmer Instruments, 2009.

117. R. Knoll and M. Knopp, Phosphorus, calcium and magnesium analysis of soybean oilfeedstock for biodiesel production using the optima Inductively Coupled Plasma Optical Emission spectrometrer, 2007.

118. P. Sarojam, Quality control of biofuels using a Inductively Copupled Plasma Optical Emission spectrophotometer (ICP-OES) for metals determination, 2009.

119. D. Johnson, Determination of metals in oils by ICP-AES, 1993, vol. ICP-13.

120. R. Sánchez, J. L. Todolí, C.-P. Lienemann, and J.-M. Mermet, Spectrochim. Acta Part B At. Spectrosc., 2013, 88, 104-126.

121. T. L. Thiem and J. D. Watson, Microchem. J., 1997, 57, 245-250.

122. J. L. Burguera and M. Burguera, Talanta, 2004, 64, 1099-1108.

123. R. M. de Souza, L. G. Leocádio, and C. L. P. da Silveira, Anal. Lett., 2008, 41, 16151622.

124. C. G. Young, R. S. Amais, D. Schiavo, E. E. Garcia, J. A. Nóbrega, and B. T. Jones, Talanta, 2011, 84, 995-9. 
125. M. T. Lisboa, C. D. Clasen, D. C. de S. Vellar, E. Q. Oreste, T. D. Saint'Pierre, A. S. Ribeiro, and M. A. Vieira, J. Braz. Chem. Soc., 2014, 25, 143-151.

126. M. G. A. Korn, D. C. M. B. Santos, M. A. B. Guida, I. S. Barbosa, M. L. C. Passos, M. L. M. F. S. Saraiva, and J. L. F. C. Lima, J. Braz. Chem. Soc., 2010, 21, 2278-2284.

127. J. L. Todolí and J. M. Mermet, Trac-Trends Anal. Chem., 2005, 24, 107-116.

128. J. R. de Souza, E. F. dos Santos, C. B. Duyck, and T. D. Saint'Pierre, Spectrochim. Acta Part B At. Spectrosc., 2011, 66, 356-361.

129. M. Bauer and J. A. C. Broekaert, Spectrochim. Acta Part B At. Spectrosc., 2007, 62, $145-154$.

130. M. Bauer and J. A. C. Broekaert, J. Anal. At. Spectrom., 2008, 23, 479-486.

131. M. A. Aguirre, N. Kovachev, M. Hidalgo, and A. Canals, J. Anal. At. Spectrom., 2012, 27, 2102-2110.

132. R. Sanchez, J. L. Todoli, C.-P. Lienemann, J.-M. Mermet, R. Sánchez, and J. L. Todolí, J. Anal. At. Spectrom., 2012, 27, 937.

133. R. Sanchez, C. Sanchez, J. L. Todoli, C.-P. Lienemann, and J.-M. Mermet, J. Anal. At. Spectrom., 2014, 29, 242-248.

134. R. I. Botto, J. J. Zhu, and O. N. Cetac Technol Inc, in 1994 Winter Conference on Plasma Spectrochemistry, Royal Soc Chemistry, San Diego, Ca, 1994, vol. 9, pp. 905912.

135. R. I. Botto, J. J. Zhu, and O. N. Cetac Technol Inc, in 1996 Winter Conference on Plasma Spectrochemistry, Royal Soc Chemistry, Ft Lauderdale, Fl, 1996, vol. 11, pp. 675-681.

136. R. Wennrich; A. Mroczek; K. Dittrich; G. Werner, R. Wennrich, A. Mroczek, K. Dittrich, and G. Werner, Fresenius. J. Anal. Chem., 1995, 352, 461-469.

137. M. Aramendia, M. Resano, and F. Vanhaecke, Anal. Chim. Acta, 2009, 648, 23-44.

138. S. M. Maia, M. G. R. Vale, B. Welz, and A. J. Jose, Spectrochim. Acta - Part B At. Spectrosc., 2001, 56, 1263-1275.

139. G. L. Donati, R. S. Amais, and J. A. Nobrega, J. Anal. At. Spectrom., 2013, 28, 280287.

140. T. D. Saint'Pierre, L. F. Dias, D. Pozebon, R. Q. Aucelio, A. J. Curtius, and B. Welz, Spectrochim. Acta Part B-Atomic Spectrosc., 2002, 57, 1991-2001.

141. R. S. Amais, S. E. Long, J. A. Nóbrega, and S. J. Christopher, Anal. Chim. Acta, 2014, 806, 91-96. 
142. L. Balcaen, G. Woods, M. Resano, and F. Vanhaecke, J. Anal. At. Spectrom., 2013, 28, 33-39.

143. J. V Sokolnikova, I. E. Vasilyeva, and V. I. Menshikov, Spectrochim. Acta Part B At. Spectrosc., 2003, 58, 387-391.

144. E. S. Chaves, T. D. Saint'Pierre, E. J. Dos Santos, L. Tormen, V. L. A. F. Bascuñan, and A. J. Curtius, J. Braz. Chem. Soc., 2008, 19, 856.

145. L. C. C. de Oliveira, M. A. Vieira, A. S. Ribeiro, P. M. Baptista, R. A. Gonsalves, and R. C. de Campos, J. Braz. Chem. Soc., 2012, 23, 1400-1408.

146. European Committee for Standardization, UNE-EN 14108:2003: Fat and oil derivatives. Fatty Acid Methyl Esters (FAME). Determination of sodium content by atomic absorption spectrometry, 2003.

147. European Committee for Standardization, UNE-EN 14109:2003: Fat and oil derivatives. Fatty Acid Methyl Esters (FAME). Determination of potasium content by atomic absorption spectrometry, 2003.

148. M. R. L. de Magalhães, A. I. Barros, A. P. de Oliveira, A. da Silva, and R. D. Villa, Curr. Anal. Chem., 2014, 10, 166-171.

149. R. S. Amais, E. E. Garcia, M. R. Monteiro, and J. A. Nóbrega, Fuel, 2012, 93, 167171.

150. R. E. Santelli, M. A. Bezerra, A. S. Freire, E. P. Oliveira, and M. D. B. de Carvalho, Fuel, 2008, 87, 1617-1622.

151. P. R. Aranda, J. A. Gásquez, R. A. Olsina, L. D. Martinez, and R. A. Gil, Talanta, 2012, 101, 353-356.

152. A. de Jesus, A. V. Zmozinski, I. C. F. Damin, M. M. Silva, and M. G. R. Vale, Spectrochim. Acta Part B At. Spectrosc., 2012, 71-72, 86-91.

153. G. P. Brandao, R. C. de Campos, E. V. R. de Castro, and H. C. de Jesus, Spectrochim. Acta Part B-Atomic Spectrosc., 2008, 63, 880-884.

154. R. J. Cassella, B. Barbosa, R. E. Santelli, and A. T. Rangel, Anal. Bioanal. Chem., 2004, 379, 66-71.

155. E. Becker, R. T. Rampazzo, M. B. Dessuy, M. G. R. Vale, M. M. da Silva, B. Welz, and D. A. Katskov, Spectrochim. Acta Part B At. Spectrosc., 2011, 66, 345-351.

156. F. H. Lyra, M. Carneiro, G. P. Brandao, H. M. Pessoa, E. V. R. de Castro, F. Henrique Lyra, M. T. Weitzel Dias Carneiro, G. Pedrini Brandao, and H. Moura Pessoa, J. Anal. At. Spectrom., 2009, 24, 1262-1266.

157. F. G. Lepri, M. B. Dessuy, M. G. R. Vale, D. L. G. Borges, B. Welz, and U. Heitmann, Spectrochim. Acta Part B At. Spectrosc., 2006, 61, 934-944. 
158. R. C. De Campos, C. L. T. Correia, F. Vieira, T. D. Saint'Pierre, A. C. Oliveira, and R. Gonçalves, Spectrochim. Acta - Part B At. Spectrosc., 2011, 66, 352.

159. R. S. Amais, G. L. Donati, D. Schiavo, and J. A. Nóbrega, Microchem. J., 2013, 106, 318-322.

160. L. B. de Caland, E. L. C. Silveira, and M. Tubino, Anal. Chim. Acta, 2012, 718, 116 20 .

161. Y. Zhang, P. Thepsithar, X. Jiang, and J. H. Tay, Ind. Crops Prod., 2013, 44, 459-464.

162. M. Piovezan, A. C. O. Costa, A. V. Jager, M. A. L. de Oliveira, and G. A. Micke, Anal. Chim. Acta, 2010, 673, 200-205.

163. T. Nogueira and C. L. Do Lago, Microchem. J., 2011, 99, 267-272.

164. T. R. C. Zezza, M. de Souza Castilho, and N. R. Stradiotto, Fuel, 2012, 95, 15-18.

165. L. C. Martiniano, V. R. Abrantes, S. Y. Neto, E. P. Marques, T. C. O. Fonseca, L. L. Paim, A. G. Souza, N. R. Stradiotto, R. Q. Aucélio, G. H. R. Cavalcante, and A. L. B. Marques, Fuel, 2013, 103, 1164-1167.

166. L. Pinto and S. G. Lemos, Microchem. J., 2013, 110, 417-424.

167. G. C. Sedenho, L. L. Paim, and N. R. Stradiotto, Anal. Methods, 2013, 5, 4145-4151.

168. M. de Souza Castilho and N. R. Stradiotto, Talanta, 2008, 74, 1630-1634.

169. J. M. S. Almeida, R. M. Dornellas, S. Yotsumoto-Neto, M. Ghisi, J. G. C. Furtado, E. P. Marques, R. Q. Aucélio, and A. L. B. Marques, Fuel, 2014, 115, 658-665.

170. S. E. Dancsak, S. G. Silva, J. A. Nóbrega, B. T. Jones, and G. L. Donati, Anal. Chim. Acta, 2014, 806, 85-90.

171. American Society for Testing and Materials (ASTM), ASTM D6751 - 12: Standard Specification for Biodiesel Fuel Blend Stock (B100) for Middle Distillate Fuels, 2012.

172. T. Wang, X. Jia, and J. Wu, J. Pharm. Biomed. Anal., 2003, 33, 639-646.

173. C. P. Lienemann, S. Dreyfus, C. Pecheyran, and O. F. X. Donard, Oil Gas Sci. Technol. L Inst. Fr. Du Pet., 2007, 62, 69-77.

174. G. M. Walker, Bioethanol: Science and technology of fuel alcohol, Ventus Publishing ApS, 2010.

175. F. Monot, A. Margeot, B. Hahn-Hägerdal, J. Lindstedt, and R. Slade, Oil Gas Sci. Technol. - Rev. d'IFP Energies Nouv., 2013, 68, 693-705.

176. M. Cassap, I. C. P. A. Specialist, T. F. Scientific, and S. Instruments, . 
177. A. Cosnier, S. Lebouil, S. Vélasquez, and H. J. Yvon, ICP At. Emiss. Spectrosc.

178. F. Rosillo-Calle and A. Walter, Energy Sustain. Dev., 2006, 10, 20-32.

179. L. N. Santos, J. A. G. Neto, and N. M. Caldas, Fuel, 2012, 99, 9-12.

180. E. G. Vieira, I. V Soares, N. L. Dias Filho, N. C. da Silva, E. F. Garcia, A. C. Bastos, S. D. Perujo, T. T. Ferreira, A. H. Rosa, and L. F. Fraceto, J. Colloid Interface Sci., 2013, 391, 116-24.

181. G. L. Donati, R. S. Amais, D. Schiavo, and J. a. Nóbrega, J. Anal. At. Spectrom., 2013, 28, 755 .

182. J. C. Dias, L. T. Kubota, P. N. Nesterenko, G. W. Dicinoski, and P. R. Haddad, Anal. Methods, 2010, 2, 1565.

183. P. S. Roldan, I. L. Alcântara, G. R. Castro, J. C. Rocha, C. C. F. Padilha, and P. M. Padilha, Anal. Bioanal. Chem., 2003, 375, 574.

184. T. D. Saint'Pierre, T. D. A. Maranhão, V. L. A. Frescura, and A. J. Curtius, Spectrochim. Acta - Part B At. Spectrosc., 2005, 60, 605.

185. T. D. Saint'Pierre, V. L. A. Frescura, and A. J. Curtius, Talanta, 2006, 68, 957-62.

186. M. F. De Oliveira, A. A. Saczk, L. L. Okumura, A. P. Fernandes, M. De Moraes, and N. R. Stradiotto, Anal. Bioanal. Chem., 2004, 380, 135-40.

187. R. a.a Munoz, L. Angnes, R. Munoz, and L. Angnes, Microchem. J., 2004, 77, $157-$ 162.

188. M. S. Rocha, M. F. Mesko, F. F. Silva, R. C. Sena, M. C. B. Quaresma, T. O. Araújo, and L. a. Reis, J. Anal. At. Spectrom., 2011, 26, 456.

189. V. N. Alves, R. Mosquetta, N. M. M. Coelho, J. N. Bianchin, K. C. Di Pietro Roux, E. Martendal, and E. Carasek, Talanta, 2010, 80, 1133-8.

190. L. Tormen, E. S. Chaves, T. D. Saint'Pierre, V. L. a. Frescura, and A. J. Curtius, J. Anal. At. Spectrom., 2008, 23, 1300.

191. D. B. Taylor and R. E. Synovec, Talanta, 1993, 40, 495-501.

192. B. Huang, J. Yang, A. Pei, X. Zeng, and P. W. J. M. Boumans, Spectrochim. Acta Part B At. Spectrosc., 1991, 46, 407-416.

193. D. R. Neves, R. S. Amais, J. A. Nóbrega, and J. A. G. Neto, Anal. Lett., 2012, 45, 1111-1121.

194. A. Smith, Application Note Improved Accuracy in the Analysis of Precious Metals by ICP-OES, . 
195. R. E. Sturgeon and J. W. Lam, J. Anal. At. Spectrom., 1999, 14, 785-791.

196. J. S. Lee and H. B. Lim, Bull. Korean Chem Soc., 1999, 20, 1040-1044.

197. D. R. Wiederin, R. S. Houk, R. K. Winge, and A. P. D`Silva, Anal. Chem., 1990, 62, 1155-1160.

198. J. A. McLean, M. G. Minnich, L. A. Iacone, and H. Liu, J. Anal. At. Spectrom., 1998, 13, 829-842.

199. E. H. Evans and J. J. Giglio, J. Anal. At. Spectrom., 1993, 8, 1-18.

200. Y. Cheung, G. C.-Y. Chan, and G. M. Hieftje, J. Anal. At. Spectrom., 2013, 28, 241.

201. T. W. May, R. H. Wiedmeyer, and T.W. May; R.H. Wiedmeyer, At. Spectrosc., 1998, 19, 150-155.

202. Y. Kishi, K. Kawabata, H. Shi, and R. Thomas, Spectrosc. (Santa Monica), 2004, 19, 14-23.

203. A. P. De Oliveira, J. A. G. Neto, and M. M. C. Ferreira, 2006, 31, 7-12.

204. A. P. De Oliveira, M. De Moraes, J. A. Gomes Neto, and E. C. Lima, At. Spectrosc., 2002, 23, 190.

205. A. P. De Oliveira, M. De Moraes, J. A. Gomes Neto, and E. C. Lima, At. Spectrosc., 2002, 23, 39.

206. T. Saint'Pierre, R. Q. Aucélio, and A. J. Curtius, Microchem. J., 2003, 75, 59-67.

207. M. B. O. Giacomelli, J. B. B. Da Silva, T. D. Saint'Pierre, A. J. Curtius, and J. B. B. Da Silva, Microchem. J., 2004, 77, 151.

208. T. D. Saint'Pierre, T. D. A. Maranhão, V. L. Frescura, A. J. Curtius, R. Q. Aucélio, T. D. Saint Pierre, T. D. A. Maranhão, V. L. Frescura, A. J. Curtius, R. Q. Aucélio, and T. D. Saint'Pierre, Quim. Nova, 2008, 31, 1626-1630.

209. C. Pesco, E. A. De Campos, C. Maieru, and M. Costa, Mikrochim. Acta, 1997, 232, 229-232.

210. L. A. de M. Gomes, P. de M. Padilha, J. C. Moreira, N. L. D. Filho, Y. Gushikem, L. A. De Melo, P. De Magalhães, J. Celso, and N. L. Dias, 1998, 9, 494-498.

211. P. Lessia, N. L. D. Filhob, C. Moreiraa, J. T. S. Camposa, P. Lessi, N. L. Dias Filho, J. C. Moreira, and J. T. S. Campos, Anal. Chim. Acta, 1996, 327, 183.

212. J. N. Bianchin, E. Martendal, R. Mior, V. N. Alves, C. S. T. Araújo, N. M. M. Coelho, and E. Carasek, Talanta, 2009, 78, 333-6. 
213. J. Motonaka, H. Konishi, S. Ikeda, and N. Tanaka, Bull. Chem. Soc. Jpn., 1986, 59, 737 -740 .

214. A. I. Kamenev and M. A. Kovalenko, J. Anal. Chem., 2000, 55, 594-597.

215. J. C. Dias, L. T. Kubota, P. N. Nesterenko, and P. R. Haddad, Chromatographia, 2012, 75, 867-873. 